\title{
مiخ عمار
}

\section{بحث بعنوان}

" تأثير فيرس كورونا المستجد علي تنفيذ عقود التجارة الدولية وفقاً للاتفاقيات الدولية

والتثريعين المصري والفرنسي "

اعداد د/ منى عمار 
لم يكن لفيرس كورونا المستجد التأثير الأوحد علي الصحة العامة وفقدان الاحبه، بل كان له تأثير قوي ومباشر علي النواحي الاقتصادية والتجارية عالميا من ينها عقود التجارة الدولية المبرمة قبل تفشي الفيرس وانتشارة في ربوع المعمورة ، وهو ما وضع تتفيذ العديد من العقود علي المحك وما يصحب ذلك من تأثير علي علاقة طرفي العقد وبنودة ، وهو

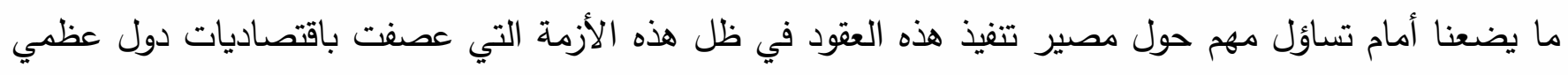
وهوما لا يقل تأثيرًا علي الثركات التجارية التي تعد طرفا في مثل هذا النوع من العقود كوسيلة لسد احتياجات الدولة باعتبارها أحد أهم سبل التبادل التجاري الدولي، وهو ما يضع الدئ الدولة والثركات الوطنية و الأجنبية في مأزق تتفيذها

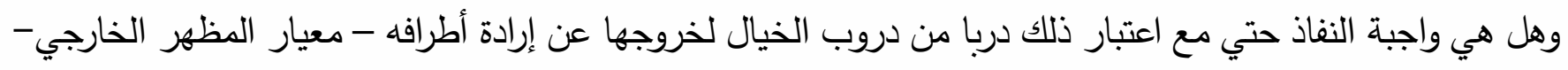

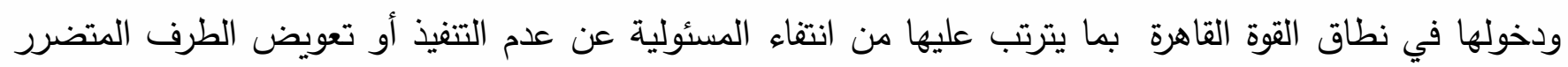

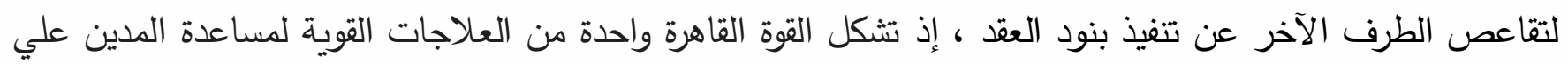

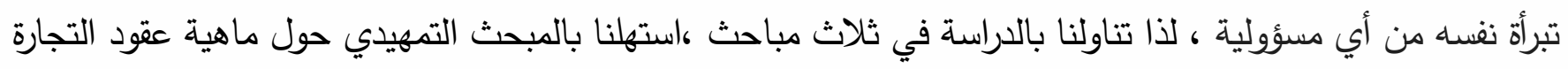
الدولية تلاه مبحثين الأول معنون سبل الإعفاء من المسئولية الناجمة عن الإخلال بتتفيذ عقود التجارة الدولية لانتشار

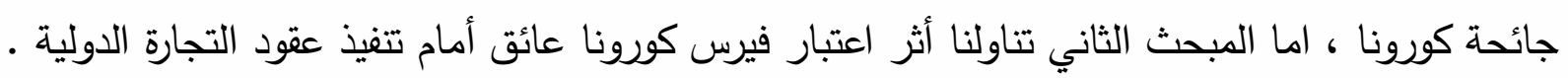

\section{الملخص باللغة الإنجليزية :}

The new Corona virus did not have the only impact on public health and the loss of loved ones, but rather had a strong and direct impact on the economic and commercial aspects globally, including international trade contracts concluded before the outbreak of the virus and its spread throughout the world, which put the implementation of many contracts at stake, and what accompanies that From the impact on the relationship of the two parties to the contract and its clauses, which puts us in front of an important question about the fate of the implementation of these contracts in light of this crisis that afflicted the economies of great countries, which is no less influential on commercial companies that are party to this type of 
contracts as a means to meet the needs of the state as one of the most important means of international trade exchange, Which puts the state and national and foreign companies in the dilemma of their implementation, and is it enforceable, even though this is considered a path of imagination due to its departure from the will of its parties - the criterion of external appearance - and its entry into the scope of force majeure with the consequent absence of responsibility for non-implementation or compensation for the aggrieved party For the other party's failure to implement the terms of the contract, as force majeure constitutes one of the strong remedies to help the debtor absolve himself of any responsibility, therefore, we dealt with the study in three sections, we started with the preliminary study on the nature of international trade contracts, followed by two sections, the first entitled ways to exempt from liability resulting from breaching the implementation of international trade contracts due to the spread of the Corona pandemic, while the second topic dealt with the impact of considering the Corona virus an obstacle to the implementation of international trade contracts. 
لعل تعرض العالم خلال الأعوام المنصرمة للعديد من الفيروسات التي أثرت سلبيا علي اقتصاديات دول عديدة سواء بشكل مباشر - إذا كانت الدول تقع ضمن النطاق الجغرافي الذي تعرض لهجمات الفيرس - أو غير مباشر حال اقتصار انتشارهذه الفيروسات في نطاق دول تتمتع بقوة اقتصادية تجعلها الداعم الأساسي للعديد من اقتصاديات الدول النامية أو الناشئة ومن بينها هذه الدولة ، وهو ما حدث خلال عام 2003 إثر انتشار مرض السارس بدولة الصين الشعبية والذي نتج عنه إصابة 8000 شخص ووفاة774 آخرين ،غير أن هذا الضرر لم يلحق بالاقتصاد الصيني وحسب بل امتد تأثيره إلي العديد من دول العالم وهو ما دفع رجال الاقتصاد إلي ارتباطه بما تعرض له الاقتصاد العالمي من هزة عنيفة، إذ قدر حجم الخسائر الذي مُني بها الاقتصاد العالمي بنحو 50 مليار دولار أمريكي ، ولم يكن هذا هو أخر ما تعرض له الاقتصاد العالمي من أضرار نتيجة انتشار فيرس معدي ففي عام 2015 أدي تفشي مرض متلازمة الثرق الاوسط التنفية الي إصابة 200 شخص ووفاة 38 آخرين وقد نتج عنه خسائر تقدر بنحو 8.5 مليار دولا أمريكي ،وهو ما يؤكد علي التأثير القوي لمثل هذه الفيروسات علي الاقتصاد العالمي إلا أن درجة هذا التأثير يختلف حسب قوة انتشار الفيرس وقدرة الدول علي احتوائه ومنعه من الانتشار من عدمه في الأحوال السابقة إلا أنه لم يتحول علي أي حال إلي جائحة تجتاح العالم ، ولعل ذلك هو ما دفع القضاء إلي عدم اعتبار انتشار الأمراض السابقة أزمات صحية تشكل قوة قاهرة ينتفي علي إثرها المسئولية عن عدم تتفيذ عقود التجارة الدولية كما تحقق بالنسبة لفيرس

كورونا " COVID19" ( ) ( )

إذ نتج عن تفشي مرض فيروس الكورونا(COVID-19) في العالم(2) فاجعة اقتصادية وانسانية لم تقوى أكبر الاقتصاديات علي مواجتها صحيا او اقتصاديا وكأنها حرب فيروسات شرسة - غير مسبوقة وغير متوقعة - لم تقوي

1- ولعل ذلك مرجعه هو ما أن القضاة اعتبر هذه الأمر اض كانت معروفة من قبل ، وكذا مخاطر انتشار ها وآثار ها الصحية ، كما أنها لم تكن مميتة

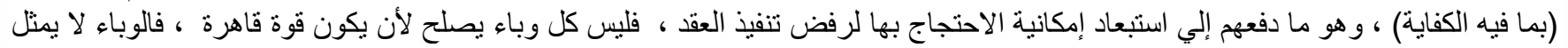

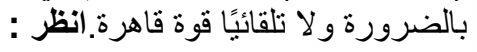

Landivaux (L), Contrats et coronavirus : un cas de force majeure ? Ça dépend... , le 20 Mars 2020,

https://www.dalloz-actualite.fr/node/contrats-et-coronavirus-un-cas-de-force-majeure-ca-

\section{depend\#.XaqmM6gzY2w}

2- ويعرف فيروس كورونا 2 المرتبط بالمنلازمة التنفسية الحادة الثديدة بالإنجليزية Severe acute respiratory syndrome coronavirus

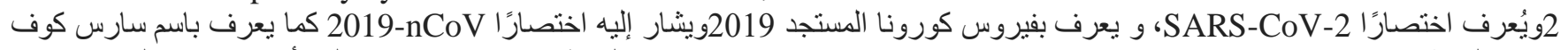

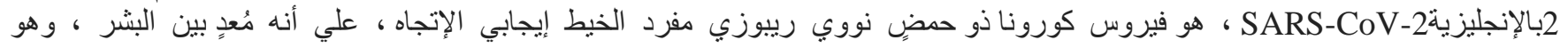


النظم الصحية علي صدها ليمتد فينتشر كالنار في الهشيم لتسقط دولة تلو الأخري إذ بدأمن الصين ثم إيران ثم إيطاليا وإسبانيا لتسقط الحصون المنيعه للعديد من الدول المتقدمة والنامية علي حد سواء ، لتقف الدول جمعاء أمامه عاجزة علي مواجهته لمنعه من مواصلة زحفه الموحش ، فعلي الرغم من امتلاك الدول المتقدمة لنظام صحي قوي مقارنة بناظرتها النامية الا أنها لم تستطع أن تصمد في مواجهته ، وهو ما يبرر اعتبار فيرس كورونا قوة قاهرة ، فنحن بصدد مشهد لم تعهده البشرية علي مشاهدته فالموت يحصد المئات كل يوم واقتصاديات مهددة بالكساد ، مما دفع الخبراء إلي التتبأ بانهيار اقتصاديات دول وصعود دول أخري، لنصبح بصدد تسونامي اقتصادي يقلب اقتصاد العالم رأسا علي عقب ، ولعل ذلك هو ما دفع غرفة التجارة الدولية(3) ، ودول وحكومات مجموعة العشرين برئاسة المملكة العربية السعودية 2020 إلي دعوة الدول وحثها علي اتباع نهج منسق لإدارة الوباء بشكل أفضل في محاولة منها لاحتواء الازمة والخروج منها بأقل خسائر اقتصادية وصحية ممكن (4).

تجدر الإشارة إلي أن العديد من الدول المتقدمة والنامية قد أوقفت الحياة اليومية لشعوبها ليتحول المشهد فيصبح كل فرد في هذه الدول محارب علي خط النارلمواجهة تفشي هذا المرض مما نتج عنه توقف الحياة التجارية والصناعية لدي كافة الدول ، وهو ما يعد مؤشرا خطيرا قد يعصف باقتصاد الدول المنكوبة ، فبفعل هذا الوباء أصبحت دول العالم

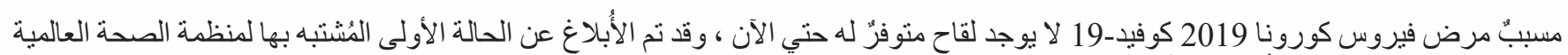

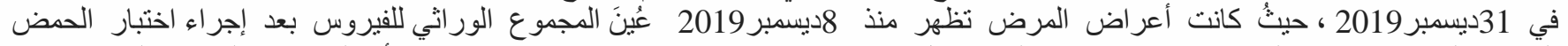

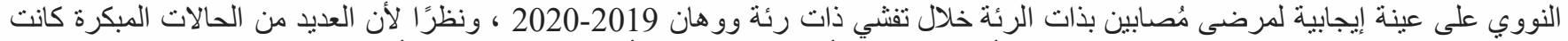

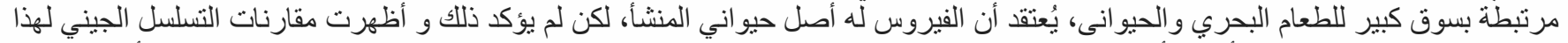

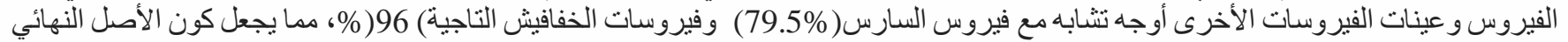

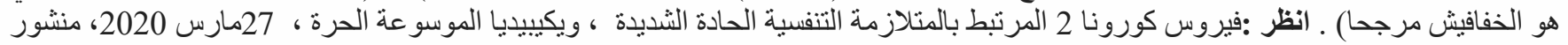
https://ar.wikipedia.org/wiki/\%D9\%81\%D9\%8A\%D8\%B1\%D9\%88\%D8\%B388: علي الموقع التالي

3ـ تعد غرفة التجارة الدولية ( الإلة أكبر منظمة أعمال في العالم ، وتمثل أكثر من 45 مليون شركة في أكثر من 100 دولة، مهنها الأساسية هو

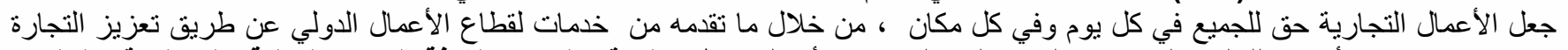

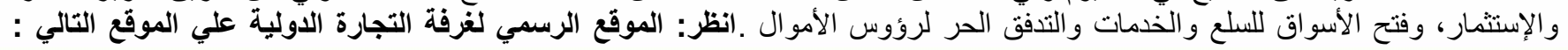

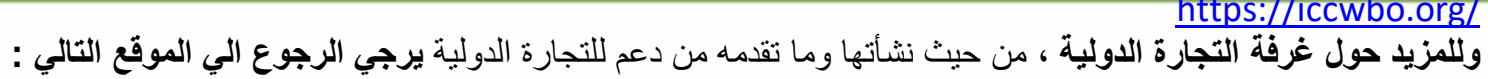
http://tfig.itcilo.org/AR/contents/org-icc.htm

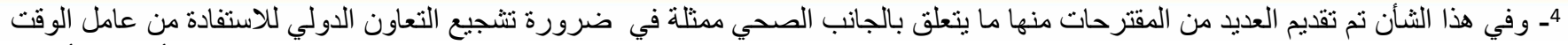

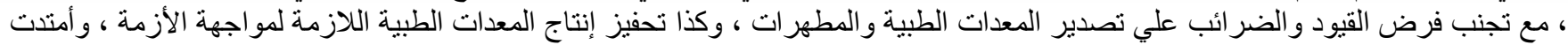

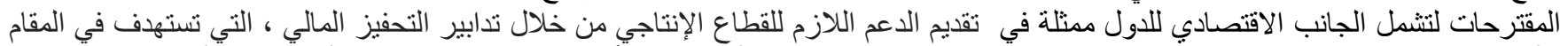

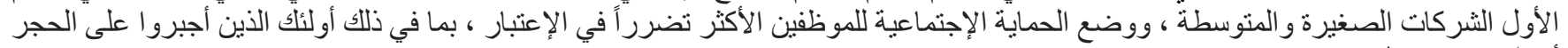

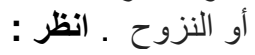
Appel ICC, OMS, B20 au G20 pour une approche coordonnee de la crise sanitaire et economique de la pandemie., 25/03/2020,

http://www.icc-france.fr/chambre-de-commerce-internationale-actualite-7-601-Actualites.html 
قرى معزولة عن بعضها في محاولة منها في منع تقشي واحتواء هذا المرض ، إذ لجأت الدول إلي اتخاذ إجراءات

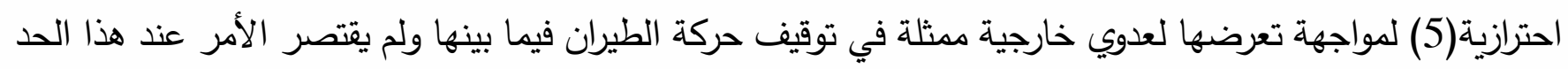
بل اتخذت بعض الدول - علي الصعيد الداخلي - إجراءات احترازية أكثر صرامة إذ فرضت حظراً للتجول الجزئي تارة والكلي تارة أخرى علي رعاياها وهو ما لجأت إليه كلا من إيطاليا و إسبانيا ولم تكتفي عند هذا الحد بل تم وقف حركة الانتقال بين محافظاتها وولاياتها المختلفة.

ولعل ذلك كان له بالغ الخطورة علي الاقتصاد العالمي إذ نتج عن ذلك إغلاق العديد من الأسواق العالمية نتيجة لتوقف العديد من الدول عن مواصلة نشاطها نتيجة لإجراء الحجر الصحي وتسريح العمال(6)، بالإضافة إلى صعوبات شديدة في الاستيراد والتصدير (7)نتيجة توقف العديد من المدن الصناعية وانخفاض أسعار العديد من مواد الخام الأولية والمثال الأبرز علي ذلك مدينة ووهان الصينية - بؤرة انتثار الفيرس في الصين و العالم - المتربعة علي عرش تكنولوجيا المعلومات وهو ما أثر سلبا علي صادراتها،ولم يقتصر الأمر عند هذا الحد بل امتد أثره إلي العديد من الدول العربية مثل المملكة العربية السعودية و ليبيا واليمن.

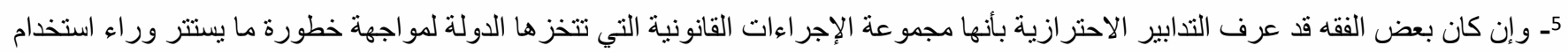

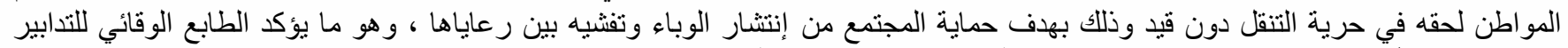

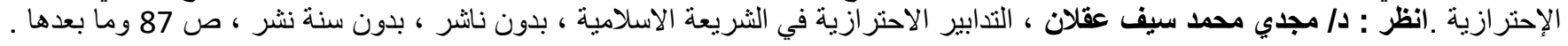
file:///C:/Users/DELL/Downloads/46-181-1-PB.pdf

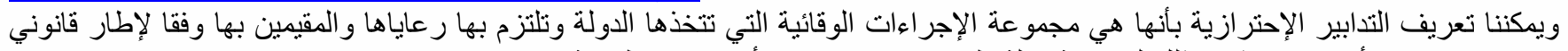

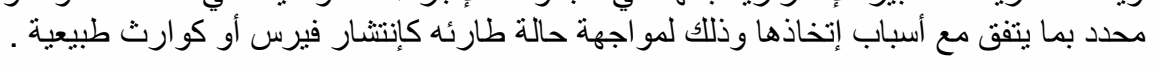

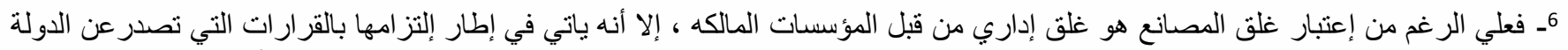

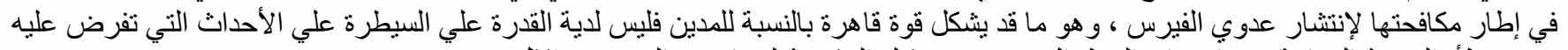

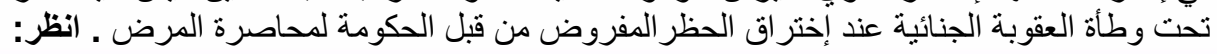

Gastebled (É), Le clair-obscur de la force majeure en matière contractuelle face au Covid-19, ublié le10/04/2020 mis à jour le 10/04/2020 à $18 \mathrm{H} 55$

https://www.actu-juridique.fr/civil/obligations-contrats/le-clair-obscur-de-la-force-majeure-en-matierecontractuelle-face-au-covid-19/

: - - انظر

Canet (L) ,Coronavirus : comment répondre à la force majeure invoquée par la Chine dans ses relations commerciales, jeudi 27 février 2020 .

https://www.village-justice.com/articles/coronavirus-comment-repondre-force-majeure-invoquee-parchine-dans-ses,33920.html 
ولم تكن مصر منه ببعيد بل حاولت مصر أن تجعل من المحنة منحة إذ وضعت الحكومة المصرية الفيرس موضع الدراسة من كافة جوانبه لتصل إلي حلول ناجعة لتخرج مصر من هذه الأزمة بأقل خسائر ممكنة ، ولعل ذلك مرجعه هو إدراك الحكومة المصرية لحجم الكارثة وتأثيرها السلبي علي الاقتصاديات الناشئة والمتقدمة علي السواء ، إذ تدخلت الدولة المصرية في محاولة منها للتخفيف من الآثار السلبية الناجمة عن اتخاذ التدابير الاحترازية أو الاعتماد علي احتياطها من النقد الاجنبي دون أن يؤثر بشكل مباشر علي الصناعة المصرية إذ منحت المصانع استثاءً من تطبيق قرارات حظر التجول - الذي تم إعلانه بموجب قرار مجلس الوزراء رقم 719 لسنة 2020 وما لحقه من القرارات المنفذه

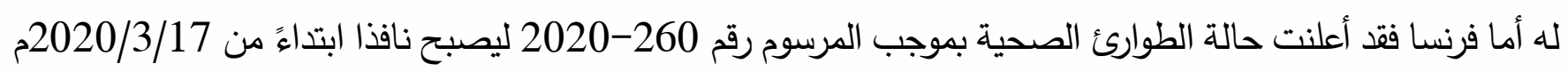
وما لحق به من قوانين وقرارات تتفيذا لما ورد به - بما يمكنها من الانتقال بحرية لنقل المستلزمات الإنتاجية في محاولات منها لتقديم الدعم الكافي للصناعة الوطنية ، وهو ما يبشر بأن هذه الازمة لن يكون لها تأثير سلبي علي الاقتصاد المصري ليصعد بمعدلات قد تتجاوز المؤشرات العالمية المتوقعه له، وهو ما ترجم علي أرض الواقع إذ هاذ صعدت مؤشرات البورصة المصرية و صاحب ذلك زيادة ملحوظة في حجم تعاملاتها علي الرغم من تهاوي العديد من بورصات الدول الصناعية الكبري و المتقدمة .

تجدر الإثارة إلي أن معظم الدراسات الاقتصادية تؤكد علي أن العالم واقتصادياته لن يعود مثلما كان قبل انتشار الفيرس الذي يثبه في تاثيره التسونامي ، إذ ستشهد الخريطة الاقتصادية للعالم تغير جوهري وملحوظ، لن يدرك العالم حجم هذا التغيير وتأثيره إلا بعد انتهاء الأزمة و الحرب ضد الفيرس سوالذي قد يستمر لأعوام قادمة خاصة مع توقع الخبراء تعرض العالم لموجات لاحقة أعنف من الفيرس قد تزيد في قوتها الموجة الحالية 2019-وإن كنا لا ننكر أن التاثير السلبي لهذه الحرب قد لاح في الأفق علي الرغم من أن الحرب لم تضع أوزارها بعد إذ لم تعُد الدول الصناعية

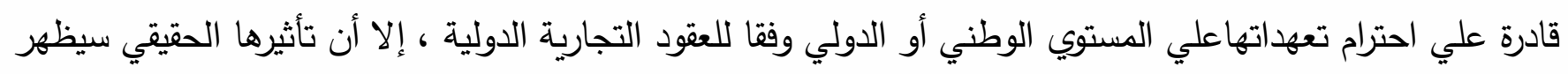
جليا حينما تعاود الدول الاقتصادية الكبرى أدراجها الي الاسواق لتجدها خاوية علي عروشها وتجد نفسها في صدمة يصعب علي اقتصادها الوطني تحملهإذ أصبح منهك لا يمكنه أن يتعافي سريعا خلال فترة قصيرة،لتصعد اقتصاديات بعض الدول الصناعية الناشئة أو النامية التي اعتمدت خلال هذه الأزمة علي انعاش وتتمية صناعته الوطنية لسد احتياجاتها بفعل التدابير الاحترازية التي فُرضت خاصة مع تقطع أوصال الدول وهو ما يمثل عائقا امام انتقال البضائع 
بين الدول لسد احتياجاتها الأساسية (8) ،لتتهض علي إثر ذلك صناعة وطنية قوية قادرة علي سد احتياجاتها والاستغناء عن الاستيراد كوسيلة لذلك لتبدأمن ثم مرحلة جديدة دن المنافسة علي الصعيد الدولي(9)، لتشهد الأسواق العالمية سطوع نجوم اقتصادية جديدة و أفول نجوم أخري تربعت علي عرش الاقتصادالعالمي لعقود مضت. وإذا كان من شأن انتشار هذا الفيرس كل هذا التأثير علي الاقتصاديات الكبري ، فمن المؤكد أنها ستوثربشكل مباشر وقوي علي قدرة طرفي العقود في عقود التجارة الدولية ( المبحث التمهيدي) - التي تم توقيعها في الفترة السابقة علي ظهور الوباء أو انتشارها - علي مواجهتها لتواصل تنفيذ التزاماتهم التي تضمنتها بنوده دون تقصير أو إخلال وهو ما يضعنا أمام تساؤل مهم حول مصير تتفيذ هذه العقود في ظل هذه الأزمة التي عصفت باقتصاديات دول عظمي وهوما لا يقل تأثيرًا علي الثركات التجارية التي تعد طرفا في مثل هذا النوع من العقود كوسيلة لسد احتياجات الدولة باعتبارها أحد أهم سبل التبادل التجاري الدولي وهو ما يضع الدولة والثركات الوطنية و الأجنبية في مأزق تنفيذها وهل هي واجبة النفاذ حتي مع اعتبار ذلك دربا من دروب الخيال لخروجها عن إرادة أطرافه -معيار المظهر الخارجي -ودخولها في نطاق القوة القاهرة (10) بما يترتب عليها من انتفاء المسئولية عن عدم التنفيذ أو تعويض الطرف المتضرر لتقاعص

8ـ اذ أدي انتثار فيرس كورونا إلي إتخاذ مجموعة من الإجراعات بثكل مباثر وسريع ممثلة في : 1- إغلاق أماكن العمل ومحاور التسليم ،

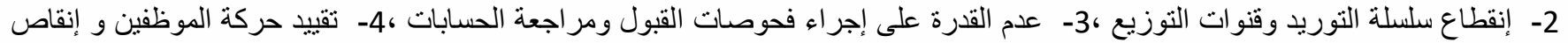
أعدادهم 5- إلغاء الأحداث أو تعليقها أو تأجيلها ، 5- خفض الطلب الفرة الإقليمي بشكل ملحوظ. انظر :

Herau-Yang $(\mathrm{H})$,Coronavirus et contrats: force majeure, or not force majeure?, 01/03/2020 .https://lepetitjournal.com/hong-kong/coronavirus-et-contrats-force-majeure-

9- غير أن عقود التجارة الدولية غير قاصرة علي ذللك وحسب ، بل تمند لتشمل عقود الإنتاج و التوريد ونقل التكنولوجيا وعقود إنثاء السكك الحديدية

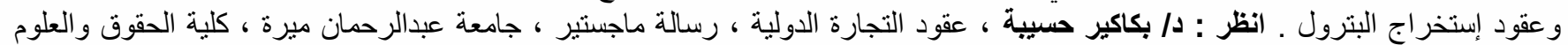

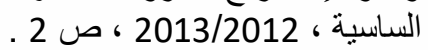

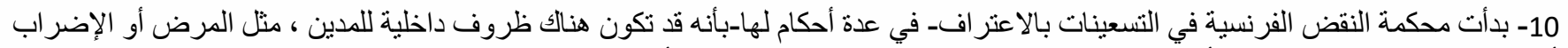

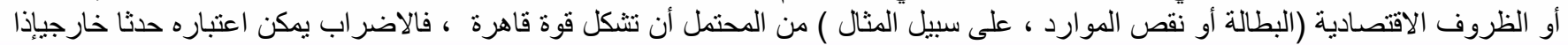

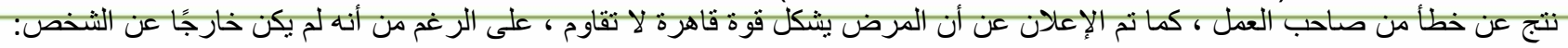

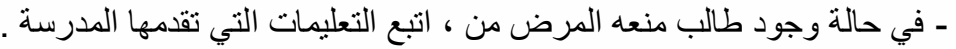

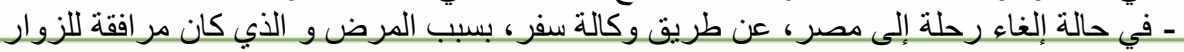

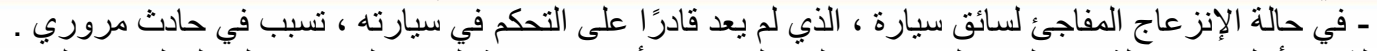

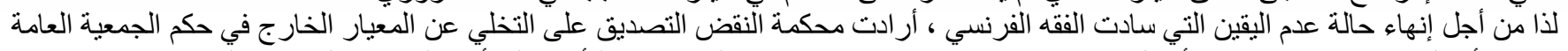

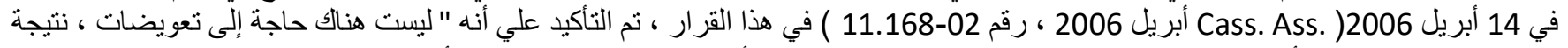

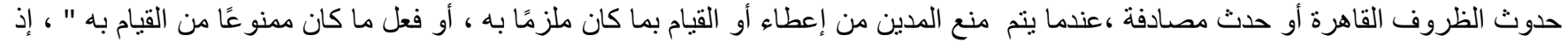

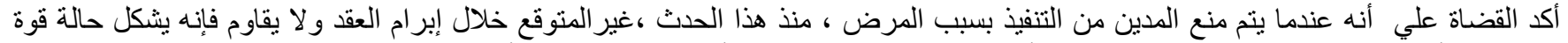

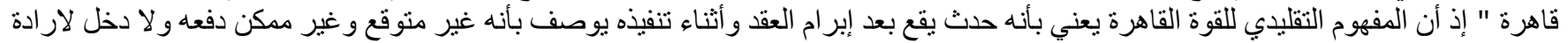

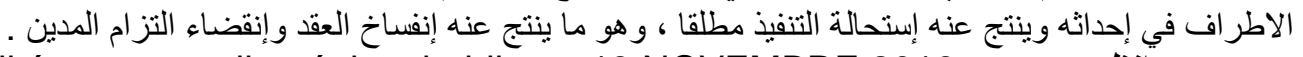
Bamdé (A),La responsabilité contractuelle: régime juridique, 19 NOVEMBRE 2019 , : https://aurelienbamde.com/tag/force-majeure/ 
الطرف الآخر عن تتفيذ بنود العقد ، إذ تشكل القوة القاهرة واحدة من العلاجات القوية لمساعدة المدين علي تبرأة نفسه من أي مسؤولية، وهو ما تعرض له القانونين المدني المصري و الفرنسي والمادة (79) من اتفاقية الأمم المتحدة بشأن عقود البيع الدولي للبضائع 1980 (11)، إذ وضعت جميعا شروطا محددة لإعفاء أحد طرفي عقود التجارية الدوليةهن المسئولية (المبحث الاول ) حال إخلاله بأحد الالتزامات المنبثقة عنه نتيجة تفشي فيرس كورونا و اعتباره وباءً عالميا بما له من تاثير علي العلاقة التعاقدية التي تلزم طرفي العقد وفقا لبنوده محاولة إعادة التوازن العقدي الذي تعرض للإخلال بسبب انتشاره وسلوك طريق الحلول الودية القائمة علي مبدأ حسن النية وذلك بإعادة التفاوض أو اللجوء إلي التحكيم (12) ، بما يمنح الطرفين الفرصة الكافية التي تمكنهم من مواصلة تتفيذ العقد دون إرهاق أو استحالة في التنفيذ والتي قد تودي بحياة العقد بما من شأنه أن يضع سطور النهاية في حياة العقد المبرم بينهم ( المبحث الثاني ) . هدف البحث :يهدف البحث في هذا الموضوع إلي مساعدة الشركات والأفراد أطراف العلاقة العقدية ذو الإطار الدولي علي مواجهة كافة الآثار السلبية الناجمة عن انتشار فيرس كورونا ، وذلك من خلال الإستعانة بالاتفاقيات والمبادئ الدولية المتعلقة بالتجارة الدولية والتي جعلت من القوة القاهرة سببا لانتفاء المسئولية عن إتمام الالتزامات التعاقدية تاسيسا علي أنه لا الالتزام بمستحيل ، وذلك في محاولة لوضع الإطار القانوني لتنفيذ عقود التجارة الدولية وقت الأزمات (13) والتي يستحيل معه التنفيذ وهو ما يشكل إرهاقا علي المتعاقدين خاصة إذا كانت الدولة محل تنفيذ العقد قد اتخذت من التدابير الاحترازية ما يحول دون ذلك ، لذا كان لزاما علينا أن نتعرض لحالة انتفاء المسئولية عن عدم تتفيذ عقود

11 - تجدر الإثـارة إلي أن الدول لجأت إلي الاتفاقيات الدولية المتعلقة بالجانب الاقتصادي والتجاري بغرض الوصول إلي حل لكافة المشكلات التي قد

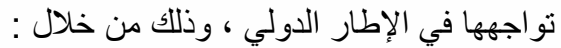

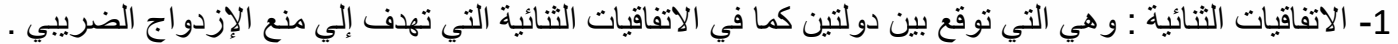

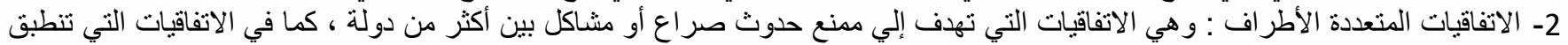

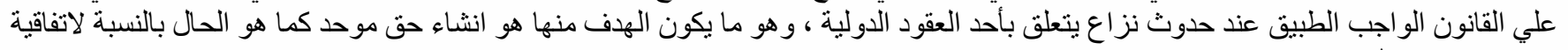
فيينا 1980 ـ انظر الفران

Centre du Commerce International , La dimension juridique du commerce international , Cultre de l'exportation ,2020, http://www.intracen.org/uploadedFiles/intracenorg/Content/Redesign/Projects/PACIR_UEMOA/ITC-module $\underline{6 . p d f}$

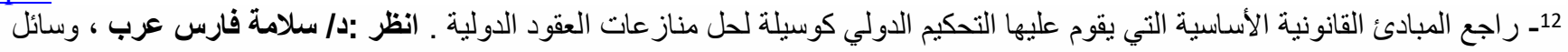

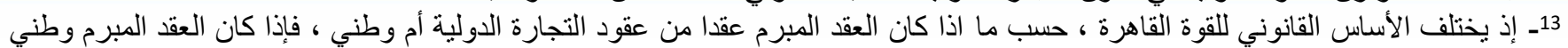

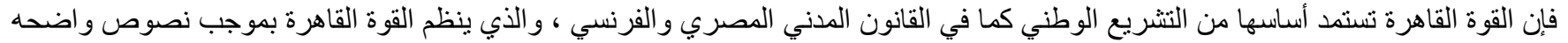

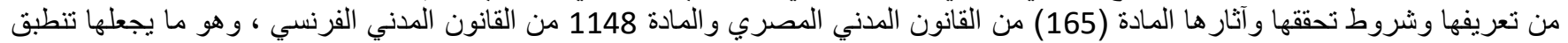

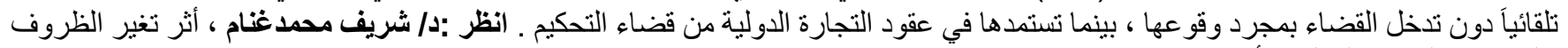

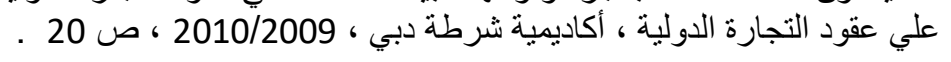




\section{منى عمار}

التجارة الدولية لانتشار فيرس كورونا باعتباره عائق - يؤدي الي قطع السببية بين خطأ المتعاقد والضرر الذي لحق به فانعدمت المسئولية وانتقت المسئولية (14)- وهو ما يعد طوق النجاة للعديد من المتعاقدين خاصة ذو الطابع الدولي ، إذ يحميهم من تحمل تبعات عدم التنفيذ والممثله في التعويض عن كافة الأضرار التي تنجم عن ذلك وهو ما قد يؤدي في كثيرا من الحالات إلي فقده لتجارته فكما لفيرس كورونا آثاره المدمرة علي الأرواح فإن له ذات الأثر علي الاقتصاديات والتجارة .

إثكالية البحث : لعل تعرض العالم إلي وباء فيرس كورونا وما حمله في طياته من خسائر في الأرواح والأموال قد أدي إلي إرباك العالم اقتصاديا وصحيا فلم يكن بوسع العالم أن يتوقع حدوثه بما يمنحهم فرصة اتخاذ كافة التدابير الاقتصادية والصحية اللازمة لتفادي الخسائر أو التقليل منها ، وهو ما انطبق علي عقود التجارة الدولية التي وجد اطرافها أنفسهم في معزل عن تنفيذه نتيجة اتخاذ كافة دول العالم لتدابير احترازية تحول دون الانتقال بينها أو بين مقاطعات الدولة الواحدة وهو ما أصبح معه تتفيذ عقود التجارة الدولية او الداخلية مرهقا جدا أو مستحيلاً- ويستوي أن تكون الاستحالة مادية أو معنوية - وهو ما يمنح الطرف الآخر الذي يصيبه الضرر عن عدم التنفيذ في الرجوع علي الطرف الأخر الملزم بالتتفيذ بالتعويض رغم عدم صدور أي تصرف يشير إلي حدوث خلل من قبل الطرف الملزم بالتنفيذ وأن الأمر خارج عن إرادته نتيجة انتشار فيرس كورونا وما لحق ذلك من تدابير - تعد عائق في التتفيذ- لذا حاولنا أن نقدم لطرفى العلاقة التعاقدية في عقود التجارة الدولية الذي أخل بالتزاماته التعاقدية نتيجة انتشار فيرس كورونا السبيل الذي يمكنه الارتكان إليه لدفع المسئولية الناجمة عن تقصيره في التنفيذ خلال انتشار فيرس كورونا باعتباره عائقً .

منهج البحث : عمدنا في هذه الدراسة إلي الاستعانة بكافة مناهج البحث العلمي سواء المنهج الوصفي أم التحليلي أم المقارن لدراسة تتفيذ عقود التجارة الدولية وقت انتشار فيرس كورونا باعتباره عائق يحول دون ذلك ، إذا استعنا بالمنهج الوصفي عند التعرض لنصوص الاتفاقيات والمبادئ الدولية المنظمة لعقود التجارة الدولية والمنهج التحليلي بهدف تفسير المبادئ والاتفاقيات الدولية والقوانين الوطنية بينما استعنا بالمنهج المقارن عند تعرضنا لمعالجة التشريعات الوطنية لبعض الدول والتي اعتبرت فيرس كورونا عائق يحول التتفيذ كالتشريع الفرنسي •

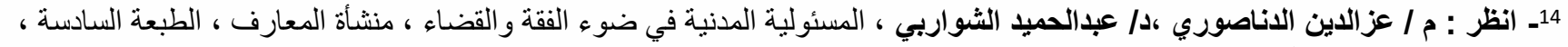

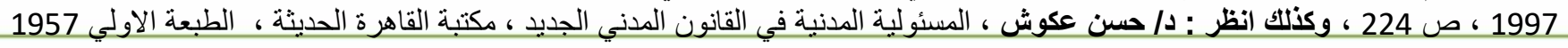


خطة البحث : نقسم هذه الدراسة الي مبحثين يسبقهما مبحث تمهيدي بحيث نعالج في المبحث التمهيدي ماهية العقود التجارة الدولية باعتباره الركيزة الأساسية للدراسة ومن ثم نتناول في المبحث الأول سبل الإعفاء من المسئولية الناجمة عن الإخلا بتنفيذ عقود التجارة الدولية لانتشار جائحة كورونا من خلال التعرض لشروط اعتبار الفيرس قوة قاهرة ينتفي معها المسئولية ثم تناولنا في المبحث الثاني أثر اعتبار فيرس كورونا عائق أمام تتفيذ عقود التجارة الدولية .لذا سنتاولها بالبحث من خلال المباحث التالية : المبحث التمهيدي : ماهية عقود التجارة الدولية . المبحث الاول :سبل الإعفاء من المسئولية الناجمة عن الإخلال بتتفيذ عقود التجارة الدولية لانتشار جائحة كورونا المطلب الاول :اعتبار فيرس كورونا عائق أمام تتفيذ عقود التجارة الدولية . المطلب الثاني : عدم إمكانية التنبؤ بتعرض العالم لفيرس كورونا وقت توقيع العقود . المبحث الثاني : أثر اعتبار فيرس كورونا عائق أمام تتفيذ عقود التجارة الدولية. المطلب الاول :إعادة التفاوض بشأن بنود العقود. المطلب الثاني :إنهاءعقود التجارة الدولية.

\section{المبحث التمهيدي}

\section{ماهية عقود التجارة الدولية}

لم تصل التجارة الدولية وعقودها إلي ما هو عليه الآن فجأةً إذ لم تكن وليدت اللحظه وإنما خضعت لتطور تاريخي كانت بدايتة في أوائل الثمانيات حينما تبنت الدول المتقدمة فكر اقتصادي جديد يحمل تسميةالعولمة بما تحويه من آفاق تجارية جديدة ، وهو ما جعل الحديث عنها يرتبط في الأزهان بالدول المتقدمة اقتصاديا، معتمدةً في ذلك علي تحرير الشركات الدولية من القانون الوطني وهو ما سمح لها بإنشاء مساحة مالية وتجارية خارج حدود الدولة بما منحها فرصة اختراق العديد من أسواق العالم رغم مواجهته بالرفض (15)الذي لم يدم طويلاً ، إذ توجت المساعي في النهاية

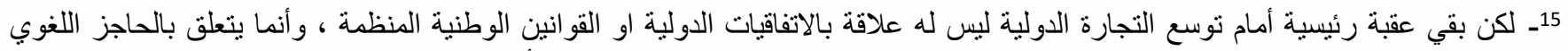

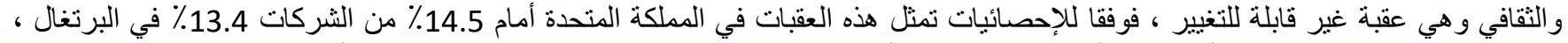

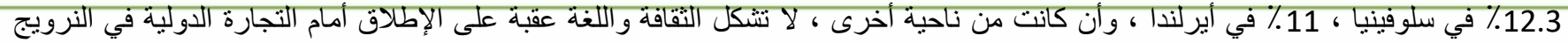


باستسلام تام من جانب دول المجتمع الدولي لنصبح بصدد مجتمع تجاري متجانس نسبيًا مع القاضي الوطني بفضل التحكيم التجاري الدولي (16).

ونظرا لصعود نجم عقود التجارية الدولية خلال الآونة الأخيرة كوسيلة للتبادل التجاري بين دول العالم بما يتمتع به من ميزة حرية أطرافه في تحديد القانون الواجب التطبيق (17) ، فقدتم أخضاعها للتطور والدراسة من جانب فقهاء القانون في محاولة منه لرسم الحدود والقواعد التي تتظمه بما يجعلها أكثر وضوحا وسهولة علي المتعاملين بها وهو ما يؤكد علي ذاتية قانون التجارة الدولية ، لذا تدخل الفقه لوضع تعريفا محددا لها خاصة مع إِعراض الاتفاقيات الدولية والقوانين الوطنية عن وضع تعريفا لها (أولاً)، ولعل ذلك يتقق مع طبيعتها الذاتية التي نتج عنها اختلاف في الالتزامات التي تفرزها هذه العقودحسب نوعها و بنودها ،وبالتالي فان بنود هذه العقود هي وحدها من تحدد الإطار العام للالتزامات التي يتم علي أساسها تحديد مدي التزام أطرافها من عدمه ،ليتم بموجبها الرجوع علي الطرف المقصر بالتعويض عن الأضرار التي لحقت به نتيجة اخلاله ببنود العقد أو بالرجوع إلي القواعد العامة للمسئولية والتي بموجبها يلتزم بتعويض الطرف المضرور عن الضرر الذي لحق به ما لم تتوافر المبررات التي تعفي من المسئولية (ثانياً) ، ولعل محاولات الفقهاء هذه ستصب في مصلحة الدول النامية -التي تلجأ إليها كوسيلة لسد احتياجاتها - من خلال مساعدتها علي فهم أعمق لهذه العقود ليتثكل لديها وعي قانوني بشأنها بما يساعدها علي تتشأت جيل جديد من الخبراء الوطنيين

Barbosa (A) , Les top 5 des obstacles au commerce international , $6^{\text {th }}$ aout 2019 .https://www.intercountry.com/blog/les-top-5-des-obstacles-au-commerce-international/

Godel (M) , Les contrats du commerce international , Cours du Professeur Jacquet, Institut de Hautes Etudes Internationales, Genève ,2019.

http://hei.stoessel.ch/dip/contrats_commerce_international_jacquet.pdf

17- إذ نعتمد عملية تحديد القانون الواجب التطبيق علي قدرة الطرفين عند التفاوض ، فعملية اختيار القانون الواجب التطبيق يعد من أكبر المشكلات

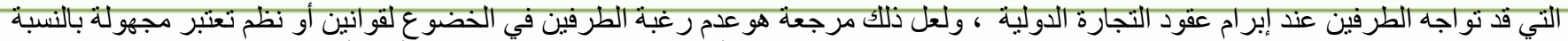

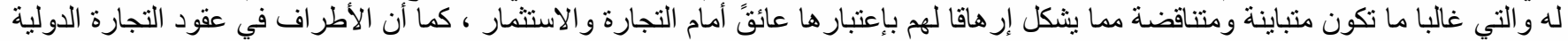

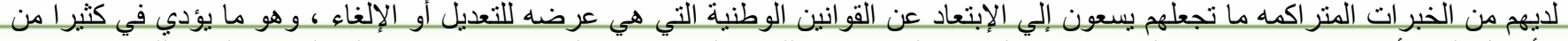

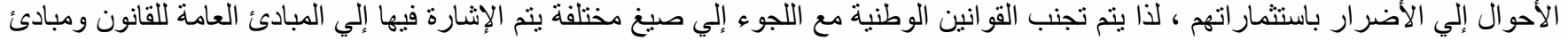

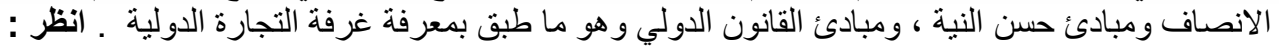

Gagné (L) , Les contrats commerciaux internationaux et les systèmes de droit civil et de common law, Revue générale de droit, Document généré le 11 avr. 2020 02:48 , P.49-50 .

https://www.erudit.org/fr/revues/rgd/2002-v32-n1-rgd01658/1028054ar.pdf 
القادرين علي التفاوض وإبرام عقود دولية أكثر توازنا دون إجحاف عليها لذا يكون من المهم التعرض لهذه العقود باستفاضه.

\section{أولاً : تعريف عقود التجارة الدولية :}

علي الرغم من تدخل العديد من الاتفاقيات الدولية لمعالجة هذا النوع من العقود ، إلا أنها لم تقحم نفسها في وضع تعريفا لها ، خشية أن تضعها في قالب جامد وهو ما يتنافي مع طبيعة الحياة التجارية -التي تتميز بسرعة وتيرتها وتطورها - وطبيعة القاعدة التشريعية - بما تحمله من عمومية صفتها - التي تقف عاجزة أمام معالجة كافة الحالات لذا يتسم هذا النوع من العقود بالمرونة الكافية التي تسمح بمعالجة كافة المشكلات التي يفرزها الواقع العملي ، إذ تسمح هذه العقود لطرفيها أن يُصيغها وفقا لما يواجههم و ما يحقق مصالحهم لنصبح بصدد عقد متوازن دون إجحاف علي أحد طرفيه فلا مجال هنا لأن يتمكك ايا من طرفيه بنظام قانوني معين سواء كان وطنيًا أو دوليًا ، وهو ما أدركه الفقه فلم يسعي إلي التتخل بأن يلزم الأطراف باتباع نهج معين أو تعريف محدد له . وعلي الرغم مما سبق إلا أنه يمكننا أن نعتمد علي فكرة متوازنة بتوافر معياري دولية العقد وتجاريتة بحيث يتم دمج المعيارين ليكون سندا لإسباغ صفة الدولية علي العقود التجارية بأن يتم إبرام عقد تجاري(18) وفقا لما يشترطه القانون الوطني في العقد - تجاريته - لكن يتم ذلك في الاطار الدولي بغض النظر عن جنسية أطرافه مع الاعتماد علي مكان تنفيذ العقد أو مركز أعمال الطرفين دون ترجيح معيار علي حساب الآخر وفقاً لما تبني الفقه الذي اكتفي دوره علي وضع معايير معينة يجب توافرها لنكون بصدد عقد تجاري دولي ، ممثله في :

1- دولية العقد : لا يعتمد هذا المعيار علي ما يحمله أحد أطرافه من جنسية، وإنما يخضع توافر هذه الصفة في

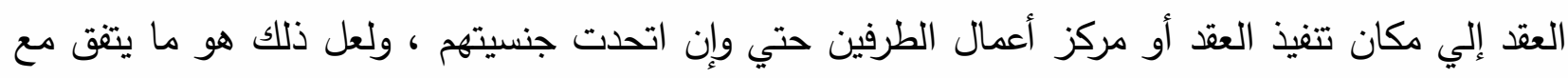
طبيعة الععل التجاري الذي ينظر إلي النشاط التجاري ذاته كوحدة مستقلة عن شخص التاجر ، وبالتالي يكون من المنطقي ان ينظر الي العمل وفقا لمركزه وليس إلي جنسية أطرافه ولا الصفة التجارية أو المدنية للأطراف (19)، فلا مجال للبحث عن توافر الصفة سواء كانت مدنية أو تجارية في طرفي العقد التجارى الدولي، ولعل

18- إذ تتميز عقود التجارة الدولية بأنها عقود رضائية و عقود معاوضة ونرد علي منقو لات وعقار ، وات .انظر : د/ حنان عبدالعزيز مخلوف ، العقد

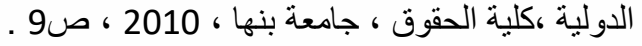

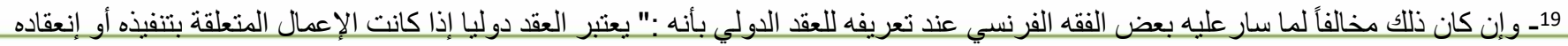

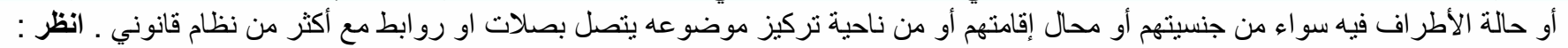
Batiffol (H) ,Repertique de droit international contrats et conventions, Encycloprdie juridique ,Dalloz,p.564 . 
ذلك هو ما تبنته المادة (1) من اتفاقية فيينا 1980 بشأن عقود البيع الدولية للبضائع حينما نصت علي : "

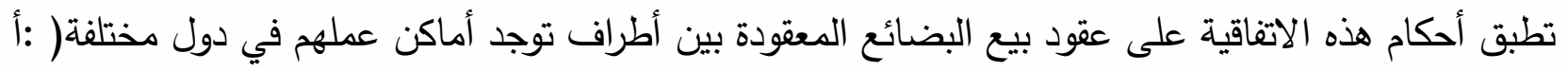
(عندما تكون هذه الدول دولا متعاقدة ;أو (ب (عندما تؤدي قواعد القانون الدولي الخاص إلى تطبيق قانون دولة متعاقدة (2) ـلا يلتقت إلى كون أماكن عمل الأطراف توجد في دول مختلفة إذا لم يتبين ذلك من العقد أو من أي معاملات سابقة بين الأطراف، أو من المعلومات التي أدلى بها الأطراف قبل انعقاد أو في وقت انعقاده . (3(لا تؤخذ في الاعتبار جنسية الأطراف ولا الصفة المدنية أو التجارية للأطراف أو للعقد في تحديد تطبيق هذه الاتفاقية."،وان كان البعض (20) يري أن توافر عنصر أجنبي أو عناصر معينةفي نطاق الاتصال بين دولتين علي الأقل هي نقاط كافية لجعل العقد دولي وإن كان يتقق مع هذا المعيار جانب اخر من الفقة الفرنسي

يسري علي عقود التجارية الدولية ما يسري علي العقود التجارية بوجة عام في النطاق الوطني غير أن العقود الدولية تعد حلقة الوصل بين قواعد القانون الدولي العام والخاص ، فالعقود المدنية تصلح لأن تكون عقودا تجارية إذا اندرجت في عداد الأعمال التجارية (22)، وبالتالي فإن معظم العقود التي يوقعها التاجر كعميل هي عقود تجارية كما في الإيجار، وشراء المواد الخام أو المعدات ، والأعمال ، إلخ ، وهنا يكون من المهم فهم ما ينطوي عليه هذا النوع من العقود مقارنة بالعقود المدنية ، ولعل ذلك هو ما يفسر عدم إمكانية حصر العقود التجارية أو وضع تعريفا محددا لها

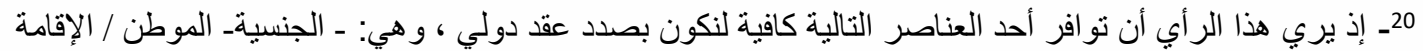

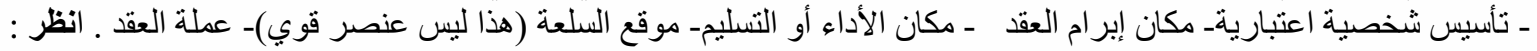

Godel (M) ,Les contrats du commerce international , Cours du Professeur Jacquet, op.cit.p.3.

21ـــ إذ اعتبر العقد دوليا حال إرتباطه بنقاط تلاق مع أكثر من نظام قانوني بما لا يجعل عناصره تنركز في نظام قانوني واحد ـ انظر : LOUSSOUARN (Y) \&BREDIE (J.D), Droit du commerce international , paris 1969, p.593.

22- يعتبر العقد تجاريًا عندما يتم وضعه لتسوية فعل تجاري أو عند ما يستعين به التاجر لتلبيه احتياجات نشاطه التجاري ، و وعلى سبيل المثال تعدمن

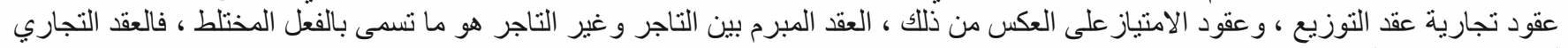
لا له خصوصبية ممثلكة في أن النشاط محل العقد تخضع للقانون التجاري ، ولعل مايميز العقود التجارية عن غير ها من العقود الأخرى هي:

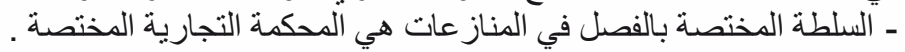

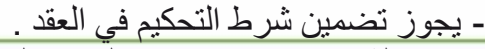

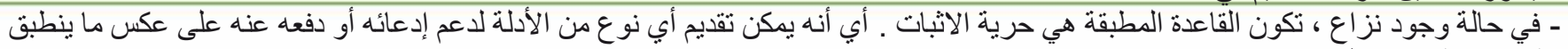

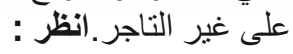
DESERT (A) , Qu'est-ce qu'un contrat commercial ?, Focus sur les particularités légale du contrat commercial , Publié le 26/06/2019, https://www.toute-la-franchise.com/vie-de-la-franchise-A31940-qu-est-ce-qu-uncontrat-commercial.html 
و إنما يتم تطبيق المعايير التي وضعها المشرع المصري في المواد 4،6، من قانون رقم 17 لسنة 1999 والذي اخذ بالمذهب المادي لاعتبار عمل ما تجاريا من عدمه والتي قسمها إلي أعمال تجارية وفقًا لطبيعتها الذاتية أو لاعتبارها أعمال تجارية بالتبعية ، وما ارتبط به من توافر شرط التاجر في من يمارس هذا العمل بغض النظر عن طبيعة العقد المبرم ، فقد يكون العقد مدنيا بالنسبة لأحد أطرافه وتجاريا للطرف الآخر •

تجدر الاشارة إلي ان أختلاف الغاية التي يسعي إلي تحقيقها طرفي العقود التجارية سواء داخليا - علي المستوي الوطني - أو خارجيا - في نطاق دول عديدة - لا تختلف من حيث نتائجها فكلا منهاعقودا تجارية تتميز بكونها تقوم في الأساس علي المضاربة كما أنها عقود رضائية وعقود معاوضة وهي صفة مطلقة في العقود التجارية(23) إلا أنه يبقي اختلاف جوهريً بين قواعد القانون التجاري الوطني المطبق علي المعاملات التي تتم في إطار الدولة وبين قواعد القانونية المطبقة علي عقود التجارة الدولية ممثلاً في أن طرفي العقد في النطاق الوطني تبقي ملتزمه بالنصوص التشريعية الوطنية الحاكمة لعلاقتهما بينما في نطاق العقود التجارية فإنها تتجاوز حدود الدولة لتطبق علي العلاقات التي تتشأ في نطاق اكثر من دولة كما أنها تخضع لسلطان الارادة (24) وبالتالي يتم تغليب اتفاق الطرفين علي كافة النصوص التشريعية الحاكمة في القوانين الوطنية لكلا الطرفين(25)، ولعل ذلك مرجعه هو افتقار التشريعات الوطنية إلي صفة الدولية وهو ما يعد دليلا علي عدم قدرتها علي مواكبة التجارة الدولية بما تتمتع به من خصوصية وما تتسم به من ذاتية (26) بما يسمح برفع الحواجز الاقتصادية والتجارية بين الدول مما ينتج عنه تقليل التكلفة وسرعة حركة التجارة بينها للتقليل من الحواجز الجمركية (27).

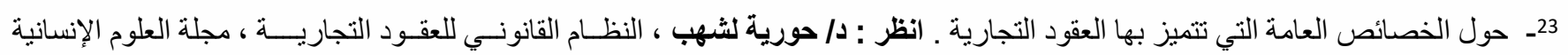

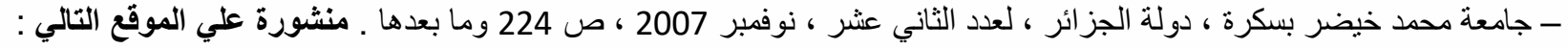
http://www.webreview.dz/IMG/pdf/ 1-2.pdf

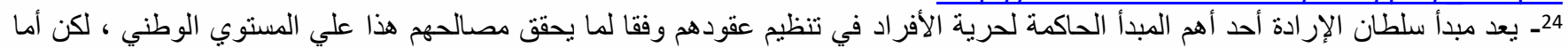

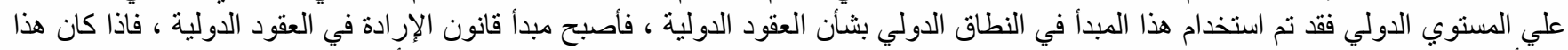

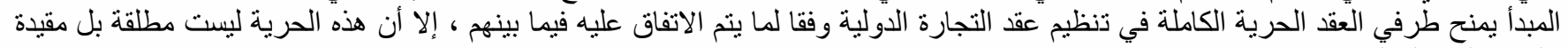

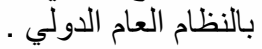
25ـ انظر : دام لحمود سمير الثرقاوى ، العقود التجارية الدولية دارسة خاصة لعقد البيع الدولى للبضائع ، دار النهضة العربية ـ القاهرة ، 1992

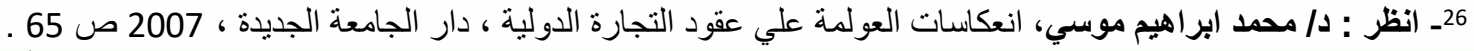

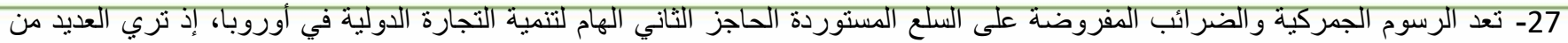

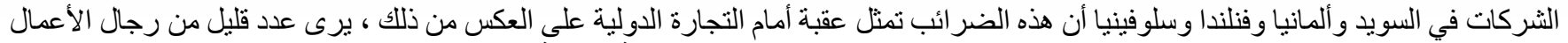

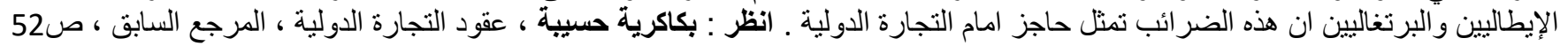

Barbosa (A), Les top 5 des obstacles au commerce international ,op.cit . 
ولعل هذه المعايير هي ما اعتمد الفقه عليها عند وضع تعريفا محددا للقانون التجاري الدولي (28 ) وإن اختلفوا فيما بينهم حول تبني معيار دون آخر أو هما معا ، وهو ما يتضح من تعريف البعض(29) له أنه " مجموعة القواعد التي تعالج علاقات التجارة الدولية والمستمدة من التشريع الدولي كالاتفاقيات الدولية(30) التي تبنت تشريعات موحدة وتلك المستمدة من العقود النموذجية ( ${ }^{31}$ والشروط العامة التي تضعها وتروج لها المنظمات الدولية التجارية الخاصة مثل غرفة التجارة الدولية أو العامة مثل اللجنة الاقتصادية لأوروبا في الأمم المتحدة فضلا عن العادات التجارية الدولية التي تنشأ عن النشاط العفوي والتلقائي للتجار والشركات غير الوطنية .

كما عرفه البعض بوضع تعريفا مقيدا له: "القانون التجاري الدولي معني بدراسة القواعد المطلوبة لتظيم العلاقات الاقتصادية الدولية التي يتم تشكيلها بين المشغلين من الأفراد ، أو بين الشركات"، وبالتالي فإن القانون التجاري هو

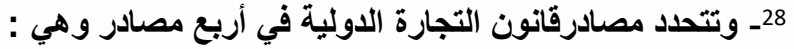

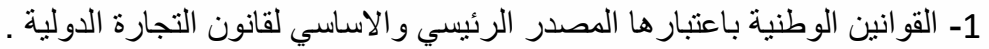

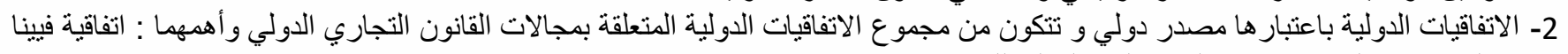

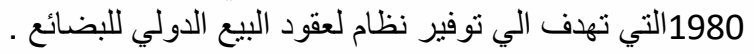

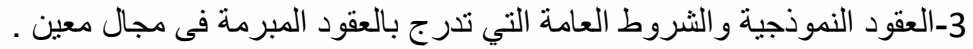

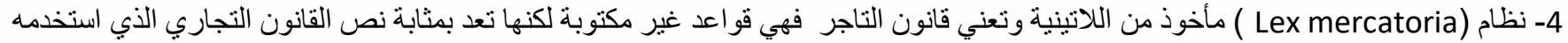

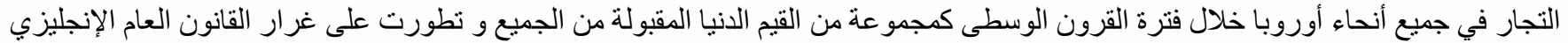

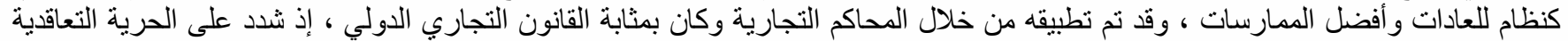

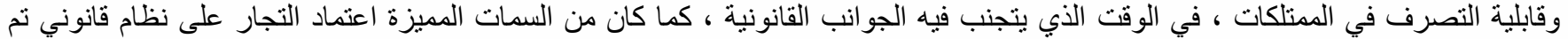

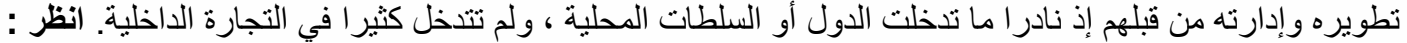
Wikipédia, Droit commercial international ,21décembre2018, https://fr.wikipedia.org/wiki/Droit commercial international

C.M. Schimithoff "International Business law, A new Law Merchant" Current law \& Social problems,P.129 www.ir,lawnet.fordham.edu/cgi/viewcontent.cgi

30- إذ وضعت الأمانة العامة للجمعية العامة لهيئة الأمم المتحدة عند البحث فى إنشاء لجنة لتوحيد أحكام قانون التجارة الدولية سنة 1965 تعريفًا

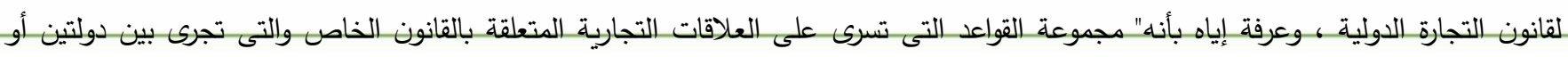

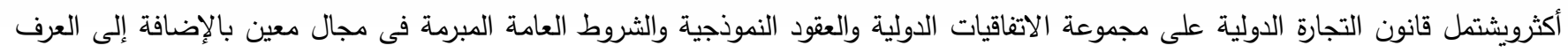

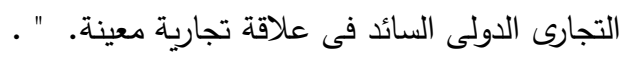

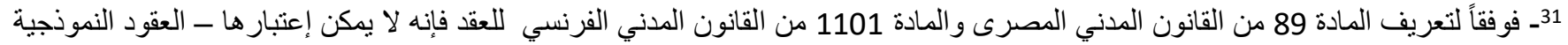

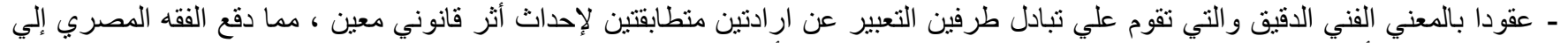

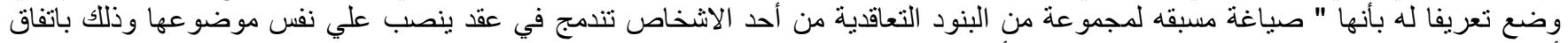

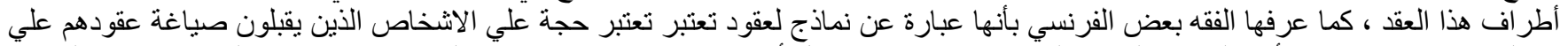

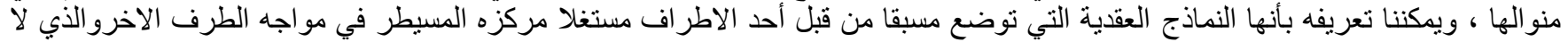

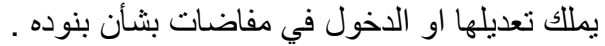

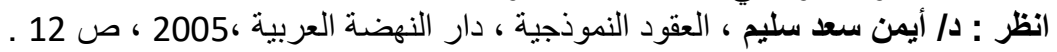
وكنلك انظر :

GHESTIN (J) , Traire de droit civil , la formation du contrat , 3 edition , L.G.D.J 1993 , no.80, p 60 . 
فرع من القانون يهدف أولاً إلى توفير قواعد قانونية تتطبق على العلاقات التي تنشأ بين الاقتصاديين ، عندما تكون حركةالمنتجات أو الخدمات ذات الصلة باقتصاد عدة دول.

ويمكننا تعريف عقود التجارة الدولية من خلال الاعتماد علي تعريف العقد التجاري كما هو محدد وفقا للقانون الوطني إلا أنه يتم في إطار دولي ولا يشترط لدولية هذا العقد أن يتم بين دولة ودولة أخرى فقد يتم بين شركتين وطنيتين لكن يتم تتفيذ العقد في دولة أخرى (32) وبالتالي يمكننا أن نضع معيار استرشادي لدولية العقد قد يأخذ أحد الصور بأن يتم إبرام العقد بين شخصين يحملان جنسيتين مختلفتين أو بين شخصين يحملان جنسية واحدة ولكن يتم تتفيذه في

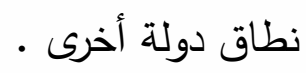

ثانياً -المسئولية الناجمة عن ابرام عقود التجارة الدولية :

ينتج عن ابرام عقود التجارة الدولية مجموعة من الالتزامات يتم تحديدها وفقا لبنود العقد وما يتحمله أطرافها من التزامات وما يتمتع به من حقوق مثله في ذلك مثل كافة العقود ، وبالتالي فإن إخلا أحد طرفيه بأداء ما عليه من التزامات ينتج عنه مجموعة من الجزاءات يحددها العقد المبرم أو القانون الواجب التطبيق من بينها منح الطرف الاخر الحق في التوقف عن أداء كافة التزاماته أو جزء منها ، وذلك تأسيسا علي اعتبار أن هذه الالتزامات هي التزامات تبادلية تستمد قوتها من العقد المبرم بين طرفيه وفقا لبنوده التي يجب أن تتسم بالتوازن (التوازن العقدي) دون إجحاف علي أحد طرفيه

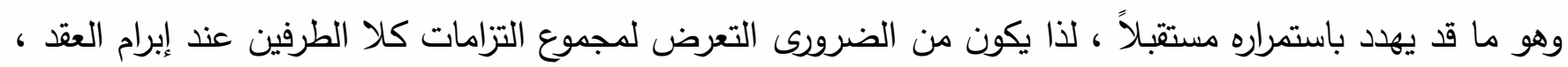

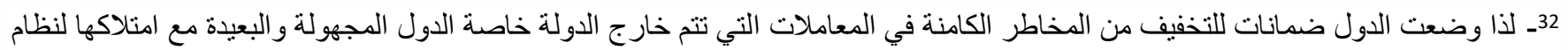

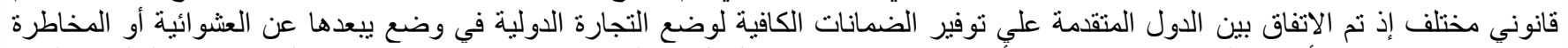

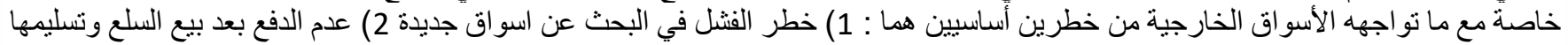

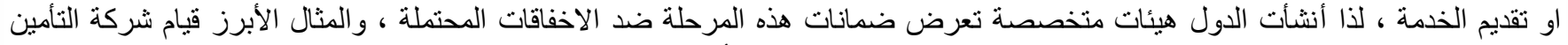

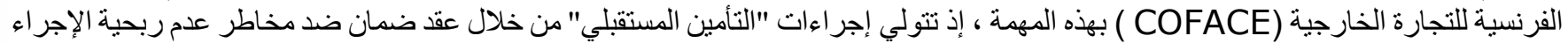

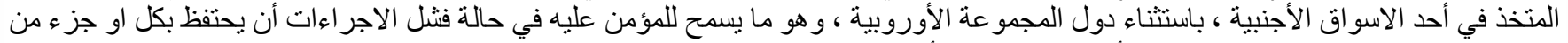

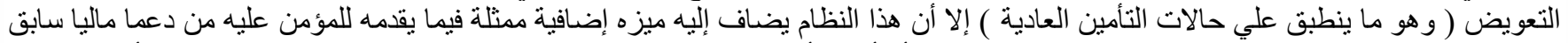

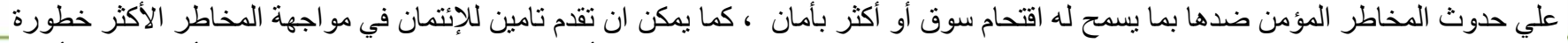

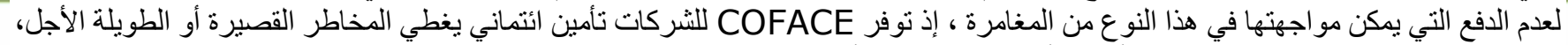

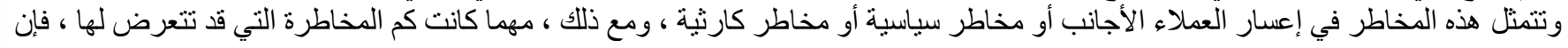

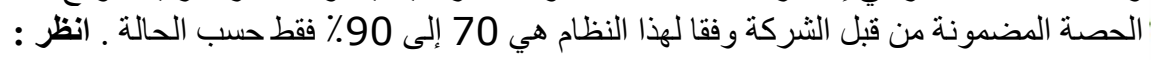

FONTANEAU (C) , La formation des contrats internationaux , Article publié dans la Revue «Fiscalité Européenne et Droit International des Affaires $\gg N^{\circ} 125$ (Année 2001) ,http://www.fontaneau.com/?p=350 
سواء كنا بصدد سلعه أم خدمة ، إذ تختلف الحقوق والالتزامات الناجمة عن العقد حسب نوع العقد المبرم والتي يتم استخلاصها من نص العقد ذاته ، إذ نادرًا ما يتم الاثارة إليها في مقدمة العقد كما يمكن الاعتماد علي المراسلات والمكاتبات التي تتم بين الطرفين في مرحلة التفاوض لتأكيد مثل هذه الحقوق وتلك الالتزامات شريطة أن يتم الإشارة إليها في العقد المبرم بين الطرفين وفي هذه الحال يسري علي تلك المراسلات ما يسري علي بنود عقود التجارة الدولية

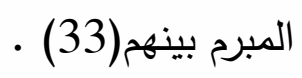

ونظرا لتعدد أنواع العقود التجارية والمجالات التي يمكن أن تصبح محلا لأحد عقود التجارة الدولية ، لذا يكون من الصعب الوقوف علي هذه الحقوق وتلك الالتزامات التي يتم تحديدها وفقا لبنود معينة يجب الاتفاق عليها، إذ تعد صياغة عقود التجارة الدولية جزءًا لا يتجزأ من الاستراتيجية التجارية للشركة لأنه وفقا للبنود التي يتم إدراجها ستتحدد مسئولية الطرفين، لذا هناك بنود معينة يجب علي طرفي العقدالانتباه اليها جيدا عند إبرامه ، والتي لا تتعلق بالثق القانوني والمالي للطرف الاخرفحسب-من خلالها يمكن الوقوف قياس مدي قدرته علي الوفاء بالتزاماته التعاقدية من عدمه- بل لها أبعاد شخصية ذات تأثير قانوني من اهمها(34) :

- معرفة المزيد عن الطرف الآخر في التعاقد باعتباره الثريك المستقبلي: من المستحسن جمع أكبر قدر ممكن من المعلومات حول وضع الطرف الآخر بعقود التجارة الدولية (السمعة ، الوضع المالي ، الإجراءات الجماعية ، إلخ) من أجل الحد من المخاطر .، وفي سبيل ذلك يمكن الاستعانة بمجموعة من المختصين والمشتغلين في

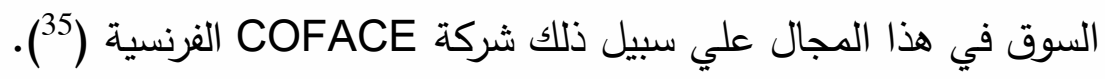
- كتابة العقد (الثكلية) : يجب تقديم العقد في شكل مكتوب فلا يمكن الاعتماد علي الاتفاقات الثفهية التي تتم

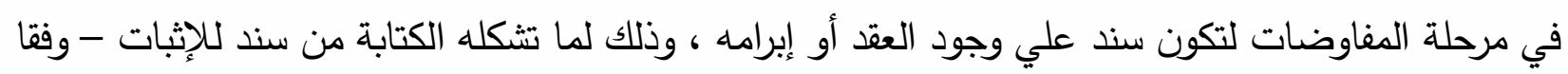

33ـ انظر:د/ عبدالواحد محمد ، د/ قادة بن شيحة محمد ، مر احل ابر ام عقود التجارة الدولية ، رسالة ماجستير ،معهد العلوم القتصادية و التجارية و

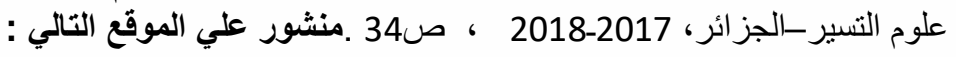
http://pmb-int.cuniv-aintemouchent.dz/memoire/\%D9\%80document.pdf : انظر

Llamazares (0) , Le Contrat International : 10 Questions Clés, Global Negotiator Blog , le 9 février, 2018, https://www.globalnegotiator.com/blog fr/contrat-international-definition/

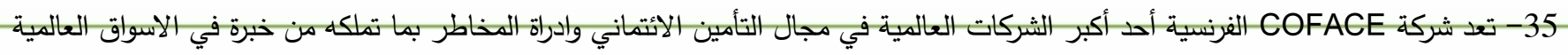
لاكثر من 70 عاما وما تملكه من فريق خبراء يقدمون الخدمة لحوالي 50000 شركة حول العالم ، إذ تقدم الثركة الدعم لعملائها في كل مكان يعملون

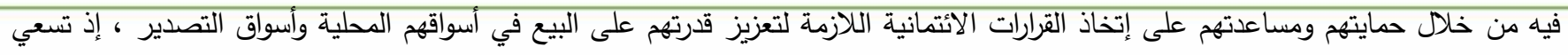

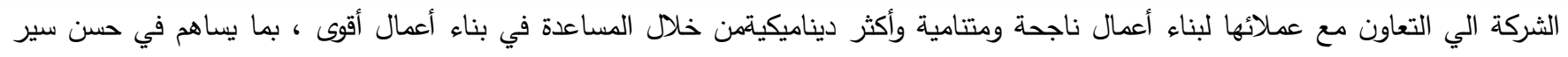

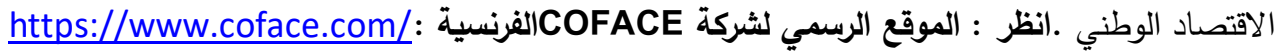


لمثل قانوني قديم " الكلام يهرب وتبقي الكتابة " وإن كان يمكن الاستتاد إلي البريد الالكتروني في ظل شروط

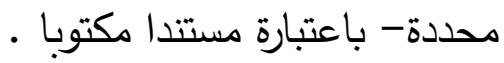

- - تحديد القانون الواجب التطبيق : يمكن للطرفين تحديد أي قانون يرغبون في الرجوع إليه عند ما ينشأ أي نزاع

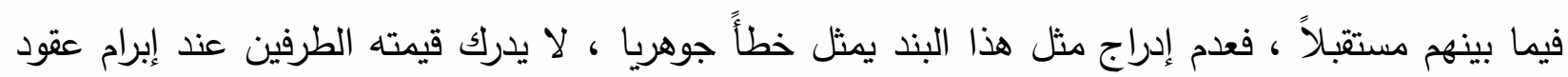
التجارة الدولية ، ولعل ذلك مرجعه هو عدم رغبة الطرفين في الخضوع لقانون ليس لديهم درايه كافية عنه ، لكن أهميته تظهر جليا لهما حال نشوب خلاف في التفيذ ، لذا يعد اختيار القانون الواجب التطبيق أحد أهم الأمور الاستراتيجية عند إبرام العقد ، خاصة إذا اتفق الطرفين علي اعتبار عدد من القوانين واجبة التطبيق علي النزاع كما لو اتفقا علي تطبيق قوانين مختلفة علي أجزاء مختلفة في العقد . - الاختصاص القضائي : والذي من خلاله يمكن تحديد الولاية القضائية أو هيئة تحكيمية حال حدوث النزاع ، فالنص في العقد علي المحكمة المختصة يساعد الطرفين علي تجنب إضاعة الوقت في تحديد المحكمة المختصة ، والتي قد تختلف من دولة اللي أخري حسب الولاية القضائية للمحاكم على سبيل المثال: في فرنسا يتم التعامل مع النزاعات المتعلقة بالوكلاء التجاريين من قبل محاكم الارجة الأولى وليس من قبل المحاكم التجارية بينما في مصر تختص بها المحكمة الاقتصادية . - - القوة القاهرة : إذا كان أحد نتائح وقوع القوة القاهرة هو انتفاء المسئولية عن عدم التنفيذ فإنه يجب علي الطرفين أن يخضعا هذا البند للوضوح التام من خلال سرد الحالات التي تشكل قوة قاهرة بحيث تكون من الوضوح التام دون أن يكتفها لبس أو غموض من خلال الاعتماد علي ألفاظ حاسمة وقاطعة وليست فظفاظة بما يجعلها محلا لتأول أو الجدال من قبل الطرفين ، ولعل الهدف المرجو من وراء تحديدها يكمن في تجنب الطرفين الدخول في نزاع بشأنها وهو ما يمنحهم فرصة اللجوء إلي إعادة التفاوض بشأن بنود العقد حال تحققها ليتم مراجعة بنود العقد في محاولة منهم إعادة التوازن العقدي المفقود إليه وفقا للظروف التي تحيط بالعقد وقت

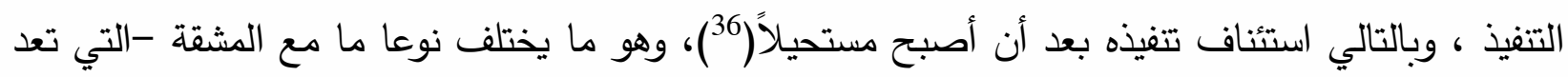
نوعا من أنواع القوة القاهرة - التي يصبح معها التنفيذ شاقًا وليس مستحيلاً خاصة مع ما تتسم به القوة القاهرة من خاصية خروجها عن إرادة الأطراف فلا دخل لهما بحدوثها ، وهو ما استقرت عليه أحكام محكمة النقض المصرية جينما قررت أن :" ذلك إذن انفراد الدائن بالخطأ أو استغرق خطئه خطأ المدين بحيث كان هو السبب 
المنتج للضرر - يسقط حق الدائن في التعويض " (373) ، كما أنها لا تقع تحت حصر بل كل حدث تتوافر به الثروط يصلح ان يكون قوة قاهرة تلقائيا. - شرط السرية وعدم المنافسة : إذ يعد شرط السرية من الثروط الهامة بالنسبة لعقود التجارة الدولية خاصة

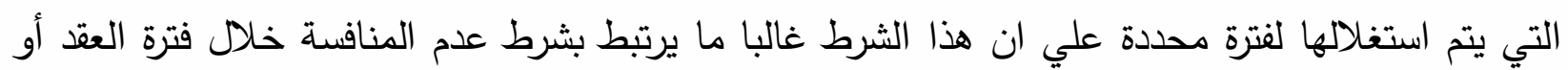
اللاحقة علي انتهائه . - مراجعة العقد : يتم إدراج هذا البند في العقد ليتيح للطرفين الحق في تعديل العقد بعد إبرامه وذلك بتعديل بنود

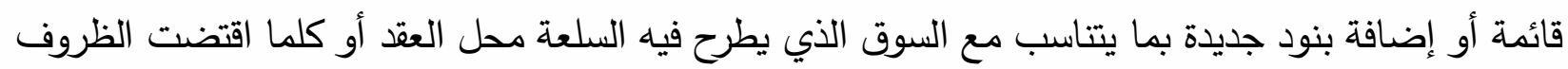
ذلك.

علي أن هذه البنود لا تشكل في حد ذاتها بنودًا إلزامية بل هي مجموعة بنود استرشادية لا يلتزم بها الأطراف في العقود المبرمة ، فأيا كان نوعها أو موضوعها فإن تلك العقود تتفق حول مجموعة من الالتزامات يقابلها مجموعة من الحقوق ، وهو ما يتيح لأحد الأطراف اتخاذ الاجراءات اللازمة لحماية حقه حال اخلال الطرف الآخر بأداء التزاماته ، فله أن يتوقف عن دفع المبلغ المتفق عليه حال توقف الطرف الآخر عن توريد السلع أو أداء الخدمة المتفق عليها . مع الأخذ في الإعتبار أنه ليس كل توقف يمنح الطرف الآخر الحق في اتخاذ الاجراءات فقد يحدث ذلك خلال فترة قصيرة - لا يمكن اعتباره توقف عن التنفيذ وفقا للعرف السائد في المجال أو كان التوقف نتيجة إخلاله في الوفاء بالتزاماته للطرف الآخر - لذا لا يكون هنالك مناصا من الرجوع إلي بنود العقد للوقوف علي مدي تحمله المسئولية عن ذلك من عدمه ، فمثلا حدوث قوة قاهرة تحول دون وفاء أحد الأطراف بالتزاماته وهو ما لا يعد إخلال منه ببنود العقد بما يستوجب معه تحمله التعويض الناجم عن الضرر الناجم عن توافر المسئولية العقدية عن عدم تتفيذ العقد المبرم بينهم ما لم يوجد نص خاص أو اتفاق علي ذلك ، وهو ما ينطبق بشأن تثشي وباء الكورونا في العالم الذي صاحبه تسارع أعداد الوفيات وغلق الحدود بين الدول وتوقف العمل والصناعة بدول العالم ، فإذا كان موضوع أحد عقود التجارة الدولية هو توفير سلعة معينة فإن المتعاقد يواجهه عدة صعوبات في التتفيذ بداية بتصنيعها و مرورا بنقلها داخل حدود الدولة الواحدة وانتهاء بنقلها إلي الدولة المتقق عليها بالعقد ، أما إذا كان موضوع العقد هو إنثاء مقاولات أو نقل للتكنولوجيا فإنه يكون من الصعب علي الشركة المورده أن تفي بالتزاماتها لتوقف العمل داخل حدود الدول وخارجها ، ونظرا لتأثير مثل هذه الاحداث علي تتفيذ عقود التجارة الدولية وعلي وفاء الطرفين بالتزاماتهم التبادلية فإنه هناك 
مجموعة من الشروط يجب توافرها لانتفاء المسئولية ورفعها عن كاهل الطرف المتقاعس عن البدأ في التنفيذ أو مواصلته وهو ما سنتاوله باستفاضة في المبحث الاول ،فإذا ما تحققت الشروط في الحدث ونتج عنه عدم التوقع وعدم إمكانية الدفع واستحالته(38) هنا يحق لطرفي العقد أن يلجاءا إلي إعادة التفاوض - وذلك استنادا إلي بنود العقد وفقاً لشرط "إعادة التفاوض " أو نزولا علي رغبة الطرفين - والتي يكون من أهم إنجازاتها هو إعادة التوازن العقدي لعقود التجارة الدولية وذلك إذا لاح في الأفق لأطرافها أن هناك فرصة يجب اغتنامها لحل كافة المشكلات التي تواجه التنفيذ وذلك استنادا إلي مبدأ حسن النية بين الطرفين (193) أو أن يري الطرفين أن لا مناص من كتابة النهاية المحتومة للعقد لاستحالة تتفيذه لانتشار فيرس كورونا ، وهو ما سنتناولة في المبحث الثانى ، وذلك وفقا لاتفاقية الأمم المتحدة بشأن عقود البيع الدولي للبضائع 1980 و مباديء اليونيدروا(40) ، وذلك في محاولة منا لفهم هذه العلاقة ووضع الإطار القانوني الذي يمكن أحد طرفي هذا النوع من العقود - خاصة من الدول النامية - من فهمها بما يساعده علي تجنب ذلك مستقبلاً .

\section{المبحث الاول}

\section{الإعفاء من المسئولية الناجمة عن الإخلال ببنود عقود التجارية الدولية خلال انتشارفيرس كورونا}

إذا كانت القوانين الوطنية قد وضعت حدودا لكافة التصرفات التي تكون محلا لإبرام العقد بحيث إذا ما خالف أحد اطرافه هذه الحدود ونتج عن هذه المخالفة ضررا بالطرف الآخر جاز له الرجوع عليه ، للحصول علي التعويض الذي يساعده في التغلب عليه و تخطيه وهو ما يعرف بالمسئولية العقدية (41)،فإن الاتفاقيات الدولية لم تكن منها ببعيد إذ

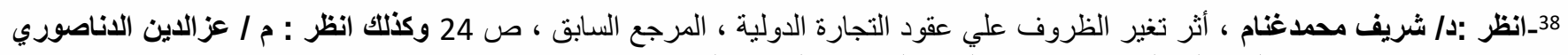

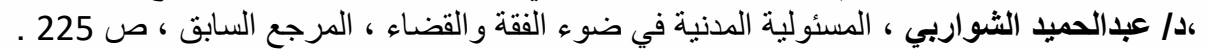

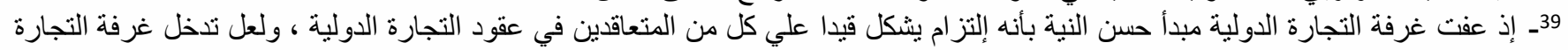

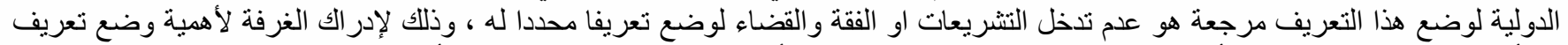

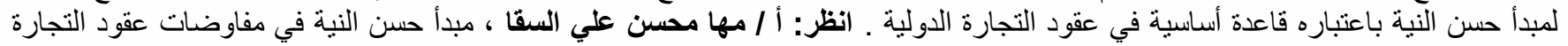

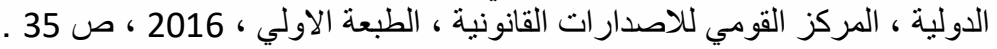

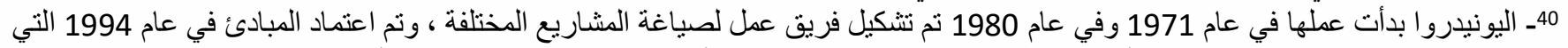

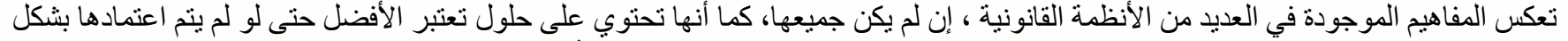

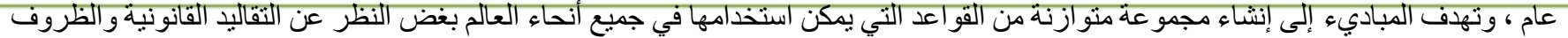

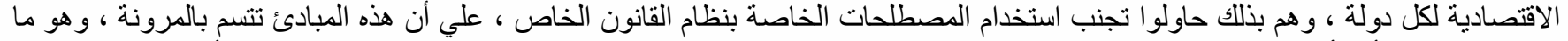

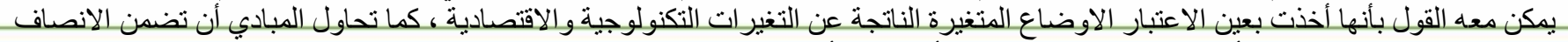

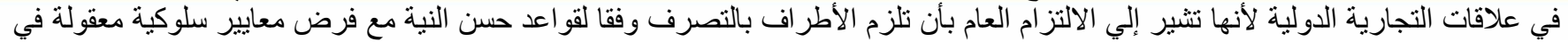

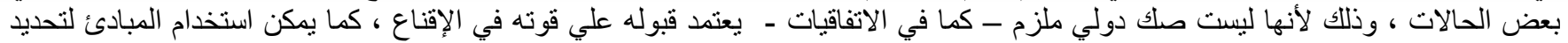

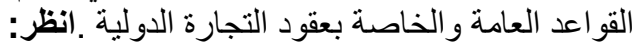

Gagné (L) , Les contrats commerciaux internationaux et les systèmes de droit civil et de common law, op.cit.p.51. 41 انظر : م / أعزالدين الدناصوري ،د/ عبدالحميد الشواربي ، المسئولية المدنية في ضوء الفقة و القضاء ، المرجع السابق، ص 386 وما بعدها 
تبنت ما سارت عليه القوانين الوطنية في نطاق عقود التجارة الدولية ، إذ يلتزما طرفا العقد تتفيذ تعهداتهم من خلال وفاء البائع بالتزاماته قبل المشتري لنصبح بصدد تتفيذًا مطابقا لما تم الاتفاق عليه بالعقد ، وبالتالي فإن أي تقصير في التتفيذ وفقا لبنوده يحق لأحد أطرافة أن يلجأ الي القضاء لإلزام الطرف المخالف في التتفيذ بالتعويض حتي وإن لم يؤدي إلي إلحاق الضرر بالطرف الآخر و هو مالا يقل اهمية عن مسئوليته عن جبر الضرر الذي لحق بالمضرور (42)

لكن لا يمكن الاعتماد علي ما سبق كمبدأ عام يطبق علي كافة حالات عقود التجارة الدولية التي تتميز بالاتساع وطول فترة تتفيذها مما يمكن معه الحديث عن تعرضها لأحداث مفاجئة وغير متوقعة محل اعتباربحيث يصبح معه تتفيذ العقد غير ممكنَ بل ومستحيلاًباعتبارها قوة قاهرة حالت دون تتفيذه كما في حالة انتشار فيرس كورورنا(43)، و الذي اجتاح العالم وما تبع ذلك من اجراءات احترازية من حظر للتجول الكلي وتوقف حركة الملاحة بين الدول وهو ما كان له بالغ الاثر علي قيام العقد واستمراه بين أطرافه بل وعلي قدرة الأطراف علي تحمل المسئولية القانونية (44)عن إخلالهم في

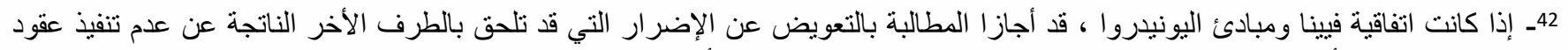

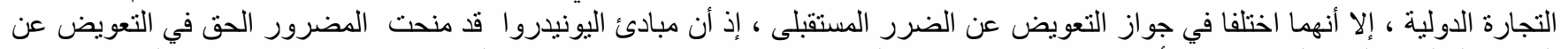

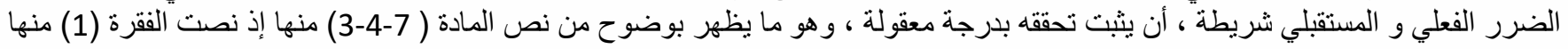

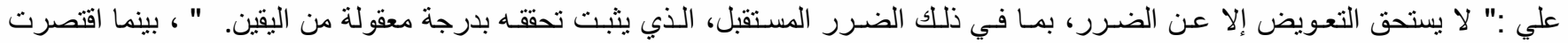

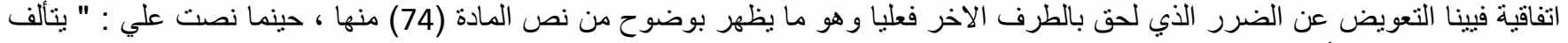

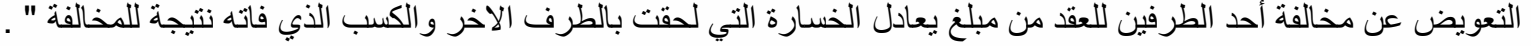

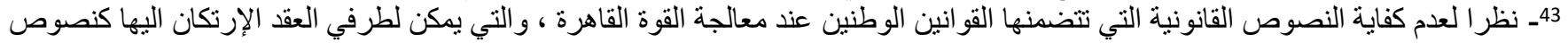

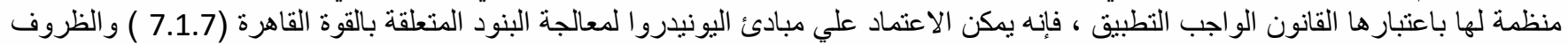

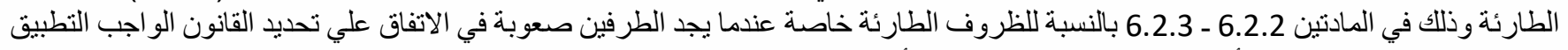

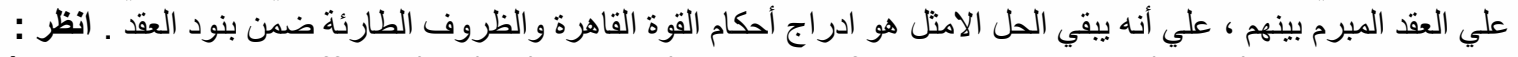
Guillaumond (R) , La gestion des difficultés d'exécution résultant de force majeure ou d'imprévision , Colloque International Alger 26 mai 2014, ADAMAS , P.34.

https://www.adamas-lawfirm.com/upload/pdf/publications/707c59312ad17da1ac2b01e.pdf

Bamdé (A), La responsabilité contractuelle: régime juridique, op.cit. وكذلك : 44- تنقسم المسئولية القانونية في قانون التجارة الدولية الي:

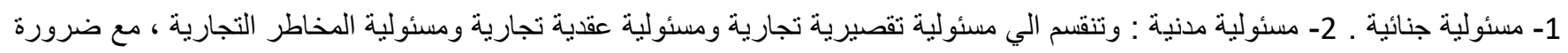

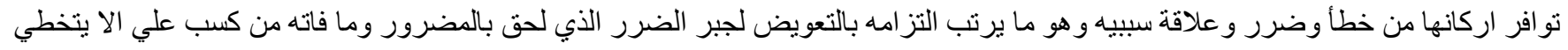

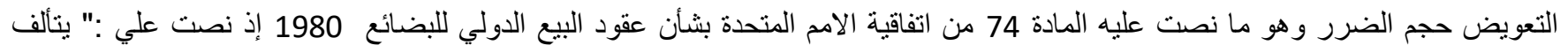

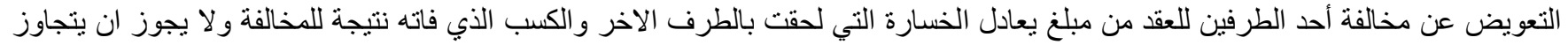

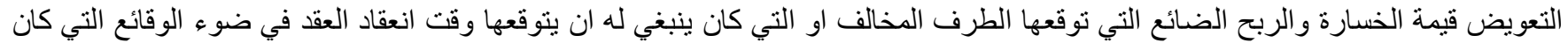

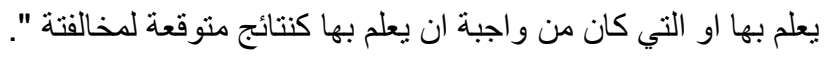


الوفاء بالتزاماتهم قبل بعضهم البعض نتيجة توقف الحياة الصناعية والتجارية مما قد ينشأ عنه التزامه بتعويض الطرف الآخر ، رغم استعداده الكافي لتنفيذ بنودها ، إذ أدي فرض حظرا التجول إلي توقف حركة التنقل والإنتاج، وهو ما يشكل عائق يحول دون تتفيذ العقود المبرمة خلال الفترة السابقة علي انتشار فيرس كورونا وهو ما سلب إرادة أطرافه في وضع انتشار الفيرس موضوع النقاش خلال فترة المفاوضات التي تجري قبل إبرام العقود ، خاصة مع عدم توقع حدوثه بما يمنح الأطراف الفرصة الكافية لمعالجة كافة ما يعتري التنفيذ من قصور أو مشكلات قد تتجم عن انتثار هذا الفيرس، ولعل ذلك قد يشكل إرهاقا كبيراً لأطرافه بما ينشأ عنه استحالة في التتفيذ نتيجة عجز قراتهم علي استيعاب هذا الخلل و تحمل تبعاته واستمرارهم في ممارسة التجارة ، ولعل ذلك هو ما دفع الرئيس الصيني شي جين بينغ في 23 فبراير 2020 إلي التصريح أن انتشار الفيروس التاجي الجديد هو أزمة صحية عامة يمكن أن تشكل خطرًا كبيرا على الاقتصاد الكلي لوقف أنثطة الإنتاج ، وانقطاع حركة الناس وقطع سلاسل التوريد . وهو ما انتبه إليه المشرعين الوطني والدولي منذ زمن ليس بالقريب إذ تدخل لوضع شروط لإعفاء الأطراف المتعاقدة من تحمل مسئولية التعويض عن عدم تتفيذ عقود التجارية الدولية حال حدوث قوة قاهرة- وهو ما تحقق بانتشار فيرس كورونا المستجد-وثبوتها بمايحول دون تتفيذه بقوة القانون دون الحاجة إلي اتفاق الطرفين وهو ما يختلف عن شرط إعادة التفاوض (45)، ونظرا لأن الجراح التجارية التي قد يتعرض لها أحد طرفي العقد أو كلاهما نتيجة هذا التوقف قد توصف بالغائرة بل والمميتة في بعض الأحوال فقد وضع المشرعين الوطني والدولي شروطا قاسية لتطبيقها علي عملية التوقف أو الامتناع عن التنفيذ العقدى أو أحد بنوده الجوهرية باعتبارها سياج يحمي طرفا العقد ، لذا اشترطا المشرعين الوطني والدولي أن يمثل عائقا(46) خارج عن إرادة طرفي العقد مما يحول دون تنفيذه ويستوي في ذلك أن

45- إذ أن القوة القاهرة تتطبق تلقائيا دون الرجوع الي بنود العقد المبرم ولعل ذلك مرجعه هو اختلاف الاساس الذب تستمده منها كلا من القوة القاهرة

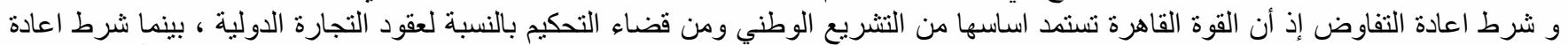

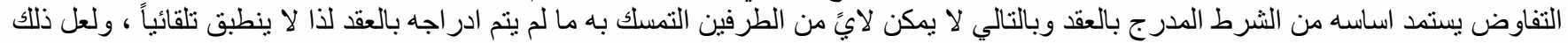

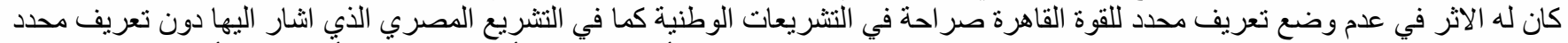

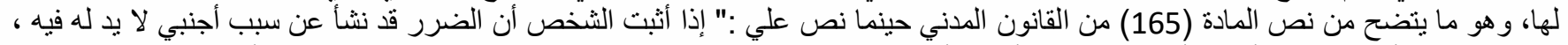

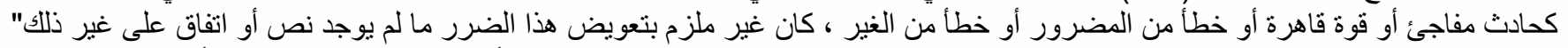

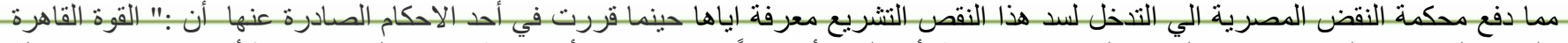
بالمعنى الو ارد في المادة 165 من القانون المدني تكون حربًا أو زلز الا أو حريقًا، كما قد تكون أمر إداريًا واجب التتفيذ، بشرط أن يتو افر فيها استحالة

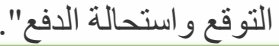

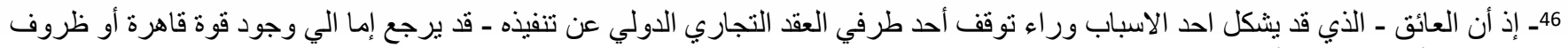

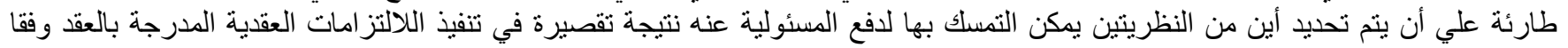

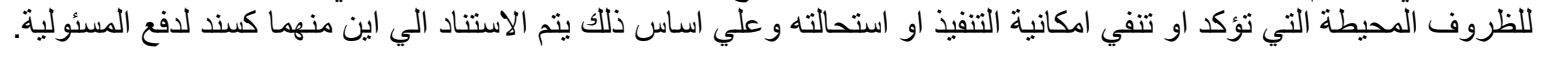


يكون العائق مؤقتا أو مطلق (المطلب الاول )(47)، كما اشترط استحالة دفع الحدث وعدم توقعه عند إبرام العقود وإلا كان بمقدور الطرفين تخطيه والبحث عن حلا له في مرحلة المفاوضات، وبالتالي ينتفي عامل المباغتة التي لم تكن في حسبان طرفي العقد بما يمنحه الوقت الكافي لإمكانية دفعه (المطلب الثاني )، علي أن ينشأ عن ذلك خللاً في التوازن العقدي لعقود التجارة الدولية المبرم وهو ما سنتناوله باستفاضه .

\section{المطلب الاول}

\section{اعتبار فيرس كورونا المستجدعائق أمام تنفيذ عقود التجارة الدولية}

لاعتبار فيرس ما عائقا يحول دون تنفيذ أحد عقود التجارة الدولية ، كان لابد من الرجوع إلي منظمة الصحة العالمية المسئولة عن اعتبار انتشار مرضا ما وباءًا عالميا من عدمه (48) ، إذ وضعت منظمة الصحة العالمية معايير وقواعد محددة لإدراج مرض محددا ضمن الأمراض التي تعد وباء عالميا يمكن أن تعلن علي إثرها حالة الطواريء الصحية ، والتي بموجبها يمكن للمنظمة أن تضع مجموعة من الإرشادات العامة التي يترك أمر الالتزام بها من عدمه إلي الدول الاعضاء فيما يتعلق بالجانب الصحي فقط دون أن تطرق إلي الإجراءات الاقتصادية التي تلتزم باتباعها الدول في هذا الثأن ، وهنا لا تملك الدول الأعضاء إلا ان تتكاتف فيما بينها لمواجهة هذا الوباء العالمي من خلال الاتفاق علي اتخاذ كافة التدابير اللازمة لمواجهة هذا الوباء بالانصياع لتوجيهات منظمة الصحة العالمية بخصوص الإجراءات المتبعة لمنع تقشيه بإنذار الدول باعتباره وباءً عالميا وذلك في 30 يناير 2020 -وهو ما عاد و أعلنه المدير العام

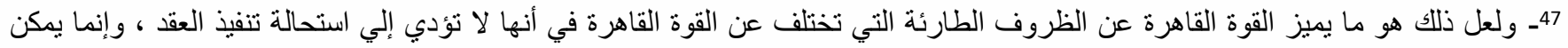

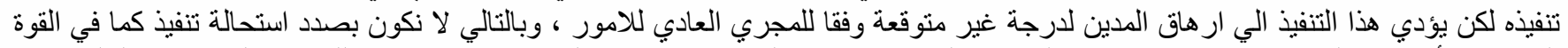

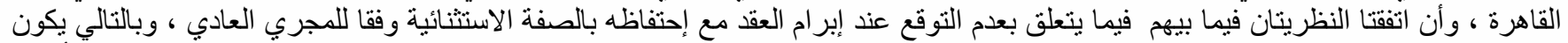

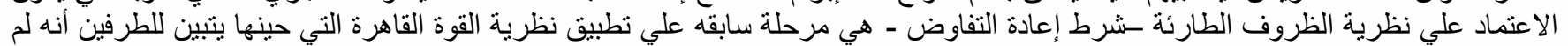

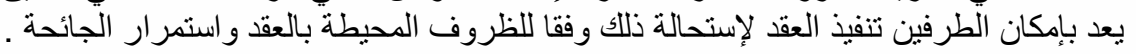

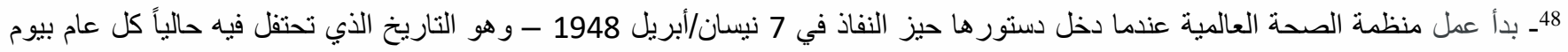

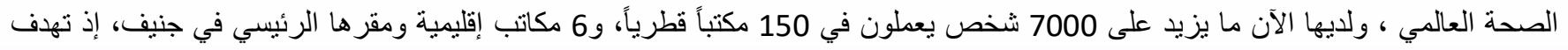

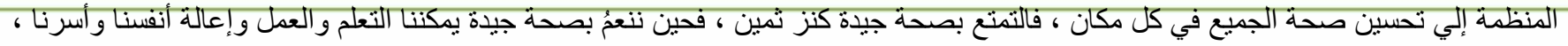

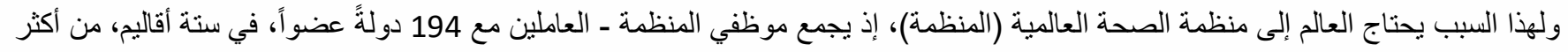

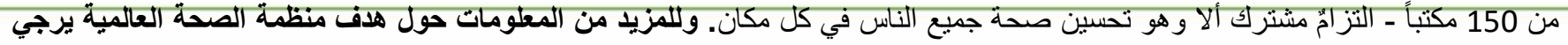
مراجعة موقعها الرسمي : https://www.who.int/ar/about/what-we-do/who-brochure 
لمنظمة الصحة العالمية تيدروس أدهانوم غيبريسوس يوم الأربعاء الموافق (11 مارس/ آذار 2020) أن المنظمة التابعة للأمم المتحدة باتت تعتبر فيروس كورونا المستجدّ المسبّب لمرض "كوفيد-19" والذي يتفشّى في مختلف أرجاء المعمورة "وباءً عالميا - (49) ، وهو التاريخ الذي يمكن أن نعول عليه في إعلان ظهور الفيرس بما يحمل بين جنباته من آثار قانونية تأثر بشكل مباشر علي عقود التجارة الدولية(50) فعليه يتوقف تحديد قيام مسئولية طرفي العقد عن عدم تنفيذه من عدمه ، فإذا كان العقد المبرم سابق علي انتشار الفيرس بما يمكنه من دفع المسئولية لانتفاء شروطها في الحدث فلا يحق للطرف الآخر المطالبة بالتعويض عن عدم التنفيذ وهو ما ينتفي حال إبرام العقد في تاريخ لاحق علي إعلان فيرس كورونا وباءً عالميا ، ولعل ذلك هو ما أخذت به أحد المحاكم الفرنسية (151) حينما اعتبرت أن المستأنف الذي يطالب بتأجيل تتفيذه مستتدا إلي توافر القوة القاهرة ليس علي حق ، وذلك تأسيسا علي العرض المقدم منه بالتعاقد قد تم بتاريخ لاحق علي 30 يناير 2020 الذي أعلنت فيه منظمة الصحة العالمية عن جائحة كورونا وكذا إعلان كلا من إيطاليا وفرنسا عن إجراءات قسرية تتعلق بالجائحة غير أن هذه الإجراءات القسرية لم تمنع من إمكانية تاسيس الشركة التي تم الاتفاق علي شرائها لاصول الشركة المستانف ضدها .

فبعد هذا الإعلان بدأ العالم يعي خطورة هذا الوباء جيدا وما يحصده من أرواح ، فلم يعد أمام الدول سوي الاصطفاف من أجل مواجته باتخاذ مجموعة من التدابير الوقائية والاحترازية تهدف إلي وقف نزيف العدوي المرعبة لهذا الوباء وانتقالة بسرعة البرق بين دول العالم ، فكان لابد من اتخاذ نوعين من التدابير الأولى تدابير علي المستوي الوطني والثانية علي المستوي الدولي ، لنشهد بهذه التدابير عالماً معزولا يتحول إلي قري معزولة عن بعضها خاوية علي

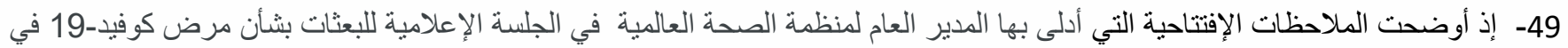

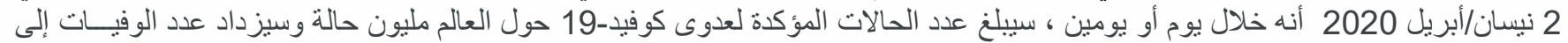

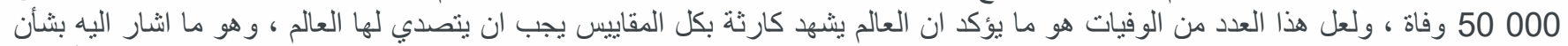

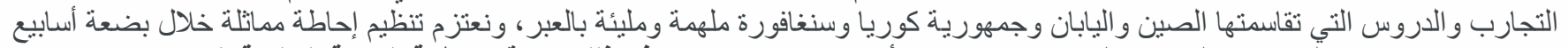

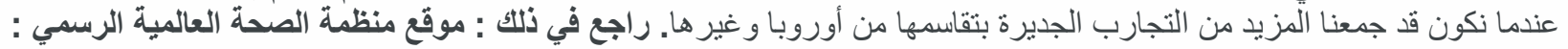
https://www.who.int/ar/dg/speeches/detail/who-diret-the-mission-briefing-on-covid-19---2-april-2020 وكذا الرجوع الي الموقع التالي للاطلاع علي تصريحات المدير العام لمنظمة الصحة العالمية : https://www.dw.com/ar/\%D9\%85\%D94\%D9\%85\%D9\%8A\%D8\%A7/a-52726143

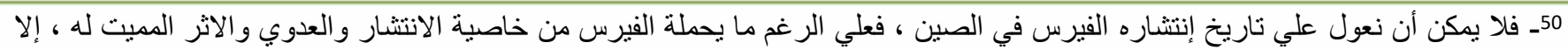

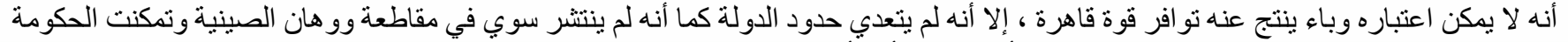

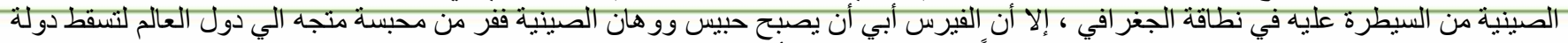

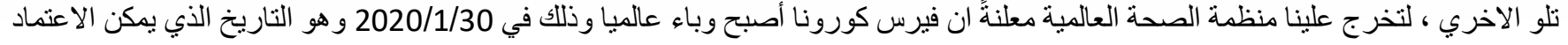

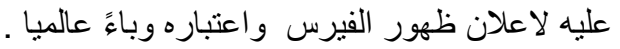
:

Cour de appel de nancy- ch. Commercial -5 Mai 2020- $n^{\circ}$ 20/00748 
عروشها وكانها بيوت الأشباح ، مما كان له بالغ الأثر علي اقتصاديات الدول لتقع الدول بين مطرقة الوباء وسنداب اقتصادها المهدد بالانهيار، إذ تلتزم الدول باتخاذ كافة التدابير الموضوعية ( أي القيود المفروضة علي حركة الأنشطة الاقتصادية و الأشخاص) لحماية رعاياها من تقشي هذا المرض بينهم من جهة و من جهة أخري تلتزم بحماية اقتصادها الوطني من التعرض للانهيار نتيجة الكساد(25) ، فلا أسواق تقام ولا مصانع تعمل فالحياة معطلة وقد أصيبت بالثلل التام ، وهنا كانت الضائقة الكبري التي تعرض لها أطراف عقود التجارة الدولية التي يقع علي كاهلهم مجموعة من الالتزامات يصعب الوفاء بها في هذه الحالة وهو ما يعد عائقً يحول دون تتفيذ العقد .

وهنا يجد طرفي عقود التجارة الدولية أنفسهم عاجزين عن وقف نزيف الخسائر التي يمنون بها نتيجة توقفهم عن مواصة تنفيذ بنود العقود المبرمة فلا يملكون مواصلة التتفيذ ولا يملكون التوقف عنه ففي كلتا الحالتين خسائر لا يمكن استيعابها فلا ملجأ ولا منجي لهم سوي الرجوع إلي بنود العقد والاتفاقيات الدولية للوقوف علي اعتبار فيرس كورونا- الذي وصف بالجائحة(53)|التي تجتاح العالم و باعتباره وباءً عالميا - عائق يمنع تتفيذ عقود التجارة الدولية- فالعائق يستغرق القوة القاهرة أو الحادث المفاجئ أو أي حادث مستقبلي يحول دون التتفيذ- وذلك لاعتباره عائق أمام الأنشطة الاقتصادية ، وهو ما أكد عليه العديد من المسئولين والخبراء الاقتصاديينخاصة وأن أي توقف للحياة الاقتصادية في دولة ما قد يؤدي بالتبعية إلي توقف صناعة مرتبطة بها في دولة أخري ، وهو ما قد يعد سندا لانتفاء المسئولية عن عدم تتفيذ العقد أو عن تعويض الطرف المتضرر نتيجة عدم التزام الطرف الاخر ببنود العقد ، وذلك وفقا لاتفاقية الأمم المتحدة بشأن البيع الدولي للبضائع و مباديء اليندروا وهو ما يمكن معه اعتبارها قوة قاهرة، علي أن أثار القوة القاهرة علي العلاقة

\footnotetext{
UNCTAD, Global trade impact of the coronavirus (COVID -19) epidemic , 4MARCH 2020 ,P.4 .
}

53ـ فالجائحة هي وباء ينتشر على نطاق شديد الاتساع يتجاوز الحدود الدُوليَّة ، مؤثرًا -كالمعتاد- على عدد كبير من الأفراد، قد تحدث الجو ائح لنؤثر على البيئة والكائنات الزر اعية من ماثية ومحاصيل زر اعية و الأسماك و الأشجار و غير ذلك ، وقد قسمت منظمة الصحة العالمية دورة حدوث الجوائح

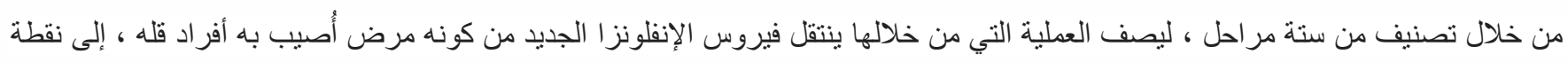

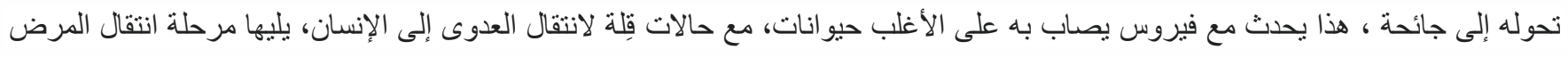

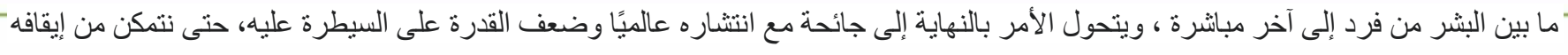

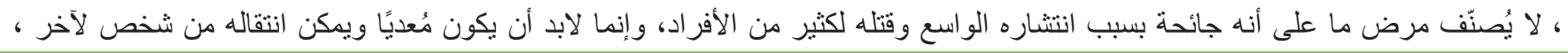

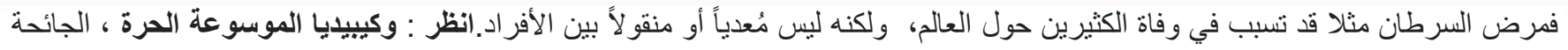

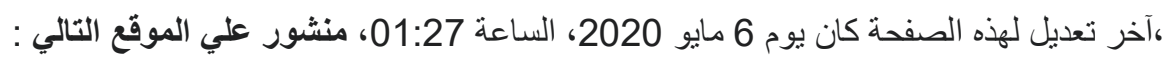
https://ar.wikipedia.org/wiki/\% 8\%A7_(COVID-19) 
التعاقدية غير قاصرة علي ما سلف ، وإنما غالبا ما يتم تتاولها بوجه عام في بنودالعقود المبرمة كالالتزام بإبلاغ المشارك في غضون فترة معقولة وتعليق الخدمات أو الالتزام بالتفاوض وفقا لمبدأ بحسن نية بشأن الترتيبات المكنة لتعليق التتفيذ أو الإنهاء ، وهي جميعها أمور تكون محل بحث من القاضي في العقد عند قيام نزاع في هذا الثأن بين الطرفين(54).

تجدر الإشارة إلي أن اختلاف الاتفاقيات الدولية والتشريعات الوطنية في الألفاظ المستخدمة لتدليل علي وجود مانع يحول دون التنفيذ فالبعض استخدم لفظ عائق والبعض الآخر استخدم الحادث المفاجئ أو القوة القاهرة وإن كنا نرى أن كلمة عائق هي أشمل من القوة القاهرة والحادث المفاجئ والظروف الطارئة ، اذ يستغرقهم جميعا كما انهم انواع للعائق وهو ما يسمح بادراج اي مانع يمثل عائق أمام التنفيذ ضمن الموجبات لانتفاء المسئولية فلكل من هذه التسميات شروط يجب توافرها لانتفاء المسئولية عن طرفا العقد حال تحققها شريطت خروجهم جميعا عن إرادة طرفا العقد ، ولعل ذلك هو ما يظهر بوضوح من نصوص اتفاقية الامم المتحدة بشأن البيع الدولي للبضائع 1980 التي تعرضت لحالة عدم تتفيذ العقد لوجود عائق يعود إلي ظروف خارجة عن إرادته دون الن تحدد الاتفاقية نوع هذا العائق وعما اذا كان قوة قاهرة أو ظروف طارئه وما إذا كان مؤقتا أو يستمر لفترة طويلة وينتهي أم أن هذا العائق سوف يستمر لدرجة تحول دون التنفيذ مطلقا لنصل بالعقد الي طريق مسدود يؤدي علي إثر ذلك إلي إنهاء العقد ، فإن كانت الاتفاقية لم تحدد نوع العائق كما لم تسميه - لم تضع له تسميه محدده - وهو ما يسمح بإدراج كافة العوائق التي قد تحول دون التنفيذ سواء القائم منها حاليا وما يمكن أن يستجد في المستقبل ، ولعل ذلك مرجعه هو ما تتميز به الحياة التجارية من سرعة وتيرتها وما يرتبط بطبيعة القواعد القانونية الدولية التي تعتمد علي ما يفرزه الواقع العملي من قواعد جديدة تختلف من نشاط لآخر ، وهو ما يظهر بوضوح من نص المادة (79) من الاتفاقية سالفة الذكر حينما نصت علي :" لا يسأل أحد الطرفين عن عدم تتفيذأي من التزاماته إذا أثبت أن عدم التتفيذ كان بسبب عائق يعود إلي ظروف خارجة عن ارادته وانه لم يكن من المتوقع بصورة معقولة أن يأخذ العائق في الاعتبار وقت انعقاد العقد أو أن يكون بإمكانه تجنبة أو تجنب عواقبه أو التغلب عليه أو علي عواقبة " .

54ـ انظر : م / عزالدين الدناصوري ،د/ عبدالحميد الثواربي ، المسئولية المدنية في ضوء الفقة والقضاء ، المرجع السابق ، ص 227

وكنلك انظر :

Berg-Moussa (M) , Le Coronavirus est-il un cas de force majeure et/ou une cause d'imprévision ?, 04/03/2020. https://www.august-debouzy.com/fr/blog/1415-le-coronavirus-est-il-un-cas-de-force-majeure-etou-une-cause- 
ووفقا لما سلف فإنه يمكن إدراج فيرس كورونا المعدي تحت ما أسمته الاتفاقية " عائق " إذ أن الاتفاقية لم تضع معيارا معينً أو تعريفا محددا يمكن الرجوع إليه للوقوف عما إذا كان الحدث الذي ترتب عليه التوقف عن الوفاء بالتزاماته يندرج ضمن مصطلح عائقً الوارد ذكره بالمادة 79 من الاتفاقية من عدمه ، وهو ما جعلها تتسم بالمرونة في تحديد الأفعال التي يمكن اعتبارها عائقا أمام التنفيذ ، وبالتالي فإن أي حدث يمكن أن يؤدي الي التوقف عن الوفاء يمكن اعتباره عائقَ شريطة توافر كافة الشروط الأخري الوارد ذكرها بالمادة سالفة الذكر ،وهو ما يسمح باعتبار فيرس كورونا عائقا لا يستوجب مسالة الطرف المتوقف عن التنفيذ خاصة بعد إعلان منظمة الصحة العالمية باعتباره وباء يجتاح العالم لارجة اعتبرته المنظمة " جائحة صحية " خاصة مع ما يتسم به المرض من انتشار غير مسبوق وما يحمله من جينات مبهمه وما يمثله من قفزه نوعية في الفيروسات المعدية لذا لم يستطع العلماء فك شفرته بما يمكنهم من التوصل الي علاج ناجع له إلي الآن ، إذ استمرت الفاجعة لفترة تتخطي 6 اشهر ليقف العالم عاجزا أمامها وهو ما يمكن أن يؤدي إلي تعرض اقتصاده لكساد عالمي مما قد يؤدي إلي اعتبار الظروف المالية أو الاقتصادية الناتجة عنه عائق ، لذا يمكننا القول بان فيرس كورونا يحمل في طياته مجموعة من العوائق تصلح جميعها لان تكون أحد الاسباب وراء التوقف عن الوفاء بالالتزامات العقدية وخاصة ما يتعلق منه بالإنشاءات ونقل التكنولوجيا وهي عقود عابرة للحدود وتستمر لفترة طويلة قد تمتد لسنوات.

يأتي ذلك علي الرغم من عدم اعتبار الفيرس خارجا عن المدين الذي تأثر به - فهو فيرس يحمله المدين وغيره- ، إلا أنه يجب التأكيد علي أن الفيرس هو أمر خارج عن إرادة المدين فلم يسعي إلي اختراقه للاجسام ، فمن طبيعة هذا الفيرس أنه معدي يتناقل بين البشر دون تدخل من قبل أحد منهم، فالصعوبات الواضحة في التمييز بين الطابع الخارجي أو الداخلي للحدث هى ما تبرر تعريف الحدث الذي يستتد إلي مفهوم السيطرة من قبل المدين(55).

علي أنه يجب لتحقق الإعفاء من المسئولية أن يتوافر عدة شروط في العائق ، ترتبط به وجودا وعدما ، بمعني أن انتشار فيرس كورونا - باعتباره عائق - وحدة غير كافي لهذا الإعفاء بل يجب أن يلحق وجودة مجموعة من الإجراءات

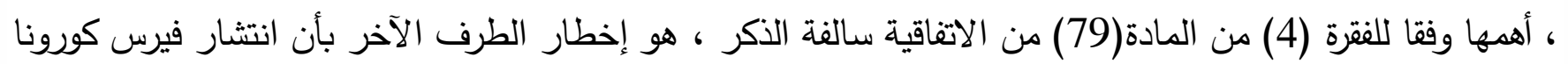

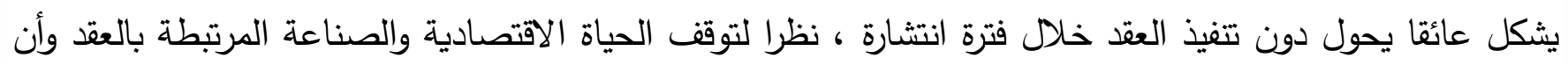
حدود الدول قد تم إغلاقها لحصار الوباء وانه سيتم استئناف تتفيذ العقد بمجرد انجلاء الوباء عن البلاد ، وهو ما يظهر فيدر

Gastebled (É), Le clair-obscur de la force majeure en matière contractuelle face au Covid-19,op.cit . 


\section{منى عمار}

بوضوح من نص الفقرة (4) سالف الإثارة إليها حينما نصت علي :" يجب علي الطرف الذي لم ينفذ التزاماته أن يوجه إخطارا إلي الطرف الآخر بالعائق وأثره في قدرته علي التنفيذ "، واشترطت الاتفاقية أن يتم هذا الإخطار خلاد

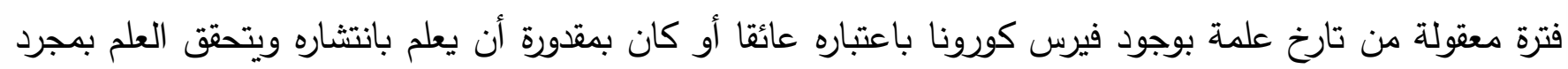

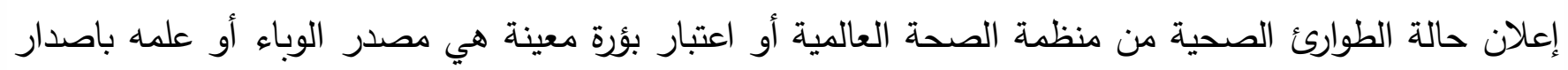

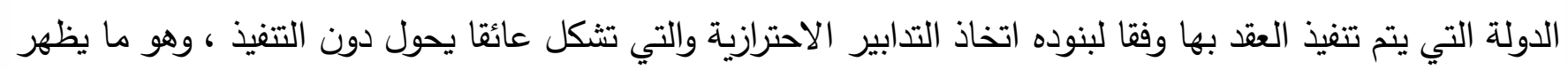

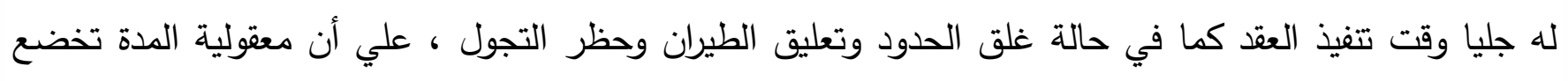

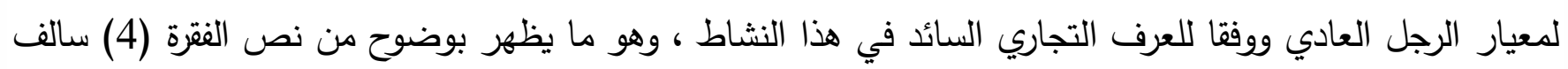

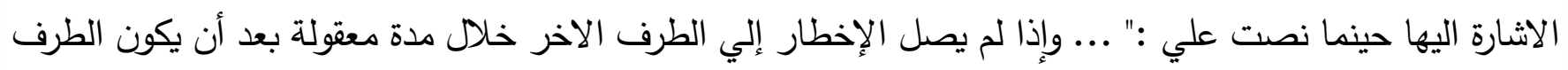

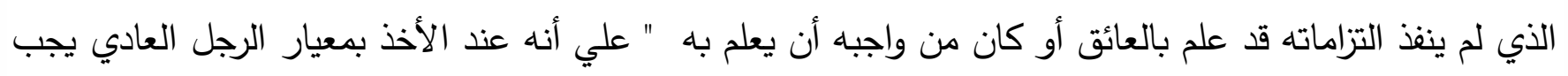

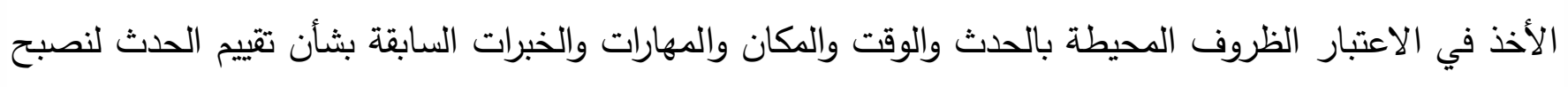
في النهاية عند تقييمه بصدد أمر نسبي بما يحمله من درجه عالية من عدم اليقين بشأنه ، وهو ما يمكن معه القول

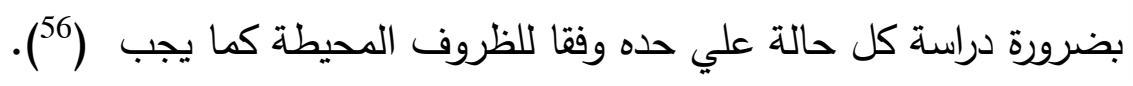

وعليه فإن الطرف الذي لم ينفذ التزامه يُسأل عن عدم التتفيذ اذا لم يتخذ الاجراءات التي تتاولتها الاتفاقية وفي الوقت الدحدد ، ولعل ذلك مرجعه هو اختلاف مفهوم العائق من مكان لآخر فقد ينتشر الفيرس في دولة ليس لها علاقة بتنفيذ العقد ، وقد ينتشر الفيرس بدولة المتفق علي انها ستكون محطا للبضائع موضوع العقد ، وبالتالي فإن عدم إخطار الطرف الآخر يحمل في طياته معني عدم تعرض البلاد لفيرس الكورونا بما يصبح معه تتفيذ العقد ممكنا ، بما ينتفي معاه توافر العائق في التنفيذ ، لذا يلتزم بتعويض الطرف الآخر عن كافة الأضرار التي تلحق به نتيجة عدم تتفيذه ، كما يعد ذلك تتازلا من الطرف الملزم بالإخطار عن حقه الذي منحته له الاتفاقية في الاستفادة من المكنات التي منحتها لطرفي العقد عند مواجتهم لعائق يحول دون التنفيذ ، وهو ما يظهر بوضوح من نص الفقرة (4) من المادة (79) من

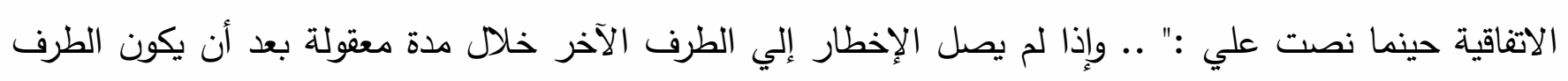

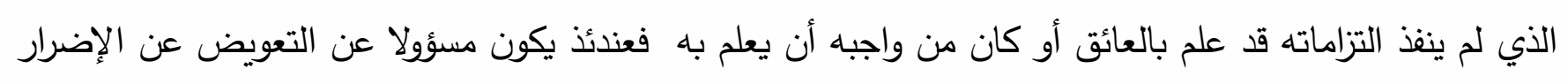

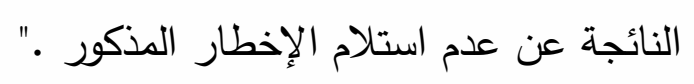

op.cit . : انظر 
هذا ما يتعلق بالبضائع أما فيما يتعلق بباقي أنواع عقود التجارة الدولية والتي تتطبق أيضا علي البضائع فقد تتاولتها بالمعالجة المبادئ التي وضعتها لجنة الامم المتحدة للقانون التجاري الدولي والمعروفة بمبادئ اليونيدروا لعقود التجارية الدولية لعام 2010 ، والتي تتاولت الظروف الثاقة (57)بوضع تعريف لها دون أن يكون هذا التعريف محددا وهو نهج تتبعة العديد من التشريعات والاتفاقيات الدولية عند معالجة التعريفات المرتبطة بها ، بما يمنحها المرونه الكافية التي تساعدها علي التأقلم والتكيف القانوني مع طبيعة الحياة التجارية ، إذ اكتقت بوضع شروط لتحقق انتشار فيرس كورونا بعتباره من الظروف الثاقة معتمدا علي التوازن العقدي في إظهار توافرها من عدمه ، وهو ما يسمح بادخال كافة الأحداث التي قد تخل بصورة أو بأخري بالتوازن العقدي ضمن الظروف الثاقة ووضع لذلك صورتين هما الأولي : إما بأن يتحميل أحد الطرفين أعباء تكاليف التنفيذ نتيجة انتشار الوباء ، وهنا يكون علي أحد الطرفين أن يلتزم بتوصيل البضائع إلي دول مجاورة لدولة التي يتم تتفيذ العقد بها أو يكون مضطرا أن يؤدي الخدمة بصورة مكثفة قبل بداية ساعات حظر التجول علي الأفراد والمنشأت مما قد يتكبد معه أموال طائلة تفوق مجموع ما قد يتحصله من مكاسب مادية عن تتفيذ العقد أو ثانيًا : يؤدي انتشار فيرس كورونا إلي التقليل من حجم الأعباء علي أحد الأطراف بأن يقلل حجم الأعباء المالية عن الطرف المستلم للبضائع أو المتلقي للخدمة بأن يلزم الطرف الآخر بأن يؤدها خلال فترة زمنية صغيرة مقارنة بالمدة المتفق عليها وفي مكان آخر بما يشكل ارهاقا ماليا عليه، علي أن هاتين الحالتين قد جاءتا علي سبيل المثال لا الحصر وهو ما يسمح بإضافة حالات أخرى ، ولا يقتصر الأمر عند هذا الحد بل استوجب توافر عدة شروط مجتمعة في الحدث ليكون محلا للاعفاء من المسئولية ، وهو ما يظهر من نص المادة 6-2-2 من مبادئ اليونيدروا علي :" تتوافر الظروف الثاقة إذا وقعت أحداث تخل بصورة جوهرية بتوازن العقد إما بدفع تكاليف التتفيذ علي أحد الاطراف ، وإما بخفض قيمة ما يتلقاه أحد الأطراف ، ويتعين توافر ما يلي :

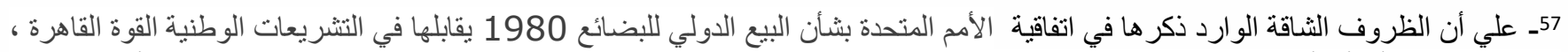

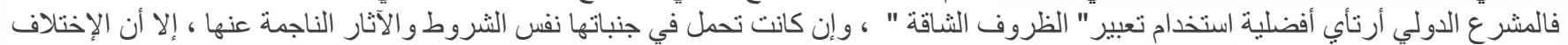

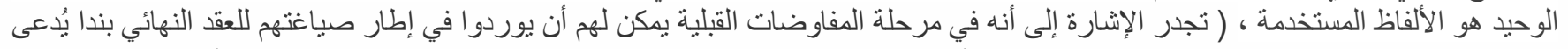

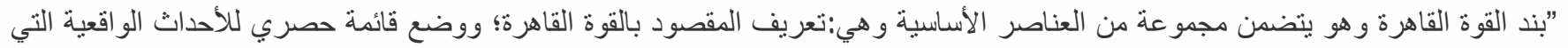

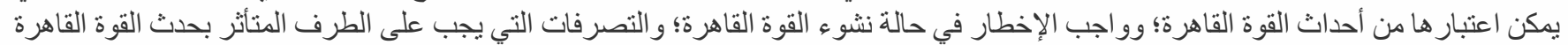

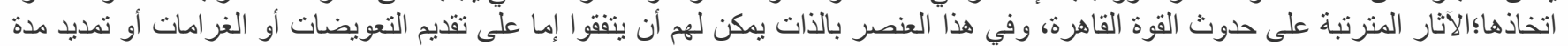

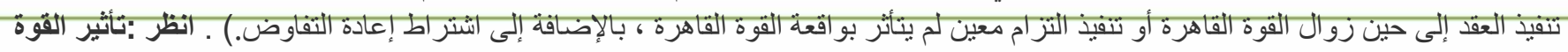

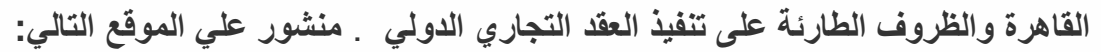
http://www.labodroit.com/\%D8\%A \%B1\%D8\%A6\%D8\%A9-\%D8\%B9/ 
أ ) أن تقع هذه الأحداث، أو يعلم بها الطرف الذي تعرض لها، بعد إبرام العقد

ب) أن لا يمكن أخذ هذه الأحداث في الحسبان بصورة معقولة من قبل الطرف الذي تعرض لها، عند إبرام العقد ج) أن تكون هذه الأحداث خارجة عن سيطرة الطرف الذي تعرض لها د) أن لا يكون الطرف الذي تعرض لهذه الأحداث قد تحمل بخطر وقوع هذه الظروف-. ونظرا لاعتبار فيرس كورونا حدث خارجا عن تدخل أحد طرفي العقد بالإضافة إلي توافر الشروط الأخري التي تطلبتها الاتفاقية في الحدث محل الإعفاء من المسئولية عن التعويض فإنه ينطبق عليه ما ينطبق علي كافة الظروف الشاقة - وفقا لتعريف الاتفاقية - ، لذا تقع المسئولية - عن التعويض عن كافة الأضرار التي تلحق بالطرف الأخر - علي عاتق الطرف الذي يتعدد وضع العاملين لديه في ظروف تؤدي إلي انتشار وباء كورونا ليتمسك به كذريعة لخلق ظروف شاقة يستند إليها لوقف تنفيذ العقد (58)، فعلي الرغم من اعتباره وباءً عالميا ، إلا أنه تعدد استغلال هذا الوباء رغم أنه كان بإمكانه أن يتخذ كافة الاجراءات الاحترازية التي تمكنه من تنفيذ العقد ، إلا أنه لم يتخذ هذه الإجراءات في محاولة منه للاستفادة غير المبررة من الأزمة ، خاصة إذا كان التزامه يقع في دول خارج بؤرة الأزمة والمعلن عنها باعتباره دول منكوبة بفعل الفيرس كإيطاليا وإسبانيا والصين وبريطانيا، وهو ما أكد عليه تقرير الاونكتاد بشأن فيرس كورونا(59)، فاذا كانت الدولة التي سيتم تنفيذ العقد بها عدد محدود في عدد الإصابات وغير معرضة لظروف ما إلي اتساع رقعته أو انتشاره فإنه يمكن القول بإمكانية تتفيذ العقد لكن وفقا لاتخاذ تدابير احترازية ، تجدر الإشارة إلي أن

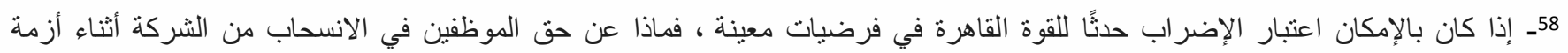

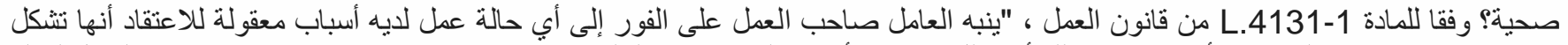

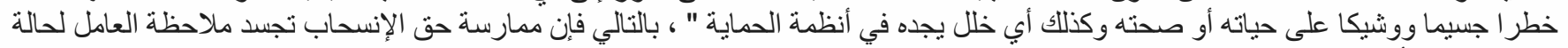

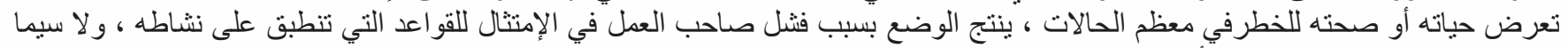

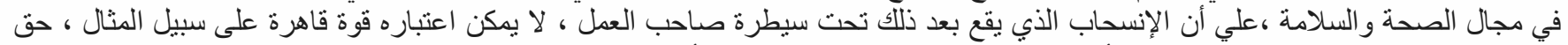

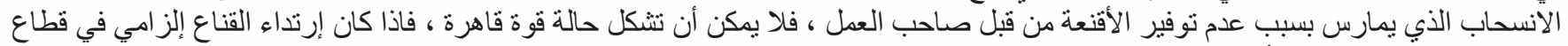

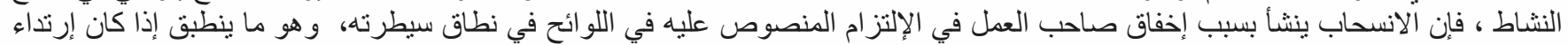

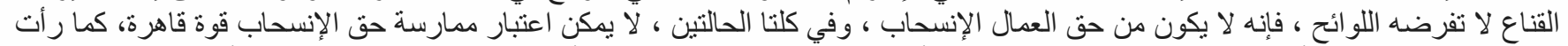

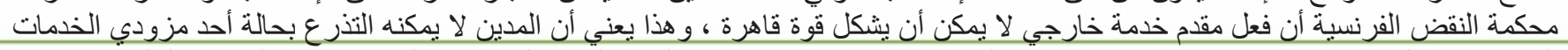

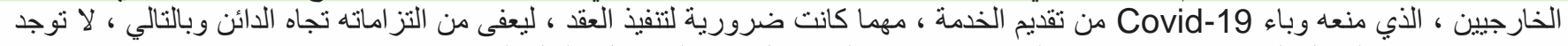

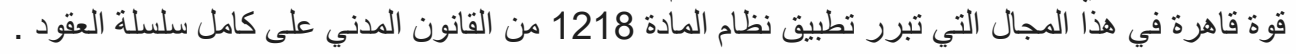

Gastebled (É), Le clair-obscur de la force majeure en matière contractuelle face au Covid-19,op.cit .

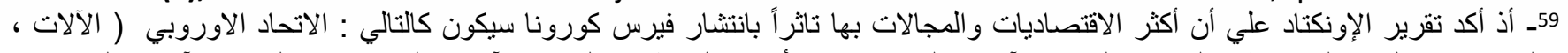

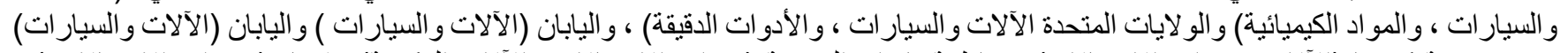

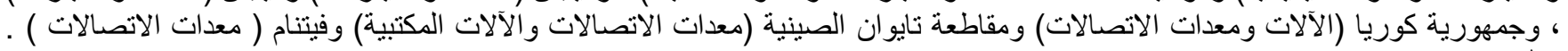

UNCTAD, Global trade impact of the coronavirus (COVID -19) epidemic ,op.cit ,P. 5 . انظر: 
معالجة الظروف الثاقة بموجب مبادئ اليونيدروا تتجاوز بكثير الإعفاءات البسيطة التي تتاولتها التشريعات الوطنية بشأن القوة القاهرة(60).

فإذا كان هذا هو موقف الاتفاقيات الدولية المتعقة بالتجارة الدولية فإن لطرفي العقود التي يحكمها القانون الدصري الاعتماد علي المادة (165) من القانون المدني المصري كسند قانوني لتوافرأو لاتتفاء المسئولية عن عدم تنفيذها لانتشار فيرس كورونا باعتباره سبب أجنبي ووضعت أمثلة له كالحادث مفاجئ أو القوة القاهرة وأي فعل يخرج عن إرادته ودخل في إرادة الغير أو المضرور ذاته وهو ما يمكن معه القول بأن القانون المصري أخذ موقفا مشابها لموقف اتفاقية الأمم المتحدة بشأن البضائع،إذ سهح بإدخال كافة التصرفات التي تعد مانع أمام التنفيذ غير إنهما اختلفا في الألفاظ فالاتفاقية اعتمدت علي لفظ عام "عائق" بينما القانون المصري اعتمد علي مجموعة كلمات مرنة تسمح بادخال العديد من الأفعال في إطار انتفاء المسئولية ، ووهو ما يظهر بوضوح من نصها علي :" إذا أثبت الثخص أن الضرر قد نشأ عن سبب أجنبي لا يد لله فيه ، كحادث مفاجئ أو قوة قاهرة أو خطأ من المضرور أو خطأ من الغير ، كان غير ملزم بتعويض هذا الضرر ما لم يوجد نص أو اتفاق على غير ذلك"،وهو ما تؤكد عليه نص المادة (373 )حينما نصت علي “ينقضى الالتزام إذا أثبت المدين أن الوفاء به أصبح مستحيلاً عليه لسبب أجنبى لا يد له فيه" ولم يكتفي المشرع المصري عند هذا الحد بل استثني من التعويض لعدم الوفاء بالالتزامات المدين الذي يقيم الدليل علي أن عدم التزامه يرجع لسبب أجنبي ولم يتعدد احداث هذا الخلل بل يرجع إلي سبب أجنبي خارج عن ارادته (61) وهو ما ينطبق علي فيرس كورونا وهو ما يظهر بوضوح من نص المادتين (165، 215 ) ، إذ نصت المادة( 215 ) من القانون المدني المصري سالف الذكر علي " “إذا استحال على المدين أن ينفذ الالتزام عينا حكم عليه بالتعويض لعدم الوفاء بالتزامه ما لم يثبت أن استحالة التنفيذ قد نشأت عن سبب أجنبي لا يد له فيه." لذا يجب قراءة المادتين (373،215)

60- إذ توفر المبادئ بالإضافة إلي الإعفاء- فإنها تصبغة بالصفة المؤقتة ـعلي أن يلتزم المدين بتقديم المعلومات الكافية عن الحدث ، وإلا جاز فرض

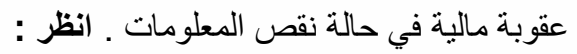

Guillaumond (R) , La gestion des difficultés d'exécution résultant de force majeure ou d'imprévision , op.cit , P.34

\section{https://www.adamas-lawfirm.com/upload/pdf/publications/707c59312ad17da1ac2b01e.pdf}

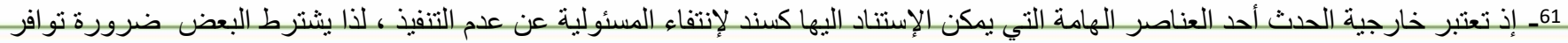

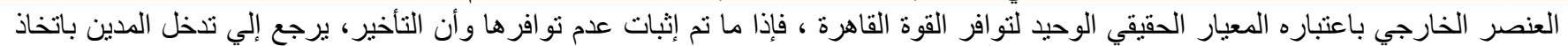

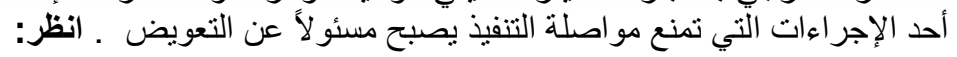

Carbonnier (J) , Les obligations, droit civil , Tome IV, PUE, Themis , 1994 ,no162 , p.271. 


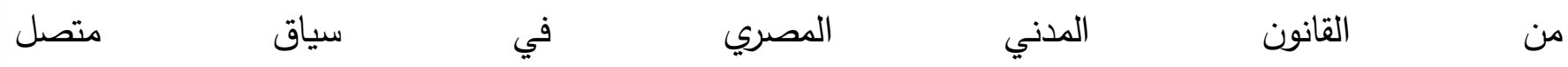
، وهو ما أكدت عليه المحكمة الإدارية العليا المصرية بأحد أحكامها (62) ، حينما قررت :" وأنه يحق للإدارة أن توقع الغرامة المنصوص عليها في العقد من تلقاء ذاتها وبمجرد وقوع المخالفة التي تقررت الغرامة جزاء لها ولا يتوقف استحقاق الغرامة علي ثبوت وقوع ضرر للادارة من جراء اخلال هذا المتعاقد بالتزامه وأنه لا يعفي منها إلا إذا اثبت أن إخلاله بالتزامه يرجع الي قوة قاهرة إلي خلل جهة الادارة المتعاقد معها" علي ألا يتذرع أحد الأطراف بوجود علاقة عقدية بينهم كسند لاستثاء القوة القاهرة من وذلك وفقاً للمادتين (147 ، 616 ) من القانون المدني المصري(63)هوهو ما أكدت عليه محكمة النقض المصري بأحد الحكام الصادرة عنها(64) حينماقررت " وكان مؤدي نص المادة 147 من القانون المدني في فقرتها الثانية - وعلي ماجري به قضاء هذه المحكمة - أنه إذا طرأت حوادث استثنائية عامة لم يكن في الوسع توقعها وترتب علي حدوثها أن تنفيذ الالتزام التعاقدي وإن لم يصبح مستحيلا سار مرهقا للمدين(65) ، بحيث يهدده بخسارة فادحة جاز للقاضي تبعا للظروف وبعد الموازنة بين مصلحة الطرفين أن يرد الالتزام المرهق إلي الحد المعقول ويقع باطلا كل اتفاق يخالف ذلك ... " ، وكذا ما أكده أحد الأحكام الصادرة عن محكمة النقض المصرية (66) حينما قررت :" إذا أثبت الشخص أن الضرر قد نشأ عن سبب أجنبي لا يد له فيه ، كحادث مفاجئ أو قووة قاهرة أو خطأ المضرور أو خطأ الغير ، كان غير ملزم بتعويض هذا الضرر ما لم يوجد نص خاص اتفاق علي ذلك ." . وهو ما لم يختلف عنه موقف القانون المدني الفرنسي بشأن معالجة القوة القاهرة التي يمكن لطرفي العقود التي يحكمها القانون الفرنسي الرجوع اليه لدفع المسئولية التي قد تقع علي عاتقهم نتيجة تخلفهم عن تنفيذ العقود اومواصلة تتفيذها والذي وضع تعريفا لها يمكن الارتكان إاليه لاستخلاص شروط تحققها ، وهو ما يظهر بوضوح من نص المادة 1218

62- انظر : حكم الدحكمة الادارية العليار رقم 2551 لسنة 31 ـ 3140

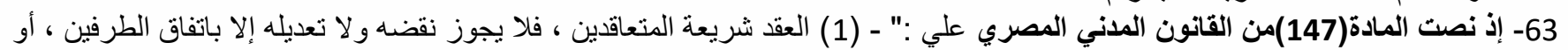

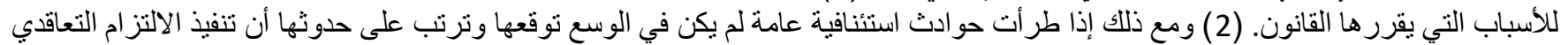

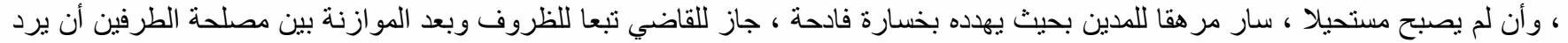

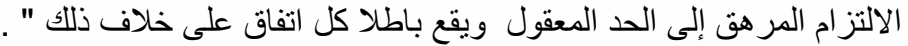

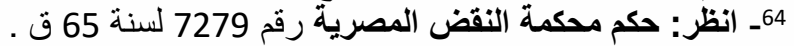

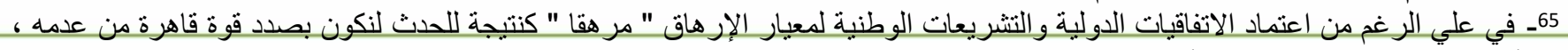

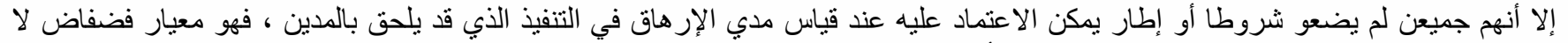

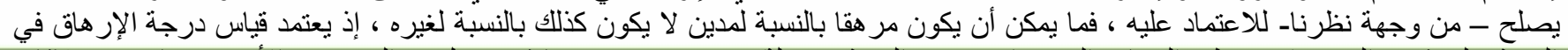

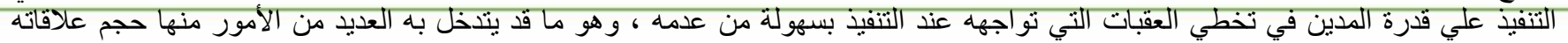

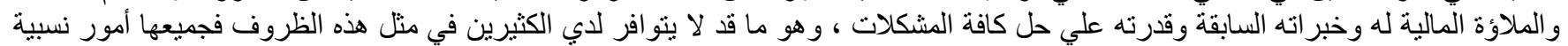

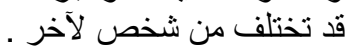
66ـ انظر : حكم محكمة النقض رقم 14696 لسنة 83 ق . 
من القانون المدني الفرنسي(67) حينما نصت علي أن القوة القاهرة حدث يخرج عن سيطرة المدين لم يكن من المعقول توقعه بتاريخ إبرام العقد و لا يمكن تجنب آثارة ويكون من شأنه أن يمنع المدين من تتفيذ موجبه ، وبالتالي فإن القوة القاهرة في الامور التعاقدية تتحقق حال توافر شرطين في الحدث هما: حتمية آثار الحدث واستحالة التتفيذ(68)، وهو ما يتحقق حينما يكون الحدث خارج عن سيطرة المدين والذي لا يمكن توقعه بشكل معقول عند إبرام العقد وأن يخرج عن السيطرة كما يجب أن يكون خطيرا بما لا يمكن تجنب آثاره رغم اتخاذ التدابير المناسبةوهو ما ينطبق علي فيرس كورنا المستجد(69) الذي نتج عنه حصاد الملايين من الوفيات خاصة مع ما يمتلكه الفيرس من قدرة فائقة علي الانتشار السريع وسرعة وصوله إلي الملايين حول العالم وما عضدد ذلك هوعدم توصل العالم إلي دواء ناجع بما يساعد الدول علي وقف زحفه وحصاده للأرواح ، ولعل ذلك هو ما دفع مجلس الدولة المصري إلي اعتبار فيرس كورونا قوة قاهرة في أحد أحكامه الصادرة حديثا - ويعد اول حكم قضائي مصري يعتبر فيرس كورونا قوة قاهرة في ظل انتشاره - ، إذ جاء به ": اجتاحت العالم حالة من القوة القاهرة دعت منظمة الصحة العالمية إلى اعتبار فيروس كورونا المستجد جائحة .... ، الحياة الإنسانية هي أغلي ما يمكن للحكومات والدول والمؤسسات الدحافظة عليها فحفظ النفس يعد أول

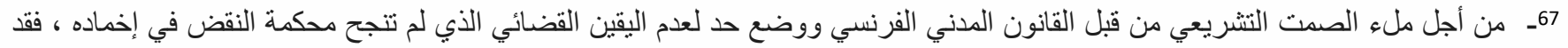

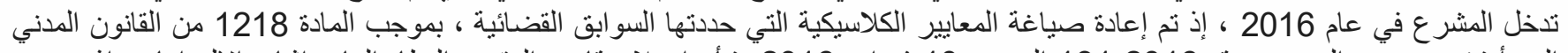

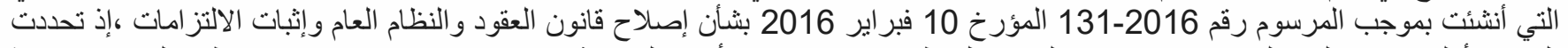

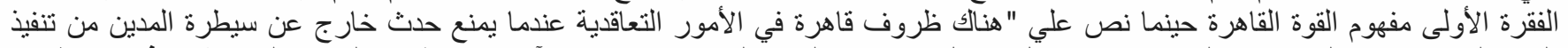

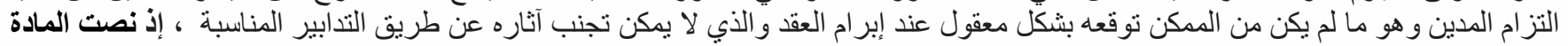

1218 من القانون المدني الفرنسي علي :

"Il y a force majeure en matière contractuelle lorsqu'un événement échappant au contrôle du débiteur, qui ne pouvait être raisonnablement prévu lors de la conclusion du contrat et dont les effets ne peuvent être évités par des mesures appropriées, empêche l'exécution de son obligation par le débiteur.

Si l'empêchement est temporaire, l'exécution de l'obligation est suspendue à moins que le retard qui en résulterait ne justifie la résolution du contrat. Si l'empêchement est définitif, le contrat est résolu de plein droit et les parties sont libérées de leurs obligations dans les conditions prévues aux articles $\underline{1351}$ et $\underline{1351-1 .}$.

Bamdé (A),La responsabilité contractuelle: régime juridique, op.cit.

Mathias Avocats, Covid-19 : un cas de force majeure ?, 20 mar2020

https://www.avocats-mathias.com/actualites/force-majeure-impacts-contrat

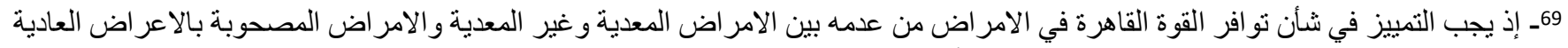
و غبر العادية (الجسيمة) لكي يكون خارج عن السيطرة وأن يكون المرض الذي يؤئر الأر على المدين خطيرًا بما فيه الكفاية وبالاضافة الي اعتبارة عائقا

Gastebled (É), Le clair-obscur de la force majeure en matière contractuelle face au Covid-19, op.cit . 
مقاصد الثريعة الإسلامية وسابقا علي حفظ الدين وبغير حياة الانسان لا تقوم الدنيا ومن أحيا نفسا كانما أحيا الناس جميعا " (10)

علي أن الآثار الناجمة عن تحقق العائق تختلف حسب ما إذا كان العائق مؤقتا يتم تعليق تتفيذ الالتزام ما لم يبرر التأخير إنهاء العقد ، واذا كان العائق نهائيا يتم إنهاء العقد تلقائيا ويتم تحرير الأطراف من الالتزامات وفقا للشروط المنصوص عليها في المادتين 1351، 1- 1351 من القانون سالف الذكر ، لذا يكون علي الأطراف في ظل انتشار فيرس كورونا إعادة قراءة العقود للوقوف علي مدي إدراج بند يتعلق بالقوة القاهرة من عدمه ، فوجود مثل هذا البند يعني الكثير بالنسبة لطرفي العقد ، فأما التزام بتنفيذ العقد رغم وجود القوة القاهرة و يتحمل تبعات ذلك وهي نادرة الحدوث في الواقع العملي فالأصل أن أحكام القوة القاهرة تتطبق ما لم يتفق الطرفين علي تحمل المدين تبعة القوة القاهرة (11)، وأما انتفاء المسئولية عن تتفيذ العقد خلال فترة انتشاره(72 يذكر أن المادة (165) من القانون المدني المصري والمادة 1148 من القانون المدني الفرنسي سالف الذكر (73) قد ساوتا بين القوة القاهرة والحادث المفاجئ وجعلت منهما فكرة واحدة تندرج ضمن نظام قانوني واحد (74)، ورغم تعدد التشريعات الوطنية التي يمكن الارتكان إليها كسند لإدراج فيرس كورونا ضمن أحداث القوة القاهرة التي يمكن الاعتماد عليها لدفع المسئولية الناجمة عن عدم تنفيذ العقود إلا أن هناك من التشريعات ما غضة الطرف عن القوة القاهرة - لفظا وموضوعً- كأحد الأسباب التي يمكن أن تكون سندا لانتفاء المسئولية فهو مبدأ غير معترف به من قبل القانون الانجليزي ، فبموجبه لا يمكن لطرفي العقد الذي يحكمه

70ـ انظر : الحكم الصادر من مجلس الدولة الدصري ، محكمة القضاء الاداري بالقاهرة ،في الدعوب رقم 37214 لسنة 74 ، الدائرة الثانية ، بتاريخ 28 يونيو 2020 71 انظر :دار شريف محمدغنام ، أثر تغير الظروف علي عقود التجارة الدولية ، المرجع السابق ، ص 20. : انظر

Berg-Moussa (M) , Le Coronavirus est-il un cas de force majeure et/ou une cause d'imprévision ?, op.cit.

73ـ اذ نصت المادة المادة 1148 من القانون المدني الفرنسي علي :" "Créé par Loi 1804-02-07 promulguée le 17 février 1804"

"Il n'y a lieu à aucuns dommages et intérêts lorsque, par suite d'une force majeure ou d'un cas fortuit, le débiteur a été empêché de donner ou de faire ce à quoi il était obligé, ou a fait ce qui lui était interdit

74ـ إذ إتفق الفقه علي عدم التمييز بينهم واستقر القضاء علي عدم التمييز بينهم تاسيسا علي أن القوة القاهرة يبرز بها خاصية استحالة التنفيذ ، أما

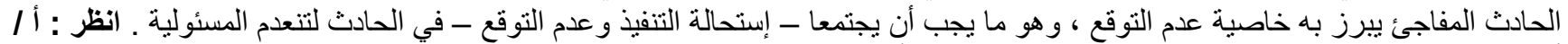

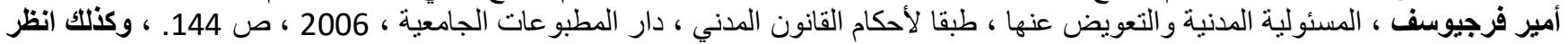

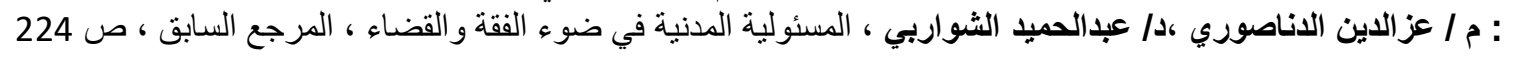


القانون الاتجليزي الاعتماد علي القوة القاهرة لدفع المسئولية ما لم يتم الإشارة إليها بصورة خاصة كذكر كلمة " الاوبئة " صراحة في العقد.

ولإثبات توافر القوة القاهرة في فيرس كورونا فقد وضعت بعض الدولة نظاما لذلك من خلال شهادة تمنح للشركات أو

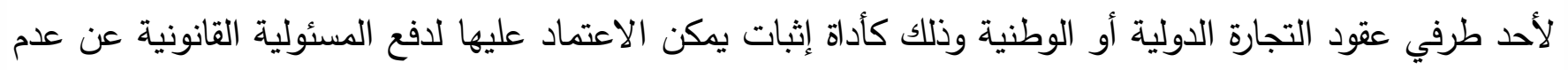
التتفيذ خلال فترة انتثار الفيرس في الدولة المعنية وبالتالي عدم تحمل التعويض عن عدم التتفيذ أو أي أضرار قد تلتتج الته

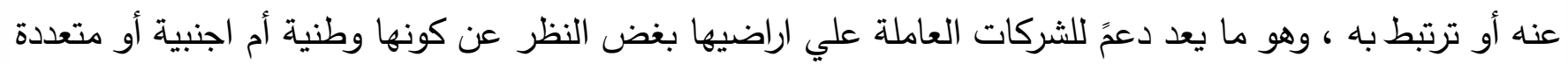

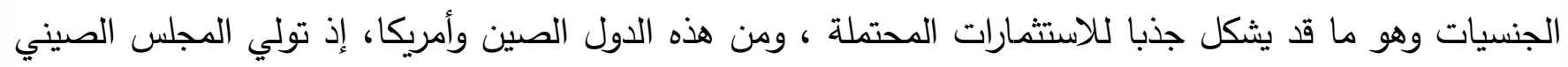

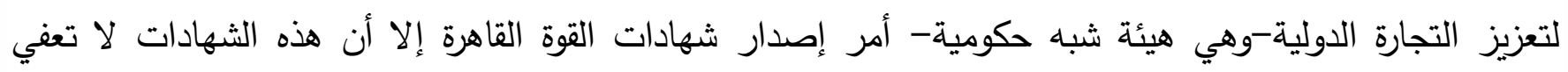

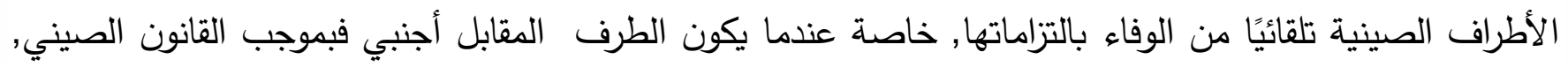

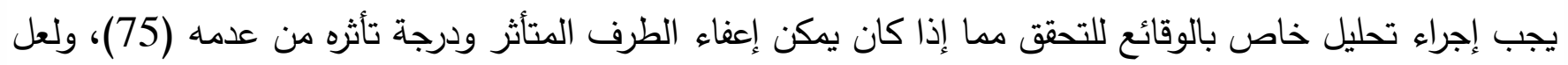

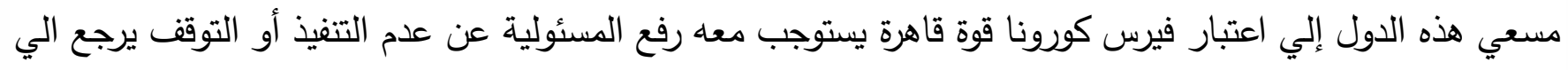
رغبة الدول في رفع المسئولية عن كاهل شركاتها والتحلل من التزاماتهم قبل الاطراف الاخري ، ولعل ذلك هو المهات المبرد

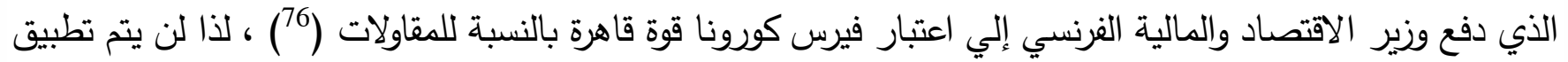
غرامات التأخير في التنفيذ علي الثركات المرتبطة بعقود مع الدولة ، مع منح المقاولين المتضررين مهلة إضافية حال ثبوت تضررهم جراء انتشار الفيرس(77) ، اما فيما عدا ذلك من عقود فإن توافر القوة القاهرة من عدمه يخضع لرأي لئي

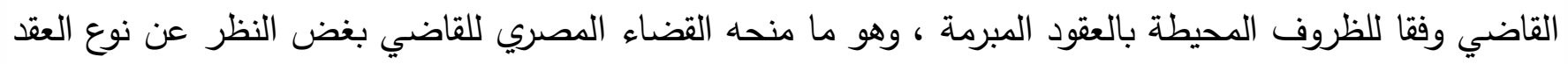

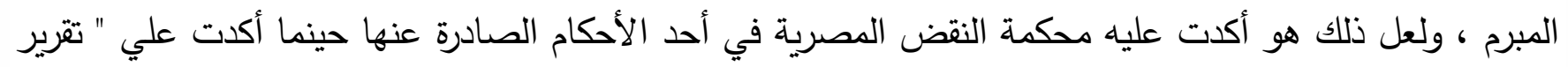
ما إذا كانت الواقعة المدعى بها تعتبر قوة قاهرة هو تقدير موضوعى تملكه محكمة الموضوع في حدود سلطتها التقديرية

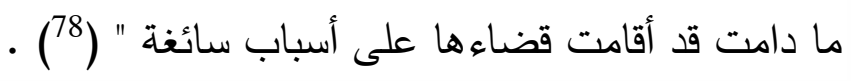

ويثار التسأول حول كفيفة تحديد الاماكن الموبؤه ، فعلي الرغم من إعلان منظمة الصحة العالمية اعتبار فيرس كورونا طوارئ صحية عالمية ووصفة انتشارة بالجائحة إلا أن هناك دول لم تتعرض له أو كان سرعة انتشار الوباء بها بطئ

International Arbitration, COVID-19, Force Majeure and Arbitration ,19/03/2020 . https://www.international-arbitration-attorney.com/ar/covid-19-force-majeure-and-arbitration/ 76ــ إذ أعلن وزير الاقتصاد و المالية الفرنسي ان وباء فيرس كورونا يمثل قوة قاهرة بالنسبة للشركات و الموظفين و أصحاب العمل و عقود

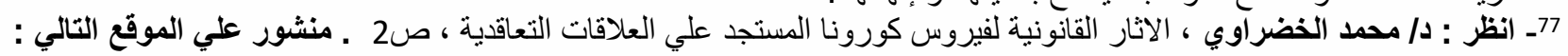
file://D:/\%D8\%A7\%D8\%A8\%D8\%AD\%D8\%A7\%D8\%AB\%D9\%8A/\%D8\%9\%8A\%D8\%A9.pdf

78 انظر : الطعن رقم 0026 لسنة 23 مكتب فنى 07 صفحة رقم 1022بتاريخ 27-12-1956" 
للغاية ، وهو ما يمكن أن ينطبق على الدول التي ترتبط بتنفيذ أحد عقود التجارة الدولية ، وهنا يمكن القول بعدم إمكانية الارتكان من قبل أحد طرفي العقد إلى القوة القاهرة كسند لانتفاء المسئولية عن عدم التتفيذ لأن السبب وراء الإعفاء من المسئولية قد انتفي فبإمكانه تنفيذ العقد دون استحالة في التتفيذ، وهو ما يدفعنا إلي التسأول بشأن هذا النوع من العقود التي ترتبط بعقود أخري يتم تتفيذها في نطاق إحدى الدول التي تم الإعلان بثأن اعتبارها منطقة موبؤة بفيرس كورنا ، فهنا هل يمكن أن يستيد بتحقق القوة القاهرة حال الاعتماد الأساسي علي هذه الدولة كمورد رئيسي للمواد الاساسية الضرورية لتتفيذ العقد كما لو تم التعاقد بين طرفين علي أن يتم تنفيذ العقد في السلفادور أحد دول امريكا اللاتينية التي لم ينتشر بها الوباء لكن يرتبط أحد طرفي العقد لتنفيذه بعقد آخر مع أحد موردي الشرائح الإكترونية بمدينة ووهان الصينية - وهي بؤرة تفشي فيرس كورونا بالعالم - وبالتالي يستحيل تتفيذ العقد اعتماد علي القوة القاهرة فهل يستفيد أحد طرفي العقد من ذلك كسند لاستحالة التنفيذ وبالتالي الإعفاء من المسئولية ، ونري في هذا الثأن أنه لا يملك الحق في التمسك بتحقق القوة القاهرة بالنسبة لتتفيذ العقد ، وبالتالي الإعفاء من المسئولية عن عدم التتفيذ بسبب انتشار الفيرس لأنه لا علاقة للطرف الآخر في التعاقد بالعقد المبرم بينه وبين أحد موردي الشرائح الإكترونية بمدينة ووهان ، إذ يلتزم بأداء التزاماته التي تتاولتها بنود العقد بغض النظر عن العقود التي ترتبط بهذا التنفيذ . المطلب الثاني

\section{عدم إمكانية التنبؤ بتعرض العالم لفيرس كورونا وقت توقيع عقود التجارة الدولية}

لعل عدم التتبؤ أو التوقع بحدوث وباء ما هو ما يسجله التاريخ عن الاوبئة والأمراض المميته التي عصفت فيما مضي بالعالم ، فالكوليرا مثلاً لم يكن يتوقعها أحد وكذا السارس، وهو ما انطبق علي فيرس كورونا الذي ضرب العالم خلا الأشهر الأخيرة من عام2019 واستمر للأشهر الاولي من 2020 ويتوقع العلماء استمراره لأعوام قادمة ، فلم يكن العالم يدرك حجم الكارثة التي تعرضت لها احد المدن الصينية ( ووهان) والتي اصبحت فيما بعد مركز الوباء العالمي لدرجة اصبح معها جائحة ، إلي أن تسلل المرض رويدا رويدا إلي العالم متخفيا في جنح الظلام ليسطع فجر يوم جديد علي العالم يغير به واقعهم إلي واقع أليم ليعلن الفيرس سيطرته علي العالم في حرب لا تعرف العده والعتاد ، وهو ما منح لاطراف العقود التجارية المبرمة حول العالم الحق في الحصول علي فرص التوقف عن الدفع أو الوفاء بالالتزامات نظرا لما خلفه هذا الفيرس من ارتباك في الحياة التجارية والاقتصادية. 


\section{منى عمار}

ولعل هذا الارتباك هو المبرر الذي دفع المشرع الدولي إلي البحث منذ زمن بعيد عن حل لمساعدةالمتعاقدين لتخطي ما يواجههم من عثراتلم تتدخل ارادتهم لاحداثها والتي تختلف حسب الظروف المحيطة من وقت لآخر ، إذ تتاولتها الفقرة (أ ،ب) من المادة 6-2-2 من مبادئ اليونيدروا حينما نصت علي :" تتوافر الظروف الثاقة إذا وقعت أحداث

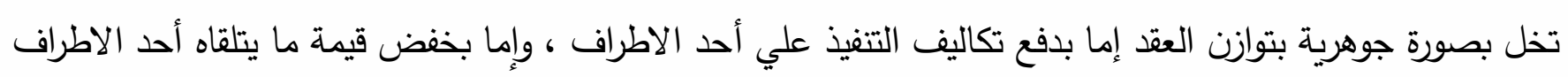
، ويتعين توافر ما يلي : (2)

أ ) أن تقع هذه الأحداث، أو يعلم بها الطرف الذي تعرض لها، بعد إبرام العقد

ب) أن لا يمكن أخذ هذه الأحداث في الحسبان بصورة معقولة من قبل الطرف الذي تعرض لها، عند إبرام العقد " ولعل ذلك مرجعة ان الطرفين اذا كان بمقدورهم التنبؤ بوقوع فيرس كورونا باعتباره الحدث غير المتوقع لكان باستطاعتهم طرح كافة التسأولات والحلول أثناء المفاوضات التي تمكنهم من التباحث بشأنه ، للوقوف علي الحل المناسب للطرفين لمواجهته دون الإخلاد بالتوازن العقدي الذي من أجله تدخل المشرع لمعالجة ما يعتريه من خلل عند حدوث قوة قاهرة - والتي قد تتمثل في انتشار فيرس كورونا- لإعادته الي طبيعته في الأوقات العادية ، وهو ما ينطبق علي الحدث المتوقع حدوثة في المستقبل بعد إبرام العقد وأثناء نفاذه .

وبالتالي فإن أي حدث يقع في الفترة السابقة علي إبرام العقد أو التالية لانتهائه - وفقا للمجري العادي بالنسبة لتحقق القوة القاهرة من عدمه - لا تخضع لبنوده فالفترة التي يسأل عنها هي الفترة التالية لإبرامه والسابقة علي انتهائه ،

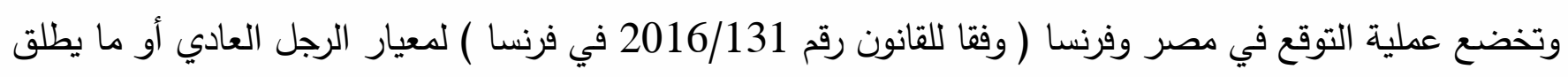
عليه رجل الصناعة الذي يمكنه أن يتوقع حدوثة وفقا لما يتمتع به من مهارة ، وإن كان أستاذنا العلامة عبدالرازق السنهوري باشا قد استوجب أن يكون الحادث غير مستطاع التوقع لا من جانب الددعي فحسب بل من جانب أشد الناس يقظة وتبصرا بالامور (79)وهو ما نتقق مع سادته فيه إلا أن هذا الأمر يمكن قبوله فيما مضي حينما كان العالم يفتقر إلي التكنولوجيا والدراسات الدقيقة التي تمنح المتخصصين فرصة دراسة العديد من الأمور المستقبلية وخاصة فيما يتعرض ببعض الأمراض والفيروسات ، ففي عصر سادة فيه التكنولوجيا وتسارعت وتيرة حداثتها لارجة تجعل الكثير من الأمراض والفيروسات محل توقع لا يمكن قبول هذا الأمر علي إطلاقه فإن كان كافة الفيروسات والأمراض ليست

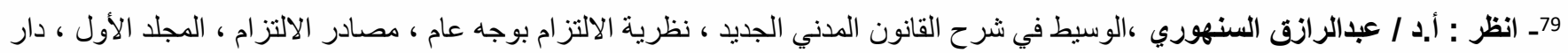

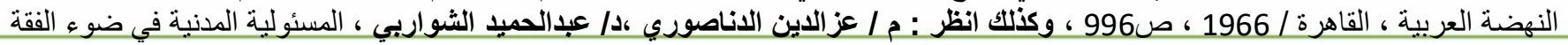
و القضاء ، المرجع السابق ، صـ الفرة 231 . 


\section{منى عمار}

محل دراسة ، إلا أن معظمها تحت الملاحظة من قبل العلماء والمتخصصين وهو ما قد يطلع عليه غيرهم من غير المتخصصين ، وبالتالي بما يمكن معه القول بأنه أصبح جزء كبير منها مستطاع التوقع •

علي أن فيرس كورونا وهو أحد الامراض المعدية باعتبارةه عائق صحي قد يثور التسال بشأن قدرة رجل التجارة علي التتبؤ به أو التعرف علي إمكانية حدوثه فهو من وجهة نظرنا لا يمكن القول بقدرة الرجل العادي علي التوقع بحدوثه عند ابرام العقد ، فهو أحد الامور التي تحتاج إلي متخصص وهو ما قد ينتفي في بعض عقود التجارة الدولية ،وهو ما لا يمكن أن يؤخذ علي إطلاقه فقد يصل العلم إلي أحد طرفي عقود التجارة الدولية بأن تتناقل وسائل الإعلام من خلال المناقثات والحوارات الإعلاميةالتي ثُدار بين المتخصصين بشأن توقعاتهم حول احتمالية تعرض العالم لفيرس انتشار خلال فترة معينة هنا يكون قد أصبح العلم باحتمالية حدوثه متناقلة بين العامة و كان بمقدورة أن يعلم باحتمالية حدوثه مستقبلا فهنا نكون بصدد معلومة مؤكدة يجب أن تكون محل نقاش أثثاء إجراء المفاوضات ضمن بنود العقد المزمع إبرامه ، أما إذا كانت هذه المعلومات لا يعلم بها سوي شرزمة قليلة من المختصين بالثأن الصحي فلا مجال للبحث عن إمكانية علمه أو توقعه ، وبالتالي يكون من حق الطرف الذي تعرض لها الاستفادة من توافر شروط القوة القاهرة ، ليصبح غير مسئولا عن التعويض ، علي أن استعمال المبادئ لعبارة " بصورة معقولة " تهدف الي الوقوف علي مدي قدرة الطرف المعني علي تفادي تأثير انتشار فيرس كورونا علي تتفيذ العقد قبل حدوثه أو علي الأقل تجنب آثار انتشارة بعد إبرام العقد ، وذلك وفقا للسلوك العقلاني(80)، وهو ما يعني نسبية التنبؤ بمعنى أنه لا يجب لاعتبار الحدث قوة قاهرة غير متوقع على إطلاقة (18) .

وهو ما كان محلاً للمعالجة من قبل اتفاقية الأمم المتحدة بشأن البيع الدولي للبضائع اتفاقية فيينا 1980 ، إذ لم تغفل شرط عدم توقع(82) حدوث فيرس كورونا وتحوله إلي وباء عالمي و لم تكن منه ببعيد حيث تتاولته المادة (79) من الاتفاقية سالفة الذكر ، وجعلت منه شرطا لاتتفاء المسئولية لانه لو كان متوقعا لكان بالامكان تفادية عند اجراء المفاوضات حينما نصت علي :" ... وأنه لم يكن من المتوقع بصورة معقولة أن يأخذ العائق في الاعتبار وقت انعقاد العقد أو أن يكون بإمكانة تجنبه أو تجنب عواقبة أو التغلب عليه أو علي عواقبة "، علي أن الاتفاقية قد افترضت حسن

80ـ انظر :د/ هني عبداللطيف ، حدود الاخذ بفكرة إعادة التفاوض في العقد " دراسة مقارنة" ، جامعة أبي بكر بلقايد ، الجزائر ، رسالة دكتوراه ، 2016/2015، صن : 89 : انظ

Bamdé (A),La responsabilité contractuelle: régime juridique, op.cit . 82. انظر : أ / أمير فرجيوسف ، المسئولية المدنية والتعويض عنها ، المرجع السابق ، ص 144. 
النية لدي الطرف المعني - وهو مبدأ يسود التجارة والمتعاملين فيها - والذي تمكن من التوقع أو الاطلاع علي معلومات سرية تثير إلي أنه من المتوقع أن يتعرض العالم لفيرس كورونا خلال الفترة السابقة علي إبرام العقد دون أن يطلع الطرف الآخر عليها وكان هذا هو الدافع والمحرك الاساسي لابرام العقد فانه في هذه الحالة يكون من غير المنصف أن يترك هذا الطرف لينعم بسوء نيته ويجني ثمارها ، وبالتالي فإن من حق الطرف الآخر الذي يقيم الدليل علي ذلك أن يلزمه بالتنفيذ أو إعادة التفاوض بشأن بنود العقد ليكون سبل تفادي أثارهذا الفيرس محلا لنقاش. علي أنه لا يوجد معيار يمكن من خلاله الوقوف علي الفترة الزمنية التي يجب أن يحدث التنبؤ بحدوث كارثة فيرس كورونا خلالها، وهو ما يصبح معه الفترة الزمنية مفتوحة فيستوي أن يكون قبل انتشار الفيرس بسنوات أو أشهر أو أيام ، المهم هو العلم أو التنبؤ المسبق علي حدوثه ، وهو ما يمكن معه القول بانطباقه علي العديد من العقود التي تم إبرامها قبل انتثار الفيرس بيوم واحد ، المهم هنا هو أن هؤلاء المتعاقدين كانوا قد تتبؤ بحدوثه من عدمه ، بالاضافة الي قدرته علي تجنب آثارة بإمكانية تجنبة أو تجنب عواقبة أو التغلب عليه أو علي عواقبة وهو ما يعني أين كان نوع التوقع بالحدث أو آثاره أو نتائجه يصبح معه الطرف الآخر مسئول عن تقصيرة من عدمه ، فالحدث في حد ذاته لا يشكل في جوهرة قوة قاهرة ، وبالتالي يتم دراسة كل حالة تعاقدية علي حده ( 183 . كما تتاولت شرط إمكانية التنبؤ أو توقع حدوث فيرس كورونا باعتباره عائق ، الثروط النموذجية بشأن إعادة التفاوض التي تم وضعها بمعرفة غرفة التجارة العالمية ، حينما أكدت علي أنه في حالة وقوع أحداث غير متوقعة من قبل الأطراف من شأنها أن تعدل بشكل أساسي التوازن العقدى ،إذ يتم استكمال ما يتعلق بالحادث في الثروط النموذجية، وهو ما يفهم منه أن الاستعانة بالتتبؤ أو التوقع يجد أهميته فيما يمنحه للعقد من مساعدة طرفاه في الإبقاء علي التوازن العقدي الذي يساعده علي البقاء دون عوائق في التتفيذ و إلا فإنه يكون من حق أحد الطرفين عند حدوث خلالاً ما في التوازن العقدي- بشكل يصبح معه تتفيذ العقد مرهقا له ولم يوافق علي تحمل مخاطرة أن يتدخل لإعادة هذا التوازن ، كما لو كان من شأن اتخاذ التدابير الاحترازية من تعقيم وتطهير لمواجهة المرض واستكمال تتفيذ العقد مرهقا لدرجة كبير كما في عقود الإنشاء أو نقل التكنولوجيا ، فإذا كان بإمكان أحد الأطراف التتبؤ بحدوث فيرس كورونا الذي من شأنه أن يصبح معه التنفيذ مرهقا أو مستحيلا فإنه يكون ملزما بمقتضي مبدأ حسن النية بأن يطلع الأطراف علي 
توقعاته لتدارك اثاره عند حدوثة (84)، خاصة اذا كان من شأن هذا التوقع ان يعيد ترتيب العقد من جديد أو مساعدة الاطراف الاخرى علي اتخاذ قرار التوقف عن مواصلة المفاوضات بشأن العقد المزمع إبرامه إذا كان الدافع وراء إبرام هذا العقد هو الاستفادة ماديًّ من اعتباره قوة قاهرة.

مع الأخذ في الاعتبار أنه إذا كان عدم القدرة على التتبؤ خاضعًا لأحكام قانونية ،الا أنه يمكن للعقد تعديلها إذا تم إدراجه ضمن بنود العقد باعتباره بندا تعاقديً: ، إن وجد ، والذي يجب الإشارة إليه لتحديد ما إذا كان يمكن لأحد الأطراف التذرع بظروف غير متوقعة أم لا وما هي الآليات التعاقدية الموضوعة للتغلب على هذا التغيير الذي يواجه تنفيذ العقد ، والا سيكون من الضروري إجراء تحليل ملموس للوضع وأن يثبت الطرفان حسن النية في مناقشاتهما ، وذلك في الحالات التي يتم فيها ذكر عبارة " ظروف غير متوقعة " أما اذا لم تخطط الأطراف أو ترتب البند المتعلق بهذا الموضوع يكون للقاضي ، بناء على طلب أحد الطرفين ، صلاحية مراجعة أو إنهاء العقد ، بالثروط التي سيحددها (85) (15)

تجدر الإشارة إلي أن عدم التتبؤ بانتشار فيرس كورونا لا يرتبط ارتباطشرطي باستقلال الحدث عن إرادة اطرافه ، فقد

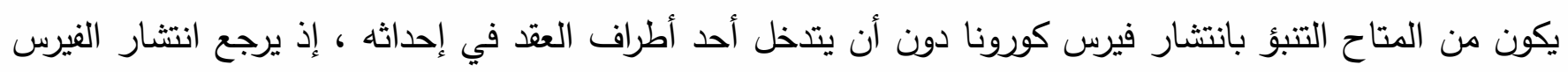
إلي انتقاله من الحيوان الإلي البشر - ومن هنا كانت البداية- وهو ما يعد حادث خارجً عن ارادة أحد طرفي العقد فلم يتدخل في احداث العدوي أو انتشارها، لكن قد تكون البداية مختلفة بأن يتدخل أحد اطراف العقد بنشر هذا الفيرس بين البشر مباشرة أو من الحيوان إلي البشر ليستقيد من هذا الانتشار بأن يستخدمه ذريعة لعدم الاستمرار في تتفيذ العقد أو لتعديلة ، وقد يتخطي الأمر حدود العقد لنكون بصدد خلق أزمة اقتصادية أو صحية . كما يرتبط استقلالية الحدث أو التنبؤ به بقدرة أحد الطرفين علي دفع هذا الفيرس باعتباره الحدث -لا مفر منه - وفي تجنب آثاره - لا يمكن التغلب عليه - فإذا كان بمقدوره أن يدفع أو يوقف زحفه أو يتخذ التدابير اللازمة لدفع انتشار هذا الفيرس وانحصاره في نطاق جغرافي معين بما لا يسمح بانتشاره وتفشيه ، بغض النظر عن تكلفة هذه التدابير والتي قد ترتفع لدرجة تفوق التكلفة المتوقعة لمواصلة التنفيذ وهو ما ينتج عنه عدم القدرة علي التتفيذ فلا مجال للحديث

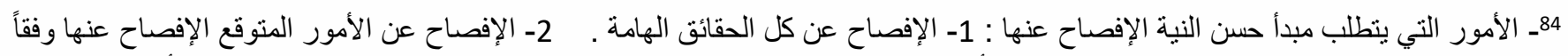

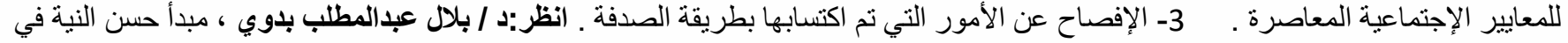

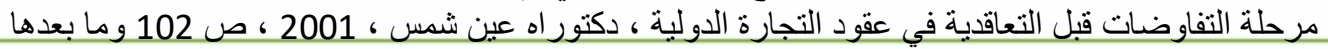

Berg-Moussa (M) , Le Coronavirus est-il un cas de force majeure et/ou une cause d'imprévision ?, op.cit . 
عن إعفاؤه من المسئولية عن عدم التنفيذ ، علي أن عدم القدرة علي دفع هذا الفيرس لم يتم تحديد معيارة (86) أو نطاقة، وبالتالي فإن عدم القدرة علي الدفع تقتصر علي النطاق الذي يساعده علي التتفيذ فقد يكون انتشار الفيرس قاصر في نطاق دولة معينة- كما في بداية انتشار المرض الذي بدأ من الصين - ولا تدخل هذه الدولة ضمن نطاق تتفيذ العقد ، في هذه الحالة لا توجد علاقة مباشرة بين انتشار الفيرس وعدم القدرة علي تتفيذ العقد باعتباره عائق يحول دون تمامه - وإن وجود علاقة غير مباشرة إذا كانت الصين هي مصدر المواد الأولية اللازمة لتصنيع المنتجات أو أداء الخدمات - ولا يقتصر علي ذلك فحسب بل يمتد ليشمل عدم القدرة علي تجنب آثار انتشار فيرس كورونا ("87) فلا لا يمكن التغلب عليه وحصره في نطاق معين وهو ما تحقق إذ كانت الصين هي بؤرة انتشار المرض وهي المصدر الرئيسي للمواد الأولية أو المنتجات موضوع العقد ، فهنا يكون الوباء قد انتشر لدرجة تحول دون السيطرة عليه ومنع مواصلة انتشاره وهو ما يشكل عائق يحول دون التنفيذ (88)، ولعل هذا هو ما يمكن فهمه من الفقرة (ج) من المادة (79) حينما نصت علي :"ج) أن تكون هذه الأحداث خارجة عن سيطرة الطرف الذي تعرض لها "غير أن القوانين الوطنية ومن بينها فرنسا قد اعتمدت بشكل كبير علي الاجتهاد القضائي في تقييم الطبيعة التي لا تقاوم للحدث ، كما ان القضاء الفرنسي لم يكن متساهل في ذلك وانما اتخذ من الصرامة منهجا عند تقييم الحدث ، وهو ما يمكن ان يشكل العقبة الرئيسية أمام الاعتراف بـ Covid-19 كقوة قاهرة(89) وذلك وفقا للسوابق القضائية ، إلا أنه أصبح لجائحة كورونا الفضل الكبير في دفع القضاء الفرنسي إلي الحيد عن موقفه المتشدد ليجعل من انتشاره قوة قاهرة ينتفي معها المسئولية ، وذلك وفقا لأحدث الأحكام الصادرة عن أحد المحاكم الفرنسية كالحكم الصادر من محكمة استئناف كولمار الفرنسية

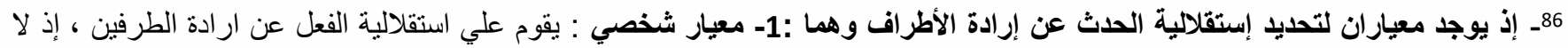

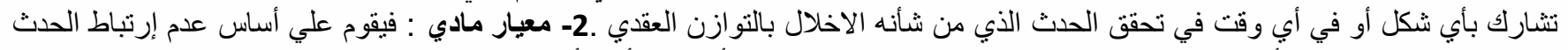

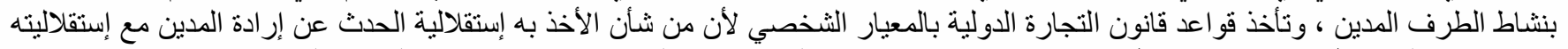

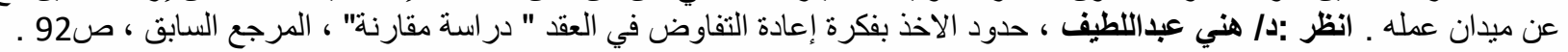
: انظر

Moury (J) , Force majeure : eloge de la sobriete , Revue trimestrielle de droit civil , Dalloz , paris 2004, p.471.

: انظر

H-P.Antomattei,contribution a letude de la force majeure, pref.B. teyssie, L.G.D.J, 1992,NO49

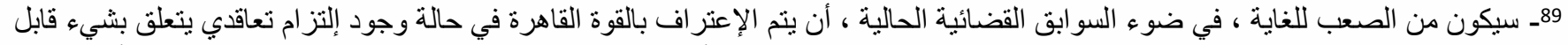

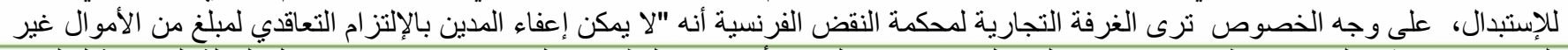

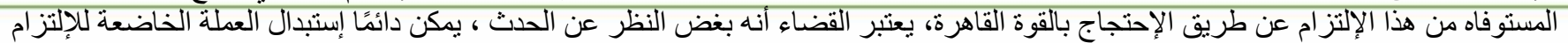

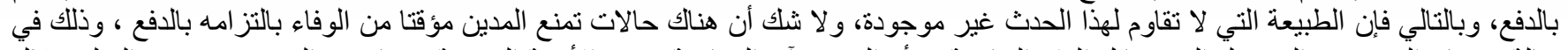

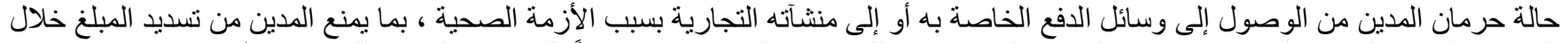

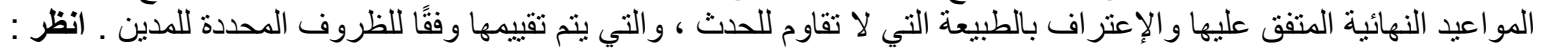

Gastebled (É), Le clair-obscur de la force majeure en matière contractuelle face au Covid-19 , op.cit . 
في 16 مارس 2020 (90) والذي اعتبر أن" الظروف المتعلقة بفيرس كورونا المستجد هي بحالة تطور مستمر وسرعة انتشار المرض والعدوي الناتجة عنه تشكل خطرا حقيقيا وجديا وكبيرا بالنسبة للأشخاص الذين يقومون بتسيير شؤون الجلسات في المحاكمة ، وأن هذه الظروف تتصف بالقوة القاهرة كونها خارجية غير متوقعة ولا يمكن دفعها " غير أنها كانت أكثر حرصا في ذلك حينما اشترطت علم اطراف العلاقة العقدية بالوباء وتاريخ ذلك العلم وهو ما نصت عليه المادة 1351 من القانون المدني الفرنسي • علي أن إدراج الثروط المتعلقة بالقوة القاهرة يتم ضمن بنود عقود التجارة الدولية دون النظر إلي القانون الواجب الطبيق ، إذ يتم في هذا الثأن الاعتماد علي العقود النموذجية التي تتولي بعض المنظمات الدولية المستقلة وضعها لتكون نماذج استرشادية لمساعدة الطرفين علي إبرام العقود الدولية والتي قد تمت علي نطاق واسع مما قد ينشأ عنها العديد من المشاكل التي قد تواجه الطرفين عند تتفذ العقد نتيجة الاستخدام التلقائي لهذه النماذج ، والتي لا تصلح في كل الحالات دون إجراء بعض التعديلات عليها ،فعند صياغة الشروط المتعلقة بالقوة القاهرة يجب الأخذ في الاعتبار أن كل عقد دولى يخضع في نهاية المطاف لقانون البلد المعني ، علي أن بند القوة القاهرة وبند المشقة يتفقان في الهدف الرئيسي بينهم في إنهما يسعيان الي تقليل الضرر الذي قد يلحق بأحد الطرفين لتغير ظروف العقد (191) مع الأخذ في الإعتبار أن شرط المشقة يندرج ضمن أنواع القوة القاهرة ، إذ يسمح بند المشقة - ما لم يوجد نص تعاقدي باستثناء تطبيقها وفقا للمادة 1195 من القانون المدني الفرنسي(92) والتي تاخذ بفرضية " تغير الظروف المتوقعة عند إبرام العقد " مما يؤدي إلى "أداء مفرطومكلف للطرف الذي لم يقبل تحمل المخاطر (93) -سمراجعة العقد عند وجود ظروف خارجية

Colmar,16 mars2020, n 20/01142, n 20/01143.

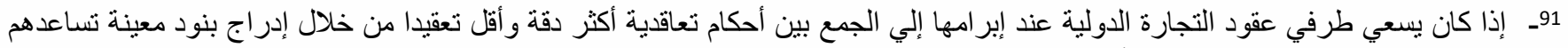

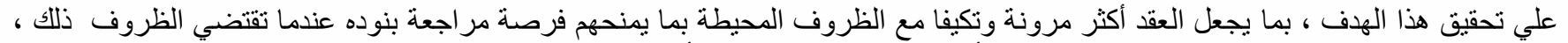

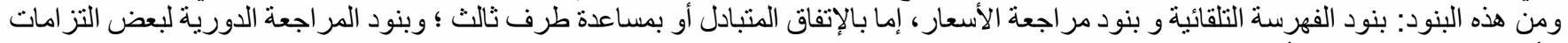

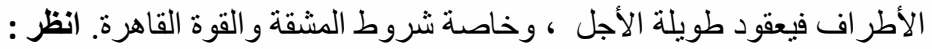
Guillaumond (R) , La gestion des difficultés d’exécution résultant de force majeure ou d'imprévision , op.cit , P.13.

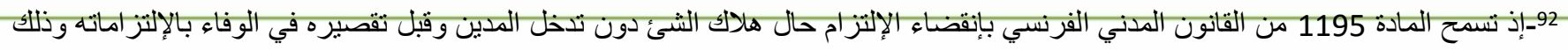

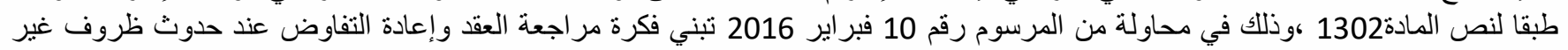

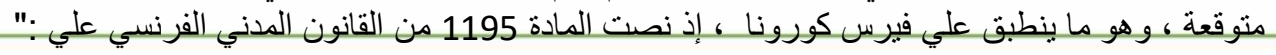
" Créé par Loi 1804-02-07 promulguée le 17 février 1804 "

"Si les deux choses sont péries sans la faute du débiteur, et avant qu'il soit en demeure, l'obligation est éteinte, conformément à l'article 1302. " 
- قد تكون اقتصادية أو تجارية أو صحية - كانتشار فيرس كورونا في نطاق دولة معينة بتعديل اقتصاد العقد ، وهو ما يسمح بإعادة التفاوض بموجب حسن النية بين الطرفين لإعادة التوازن العقدي إليه ، وبالتالي فإن مراجعة العقد المبرم من قبل أحد الأطراف قبل التوقف عن مواصلة تنفيذه لانتشار فيرس كورونا والذي اصبح مرهقا لدرجة أن أصبح تتفيذ العقد شاقا عليه قبل أن يصل إلي مرحلة الاستحالة في التنفيذ يصبح أمرا حتميًا ،وهنا يتضح لنا أهمية مراجعة العقد والتوقف علي ظروف العقد لتبيان حقيقة أمر انتشار فيرس كورونا واعتباره قوة القاهرة أم مشقة في التتفيذ(94) فعلي الرغم من اعتبار فيرس كورونا جائحة عالمية إلا أن درجة انتشاره وتاثيرة علي اقتصاد الدول- بغض النظر عن درجة تقدمها من عدمه - يختلف من دولة إلي أخري(95)، وهو ما ينسحب علي تتفيذ عقود التجارة الدولية. ونظرا لأهمية إدراج بند القوة القاهرة بالعقد واهميته الكبير وتأثيره المباشر علي التزامات الطرفين فإنه يجب صياغة هذا البند باحترافية عالية ودقة كافية بما لا يدع مجالا لإلغاءه أو يصبح عرضة للإبطال ، وهو ما يتحقق حال صياغته باستخدام كلمات غير دقيقة والفاظ فضفاضه ليسمح بدخول كافة الاحداث التي يمكن أن يتعرض لها التتفيذ بغض النظر عن اعتبارها قوة قاهرة من عدمه بما يفقد البند فاعليته وهو ما ينسحب علي العقد وذلك وفقا للمادة 1170 من القانون المدني الفرنسي(96) لذا يجب علي الأطراف إدراج مجموعة من الأحداث التي يمكن أن تشكل قوة قاهرة وفقا لخبراتهم السابقة في المجال ذاته أو في مجالات ذات صلة بالعقد بما يمنع عنها شبح الإبطال ، وهو ما قد يلحق بعقود الإذعان التي لا يملك أطرافه مناقشة بنودها لإخضاعها للتعديل مستعينا بمركزه المسيطر الذي يمنحه فرصة فرض

Gastebled (É), Le clair-obscur de la force majeure en matière contractuelle face au Covid-19, op.cit.

94ـ يتبلور الاختلاف بين القوة القاهرة والمشقة في مدي قدرة احد الاطراف علي تتفيذ العقد من عدمة فاذا رافق تتفيذه العقد مشقةمادية او اقتصادية

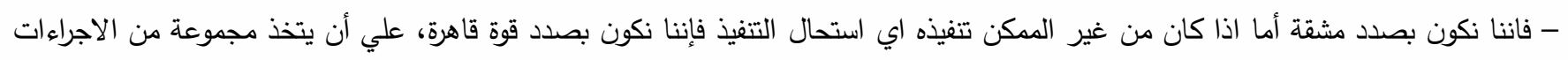
للاستفادة من اعتبار فيرس كورونا عائقً يحول تتفيذ عقود التجارة الدولية .

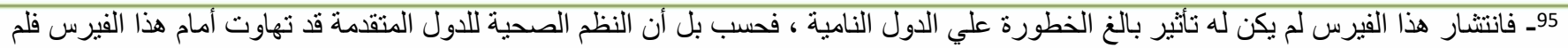

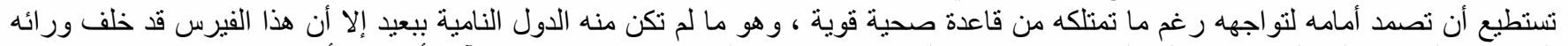

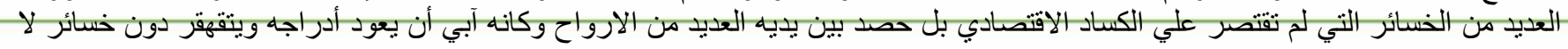

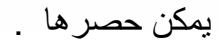
96- إذ نصت المادة 1170 من القانون المدني الفرنسي علي : “Toute clause qui prive de sa substance l'obligation essentielle du débiteur est réputée non écrite." 
العديد من الالتزامات علي عاتق الطرف الاخردون اعتراض من جانبه بما يؤدي الي اختلال التوازن العقدي لصالحه بطريقة تعسفيه((97)، وهو ما يمكن ان يفهم من نص المادة 1171من القانون المدني الفرنسي(98) .

ووفقا لذلك يجب أن ينشأ عن تحقق العائق غير المتوقع إخلال بالتوازن العقدي ، والذي يعد هو الجوهر و الأساس والفيصل في الاستفادة من الإعفاء من المسئولية المترتبة علي حدوث العائق من عدمه ، لذا يكون من غير المجدي البحث عن الإعفاء من المسئولية عن عدم التنفيذ في عقود التجارة الدولية حال تحقق العائق وشروطه دون أن ينتج آثاره من استحالة التنفيذ ، فقد تتحقق الشروط دون أن ينتج عنها إخلال بالتوازن العقدي(99)،وبالتالي يمكن الاعتماد علي التوازن العقدي كمعيار يمكن الارتكان إليه بعد البحث في توافر الشروط في العائق ، فإذا نتج عن العائق إخلالاً بالتوازن العقدي فإن للأطراف الخيار بين أمرين إما أن يلجأ إلي إعادة التفاوض ويكون هذا الإخلال محلاً للنقاش والبحث عن حلاً بما يعيد إلي العقد توازنه أو إعتباره مخالفة جوهرية يتم بموجبها إنهاء العقد ، بغض النظر عن درجة الاخلال الذي لحق بالتوازن العقدي فقد يكون بسيطا أو جسيمًا(100) .

المبحث الثاني

\section{أثر اعتبار فيرس كورونا عائقاً أمام تنفيذ عقود التجارة الدولية}

لعل انتشار الأوبئة والأمراض المعدية ليس بجديد علي العالم بل تعرض العالم خلال العقود القليلة الماضية لبعض الأوبئة والأمراض إلا أنها لم تكن بحجم فيرس كورونا ولم يتخلف عنها هذه الخسائر التي فاقت التوقعات سواء

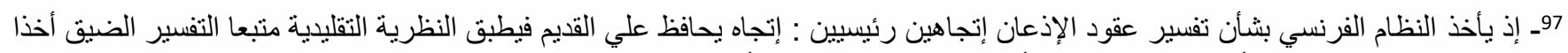

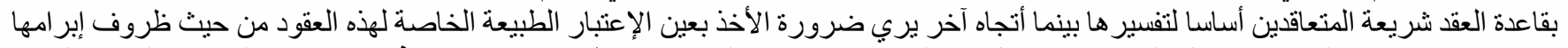

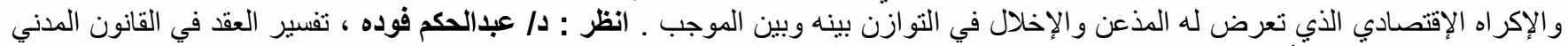

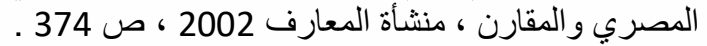

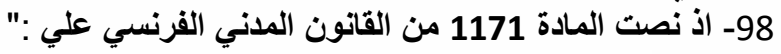

" dans un contrat d'adhésion, toute clause qui crée un déséquilibre significatif entre les droits et obligations des parties au contrat est réputée non écrite "

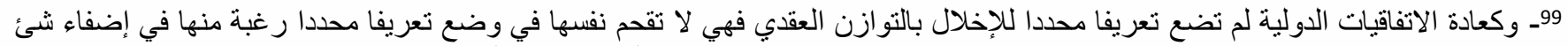

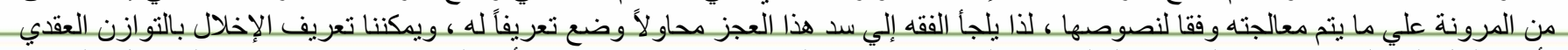

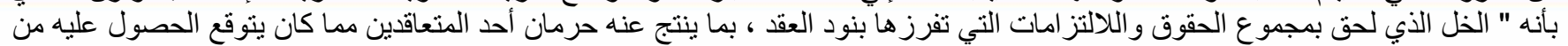

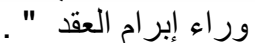
100ـ انظر : د/ هشام ضيف الله عبدالمالك الملهطالي ، التفاوض في عقود التجارة الدولية ، المرجع السابق ، ص 507 . 
الاقتصادية أو الصحية ، إذ لم تجول هذه الاوبئة وخطورة انتشارها في خلد طرفي عقود التجارة الدوليةفيما مضي خاصة مع ما تتميز به معظم هذا النوع من العقود من استمراريتها لفترة طويلة بما يصعب معه التتبؤ بما قد يتعرض

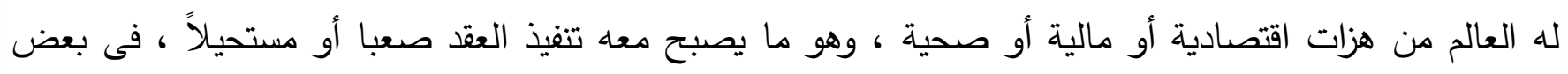
الأحوال فالعقد قد ينشأ صحيحا لكن يصبح قابلا للإلغاء بسبب انتفاء سببه أو موضوعه (101")، وهو ما تحقق بانتشار فيرس كورونا ، والتي يكون علي الطرفين البحث في مدي توافر شروط الإعفاء من المسئوليه عن عدم تتفيذه ، وهو ما سيكون ذو أهمية قصوي لدي طرفي عقود التجارة الدولية التي يتم إبرامها في وقت لاحق ، إذ سيدرك طرفي العقد أهمية ما يتم إدراجه من بنود في العقد واخضاعها للدراسة الدقيقة لتاثيرها علي حجم الدكاسب او الخسائر التي قد يمني بها ، بما لا يدع مجالا للصدفة، وهو ما يمكن معه القول بأنه سيكون لفيرس كورونا الفضل الكبير في التطور الذي ستشهده بنود عقود التجارة الدولية .

وبالتالي إذا ما توافرت الشروط السابقة في فيرس كورونا باعتبارة قوة قاهرة فإن المتعاقد يُعفي من المسئولية عن عدم تتفيذ العقد وتبرء ذمته من الالتزامات الملقاه علي عاتقه، والذي يكون مرجعه إن تنفيذ الدائن بالتزاماته التي جاءت بالعقد قد أصبحت مرهقة لدرجة غير معقولة وفقا للمجري العادي للامور قبل انتشار الفيرس والذي كان السبب الوحيد في وقوع الضرر مع انعدام علاقة السببية (102) ، فهنا يكون الخيار متروك للطرفين حسب طبيعة الاستحالة وعما إذا كانت مؤقته أم دائمه فلهم بعد دراسة الموقف الخيار إذ يلجأ الطرفين إلي إجراء المراسلات التمهيدية لإعادة النظر في مئري العقد بما يحقق التوازن العقدي الذي فُقد بفعل انتشار الفيرس وذلك بإعادة التفاوض حال تعلق الأمر بعائق مؤقتً، مع ضرورة أن يكون ذلك موضع معالجة بأحد بنود العقد" شرط إعادة التفاوض " (المطلب الاول) ، فإذا ما استجاب أحد الطرفين لرغبة الطرف الآخر لإعادة التفاوض وفقا لما استجد من ظروف انتشار الفيرس الذي تحول إلي وباءً عالميللرجة يوصف معها بالجائحة- وتبين أن من شأن استمرار هذه الظروف استحالة استكمال تتفيذ بنود العقد رغم محاولات الطرفين الحثيثة المقترنة بحسن النية لديهم لاعادة التوازن العقدي للعقد تكون هنا النهاية الحتميه للعقد المبرم ليجد الطرفين أنه لا مناص من فسخ العقد لاستحالة تنفيذه وذلك تطييقا لقاعدة " لا التزام بمستحيل" (المطلب الثاني ). المطلب الاول

101_ـ انظر :د/ احمد اشراقية ، الوسائل القانونية الخاصة بمواجهة آثار جائحة فيرس كورونا المستجد علي العلاقة التعاقدية : دراسة في القانونين

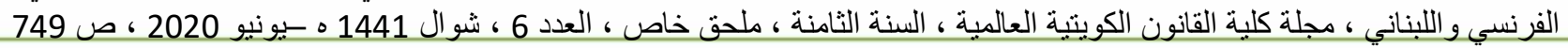

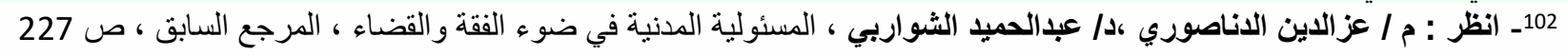




\section{إعادة التفاوض بثأن بنود عقود التجارة الدولية}

تحتل المفاوضات (103) مكانة راقية ومتقدمة لدي أطراف العقود سواء قبل إبرامها أو بعد البدء في التنفيذ للتصدر مشهد إبرام عقود التجارة الدولية ، إذ يعتمد عليها الطرفين باعتبارها الوسيلة التي تمكنهم من تقريب وجهات النظر بينهم بما يحقق المصالح المشتركة المرجوة من توقيع العقود ، فإذا كان للمفاوضات أهمية كبرى عند إبرام العقد للوقوف علي حل ناجع لكافة النقاط الشائكة التي تجول بخاطر كلا الطرفين وذلك سعي منهم إلي تنفيذ آمن وسلس للعقود وخاصة ما يتعلق منها بالتجارة الدولية لما لها من طبيعة خاصة ، إلا أن هذه الأهمية تتعاظم دورها بعد البدأ في تتفيذ عقود التجارة الدولية (104)،باعتبارها السبيل الذي يلجأ إليه الطرفين للمحافظة علي بقاء واستمرارية العقود ، لما قد يقدمه لطرفي العقد من مساعده علي حل كافة المشكلات التي قد تستجد أو قد تطرأ علي ظروف العقد من قوة قاهرة أو حادث مفاجئ قد يؤدي إلي إحداث خلا في التوزان العقدي ، وهو ما قد يصبح معه تتفيذ العقد إما مرهقا أو مستحيلاً، بحيث لا يكون هنالك مناص من إعادة إحياء المفاوضات بين الطرفين إذا ما دعت الظروف المحيطة بالتتفيذ اليذلك ، وذلك اعتمادا علي ما يمتلكه اعادة التفاوض من آلية لحماية العلاقة التعاقدية(105) وفقا لمبدأ حرية وحرمة العقد(106) . تجدر الإشارة إلي أنه علي الرغم من لجوء طرفي عقود التجارة الدولية إلي العقود النموذجية - التي تضعها المنظمات غير الرسمية للاسترشاد بها عند إبرام عقود التجارة الدولية - إلا أنه لا يمكن اعتبارها عقد من عقود الاذعان(107)، لما

103_لم تضع التشريعات الوطنية التي اشارة الي المفاوضات تعريف و اضحا لها كما ان هذه النصوص غير كافية لوضع تعريفا كامل وشاملا لها وذلك

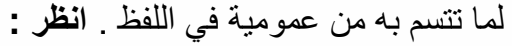

Osman (F), Les principes generaux de la lex mercatoria , L.G.D.J, PARIS , 1992, P.53 .

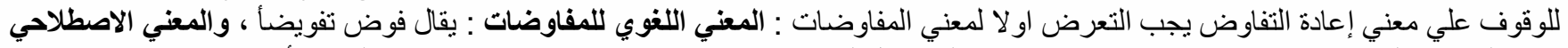

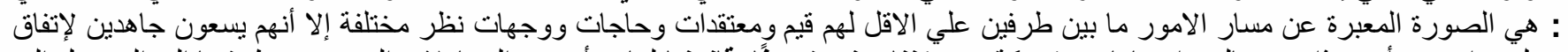

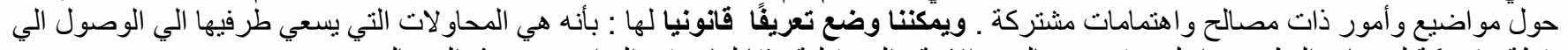

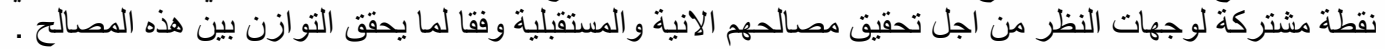

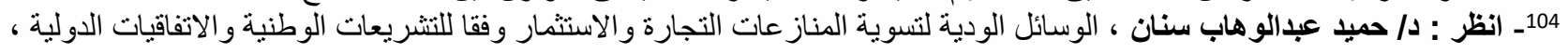

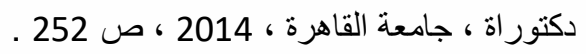

LORFING (p), La renégociation des contrats internationaux, Bruylant, 2011, p.9.

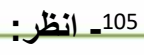

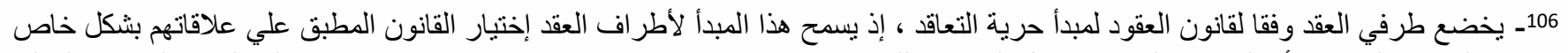

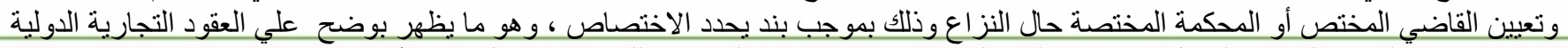

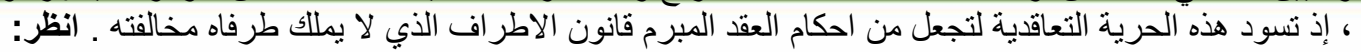
PALLUT (A) ,Les contrats commerciaux internationaux : problématique du 21ème Siècle , 09/04/2015.https://www.avocats-picovschi.com/les-contrats-commerciaux-internationaux-problematique-du21eme-siecle_article_465.html

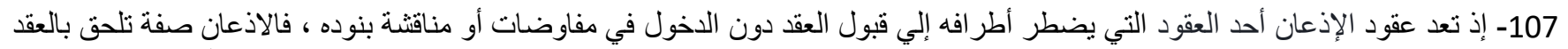

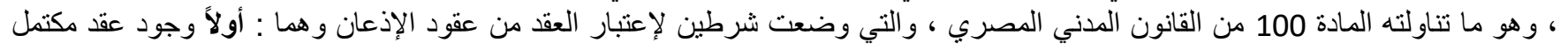


تشكله مرحلة التفاوض من أهمية قصوي لدي الطرفين بما يمنحه القدرة علي الوصول إلي التوازن العقدي المنشود بما لا يدع مجالا لتغليب التزامات أحد الطرفين علي حقوقه دون اعتراض أو مراجعة منه ،فالمراجعة أو التفاوض يمنح الطرفين فرصة تفسير العقد - بعد البدأ في التتفيذ - وفقا لما اتجهت إليه إرادة الطرفين وما يحقق مصالحهم ، مستعينين في ذلك برغبتهم الصادقة في استكمال تتفيذ العقد لحرصهم علي تفسير بنود العقد بما يجعل إعادة التفاوض أكثر يسرا وسهولة علي الطرفين وما يلحقها في مرحلة إستئناف التتفيذ علي الرغم من وجود معوقات تواجههم لانتشار فيرس كورونا ، لذا يحاول الطرفين إيجاد السبل التي تدعمهم في تجنب الآثار السلبية الناجمة عن اعتبار الفيرس عائقا يجعل من تنفيذه شاقاً او مستحيلاً ، وهو ما لا يتحقق في عقود الإذعان (108).

علي أن لجوأ طرفي العقد إلي إعادة التفاوض بينهم لجعل عملية التنفيذ أكثر مرونة يخضع لأحد أمرين هما إما أولاً : أن يتم الاتفاق علي إعادة التفاوض مسبقا ضمن المفاوضات التمهيدية لإبرام العقد ويتم إدراجه ضمن بنوده باعتبارة شرطاً تعاقديا أو اتفاقيا وهنا يعرف " بشرط إعادة التفاوض " لذا يستمد أساسه من إرادة الطرفين ، وبالتالي يلتزم الطرفين في حال ادراجه بتحديد شروط وحالات اللجوأ إليه تفصيلاً وعليه يلتزم الطرفين بهذه الثروط وتلك الحالات فلا يملكا الحيد عنهما(109) ،ويكون علي طرفي العقد أن يدركا أن إدراج مثل هذا الثرط يُرتب التزام جديدًا علي عاتقهم لذا يجب التحري والدقة عند إدراجه (110)، أو ثانيًا: أن يلجأ إليه الطرفين أثناء تتفيذ العقد - دون أن يدرج كشرط ضمن بنود العقد - والذي اكتسي بثوب المشقة أو الاستحالة ، هنا قد يري الطرفين أنه لا مناص من اللجوء إلي إعادة التفاوض بشأن بنود معينة يجب إعادة النظر فيها ليصبح معه التنفيذ ميسرا عليهم ، وهو ما يؤكد علي رغبتهم في إيجاد حل لكافة المشكلات التي تعيق التنفيذ ، علي أن الدخول في مفاوضات لايعني الوصول إلي نتيجه حتمية لصالح الطرفين بل يجب الأخذ في الاعتبار أن المفاوضات قد تبوء بالفشل حال عدم تعامل الطرفين بحسن نيه ممزوجة برغبة حقيقية

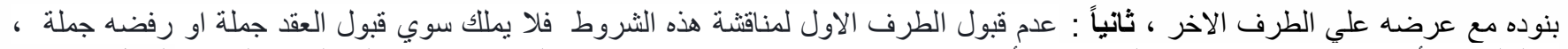

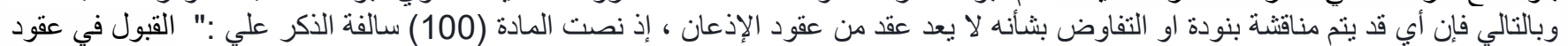

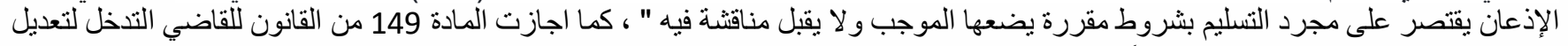

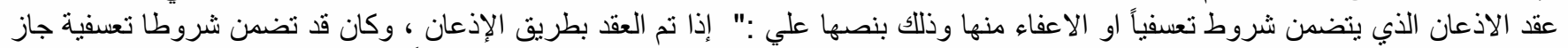

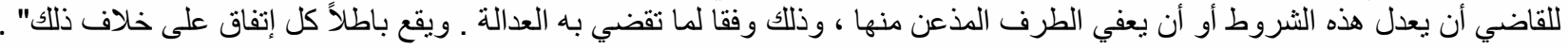

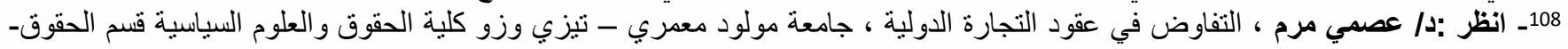

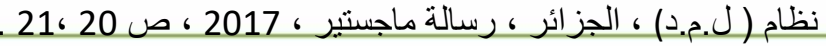

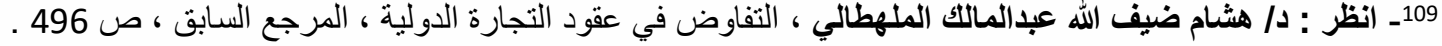

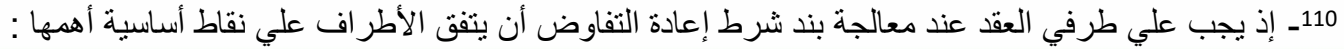

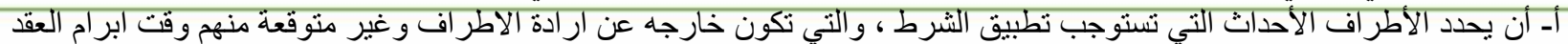

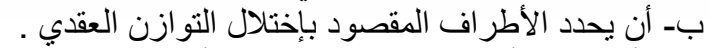

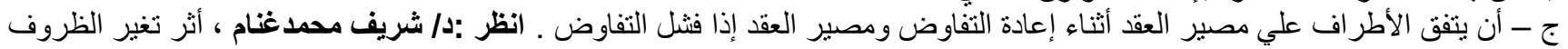

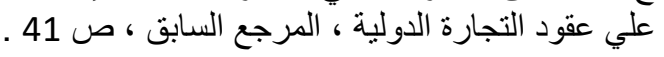




\section{منى عمار}

في إحداث تقدم ملموس في المفاوضات بشأن حل المشكلات التي تواجهم نتيجة انتشار فيرس كورونا باعتبارة سببا لتغير الظروف (111) و إلا فإننا نكون بصدد نتيجة محتملة(112).

ووفقا لما سبق فإن اختلاف اعتماد الطرفين علي أحد الوسائل السابقة كسند لاعادة التفاوض يكون من شأنه اختلاف في تبني الطرفين لأي من المفاوضات التكميلية أم المفاوضات التوزيعية (113)، فالاعتماد علي أيا من هذه الأنواع يخضع لطبيعة العلاقة بين الطرفين وتفهمهم لموقف تعرض العالم لجائحة الكورونا ومدي تأثير ذلك علي قدرتهم في تنفيذ العقد فقد يري الطرفين أنه من الأفضل الاستعانة بالمفاوضات التكاملية التي تقوم علي التفاهم والتكامل والإدراك الكامل لحجم الكارثة التي يتعرض لها اقتصاد العالم نتيجة انتثار الفيرس و أن عدم التعاون بينهم سيكون له آثار كارثية علي الطرفين وذلك سعيا منهم في الوصول إلي حل ناجع للمشكلات التي تواجه مواصلة تنفيذ عقود التجارة الدولية والتي تختلف حسب نوع العقد المبرم فاذا تعلق العقد بإنشاءات أو نقل للتكنولوجيا يسعي الطرفين إلي حل كافة المشكلات التظيمية التي تساعدهم علي مواصلة التتفيذ مع اتخاذ كافة التتابير الاحترازية التي تمنع ظهور الوباء بين العاملين في هذا المشروع ومن ثم انتشاره وتفشيه بينهم مما يمثل عائقا في تتفيذه . لكن لا يعني ذلك أن كافة المفاوضات قد تتم بهذه السهولة وذلك التكامل بل قد يكمن الغرض من هذه المفاضات في رغبة أحد الأطراف - وفقا لما يتمتع به من وضع مسيطر - في استغلال انتشار هذا الفيرس لتكون نقطة ضغط يستغلها من أجل الحصول علي أكبر قدر مكن من المغانم علي حساب الطرف الاخر معتمدا في ذلك علي قدرته في السيطرة والتحكم في مجريات أمور المفاوضات ، إذ يتسم هذا النوع من الدفاوضات بالتتاحر والصراع بين طرفي العقد فكلا منهم لدية رغبة في اجتذاب المفاوضات لجعلها تسير في اتجاه معين وغالبا لا يكون الغرض منها هو تحقيق المكاسب المادية بقدر ما قد تهدف إلي إضعاف الطرف الآخر لإخراجه من حلبة المنافسة في سوق معين و إنهاء نشاطه منعا لمواصلته نشاطا معين باعتباره منافسا محتملاً في هذا النطاق الجغرافي أو النوعي . وبالتالي فإن الاستراتيجية التي يعتمدها الطرفين هي التي تحدد نجاحها من عدمه علي أن يتم ذلك وفقا للإجراءات القانونية والطريق الذي رسمته الاتفاقيات الدولية من إخطار الطرف الآخر بانتشار فيرس كورونا باعتباره عائقًا يحول

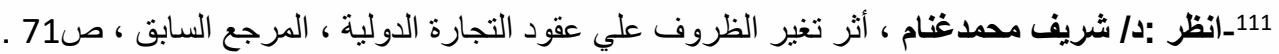

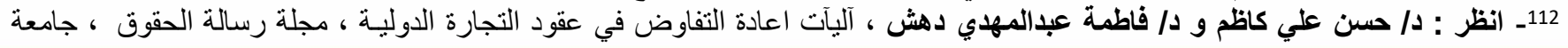

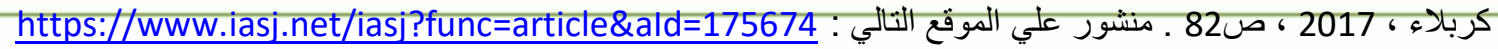

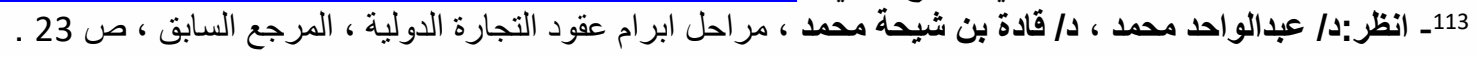


دون تتفيذ العقد أو مواصلة التنفيذ دون مشقة (أولاً) أو أن يكتفي هذا الطرف بتقديم ما يعرف بخطاب النوايا(ثانيًا) وأيا كانت الوسيلة إلا أن الهدف المرجو من ذلك يكمن في إعادة التوازن العقدي إلي عقود التجارة الدولية : أولاً : إخطار الطرف الآخر بانتشار فيرس كورونا: باعتباره عائقا حال دون تنفيذ العقد المبرم أو أن تتفيذه قد أصبح مرهقا له لدرجة أدت إلي الإخلال بالتوازن العقدي ، فعدم الاخطار علي الرغم من علم الكافة بانتشار هذا الفيرس تأسسيا علي إعلان منظمة الصحة العالمية علي أند وباء عالمى واصفة إياه بالجائحة وعلي التدابير الاحترازية الواضحة للكافة التي تتخذها الدول في كافة ارجاء المعمورة - لا تعد هذه الامور كافية وتغني عن الإخطار ، فقد تؤكد كافة الثواهد علي اعتباره عائقا لكن عدم الإخطار من الطرف الآخر يعني قدرته علي مواجهة هذا الوباء ومواصلة التنفيذ دون أن يشكل ذلك إرهاقا له ، فالإخطار يقوم علي اعلام الغير أو تبصيره عن عدم القدرة علي مواصلة التنفيذ وذلك لمنحه فرصة تجنب الاثار السلبية التي قد تتجم عن عدم مواصلة التنفيذ والتقليل من حدتها ، وبالتالي فإن عدم الإخطار يعد تنازلا صريحا عن كافة المكنات التي منحه إياه بنود العقد وفقا لشرط إعادة التفاوض " أو منحته له القواعد الدولية " التوازن العقدي " ، وبالتالي تَحمل جزاءات التخلف عن الإخطار(114)، علي أن يشتمل الإخطار علي الأسباب التي طالت تتفيذ العقد وسبل التغلب عليهاو تفادي التوقف عن التنفيذ(115).

ويجد الالتزام بالإخطار أساسه التشريعي في الاتفاقيات الدولية المنظمة لعقود التجارة الدولية (116)وكذا المبادئ الدولية الحاكمة لها والتي الزمت الطرف الذي يثكل انتشار فيرس كورونا عائقا بالنسبة له أن يتولي عملية الإخطار باعتبارة

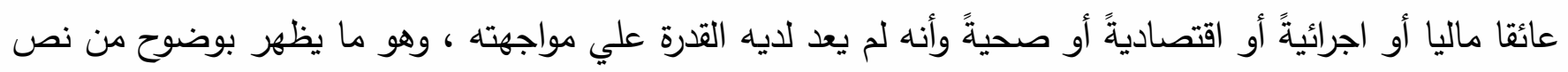
الفقرة (4) من المادة (79) اتفاقية الأمم المتحدة للبيع الدولي للبضائع(117) :" يجب علي الطرف الذي لم ينفذ التزاماته

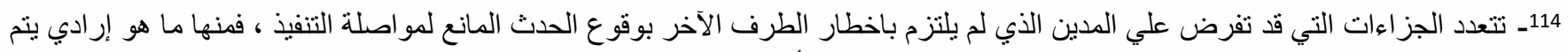

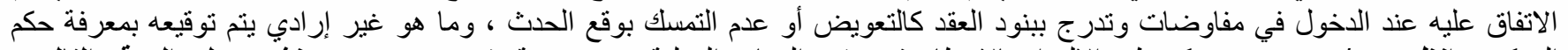

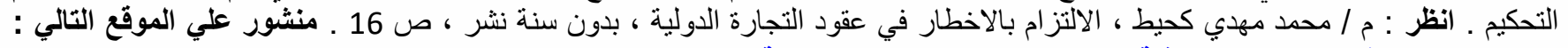

pdf.120643-170427/ابحاثثى//20\%:file:///D

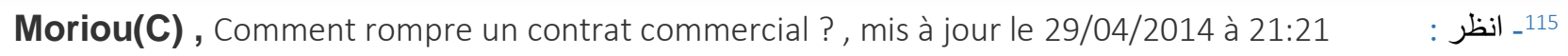
https://lentreprise.lexpress. -commercial_1509067.html

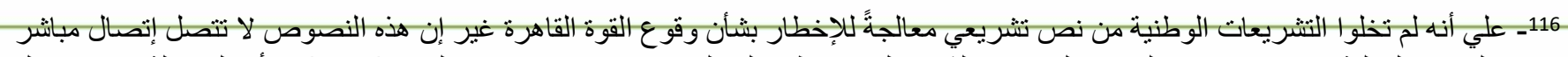

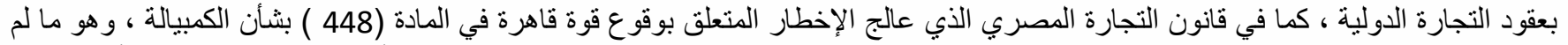

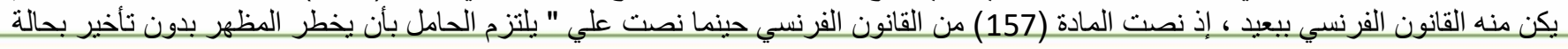
القوة القاهرة ".

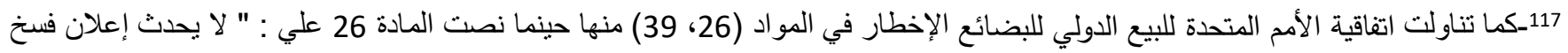

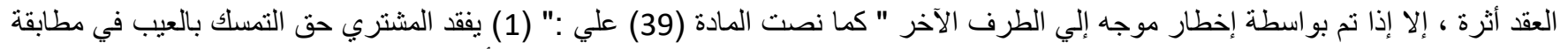

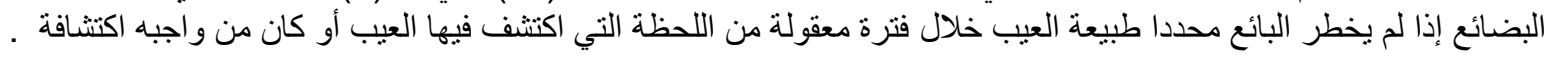


أن يوجه إخطارا إلي الطرف الآخر بالعائق وأثره في قدرته علي التتفيذ . وإذا لم يصل الإخطار إلي الطرف الآخر خلال مدة معقولة بعد أن يكون الطرف الذي لم ينفذ التزاماته قد علم بالعائق أو كان من واجبه أن يعلم به فعندئذ يكون مسؤولا عن التعويض عن الاضرار الناتجة عن عدم استلام الإخطار المذكور ". وفقا لذلك علقت الاتفاقية التزام الطرف المسئول عن الإخطار بالتعويض عن عدم الإخطار ولم تعلق التعويض علي عدم التوصل إلي حل للمشكلات الناجمة عن انتشار فيرس كورونا أثناء المفاوضات وهو ما يدفعنا إلي القول بأن التزام المسئول عن الإخطار هو التزام بتحقيق نتيجة وليس ببذل عناية.

كما أن الاتفاقية ألزمت الوصول الفعلي للإخطار إلي الطرف الآخر لتحقق العلم بوجود العائق ليس مجرد الإخطار بغض النظر عن وصوله من عدمه، وبالتالي يلتزم هذا الطرف بأن يتخذ كافة الإجراءات اللازمة لتحقق علم الطرف الآخر وذلك باتباع كافة السبل التي تمكنه من وصول الإخطار إلي الطرف الأخر ، فلم تضع الاتفاقية طريق معين للإخطار فيستوي أن يتم عن طريق المراسلات التقليدية أو الحديثة من خلال البريد الإكتروني أو التلغراف ، فوفقاً للمراسلات التي تمت في مرحلة التفاوض بشأن إبرام العقد يكون لدي الطرف الملتزم بالإخطار معلومات كافية عن السبيل الأنجع في المراسلة وأي السبل الأكثر استخداما من قبل الطرف الآخر في التواصل بينهم ، وهو ما يمكنه من أداء عملية الإخطار بسهولة ويسر بما يتفق مع نص الاتفاقية ،وهو ما يظهر بوضوح من نص الاتفاقية علي " وإذا لم يصل الإخطار إلي الطرف الأخر".

وهو ما لم يكن ببعيد عن مبادئ اليونيدروا في المادة 7-1-7 التي تتاولت القوة القاهرة كسبب للإعفاء من المسئولية في الفرتين (2،1) وجاءت في الفقرة (3) من المادة سالفة الذكر فألزمت الطرف المتعسر في التنفيذ - باعتباره مدينًا وفقا للمبادئ - أن يخطر الطرف الاخر - الدائن- بانتشار فيرس كورونا باعتباره عائقا يمنع التنفيذ أو مواصلته واعتبرت أن التقصير في اتخاذ هذا الإجراء يعد موجب للمسئولية يتحمل بمقتضاها تعويض الطرف الذي لم يتم إخطاره عن كافة الإضرار التي لحقت به نتيجة لتقصيرة ولم تكتفي المبادئ عند إلزامه بالإخطار وإنما وضع شرطا للإعفاء من المسئولية ممثلا في تمام الاستلام للإخطار من قبل الطرف الآخر فلا يعفي من المسئولية بمجرد الإخطار و إنما بتمام الاستلام لهذا الإخطار ، ووفقا لذلك يقع علي عاتق هذا الطرف أن يتخذ كافة الإجراءات التي تضمن استلام الإخطار بغض النظر عن الظروف المحيطة التي قد تشكل عائق يحول دون تمام استلام الإخطار ، ولعل الدافع من

(2) وفي جميع الأحو ال يفقد المشتري حق التمسك بالعيب في المطالبة إذا لم يخطر البائع بذلك خلال فترة أقصاها سنتان من تاريخ تسليم المشتري

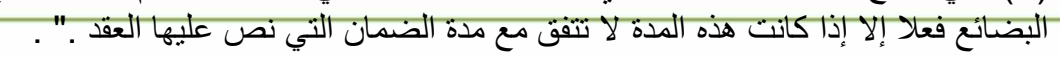


وراء تبني هذه المبادئ لهذا التوجه يرجع إلي العديد من المشكلات العملية التي نتجت عن الاستعانة بشرط الإخطار دون تمام استلام الإخطار كذريعة لتتصل من الالتزام والإفلات من المسئولية ،إذ كثيرا ما يلجأ الطرف المدين إلي الإكتفاء بالإخطار دون الاكتراث أو التحري عن العنوان الصحيح أو استلام الإخطار من عدمه مما نتج عنه ضياع حق الطرف الدائن في الرجوع علي الطرف المدين لعدم تمام التنفيذرغم عدم الإخطار وهو ما يظهر بوضوح من نص الفقرة (3) سالفة الذكر حينما نصت علي :" يلتزم المدين بأن يخطر الدائن بوجود الحادث ونتائجه علي قدرته علي التتفيذ ـ فإذا لم يتسلم الطرف الآخر الإخطار خلال مدة معقولة بعد أن يكون المدين قد علم بالحادث أو كان في وسعة العلم به ، فيسأل عن التعويضات المترتية علي عدم تسلم الإخطار " .

ونتيجة لإدرالك مبادئ اليوندروا لعظم الاثار السلبية التي تتتج عن عدم الإخطار فقد منحت الطرف الآخر بالاضافة إلي حقه في المطالبة بالتعويض عن الضرر الذي لحق به نتيجة عدم الإخطار فإنها قد منحته اضافة لذلك مُكنة اتخاذ كافة الإجراءات المتعلقة بإنهاء العقد أو التوقف عن تتفيذ الالتزامات المقابلة أو المطالبة بفوائد مستحقة ، وهو ما يظهر بوضوح من نص الفقرة (4) من المادة سالفة الذكر من مبادئ اليونيدروا حينما نصت علي :" ليس في هذه المادة ما يمنع أي طرف من ممارسة الحق في إنهاء العقد أو التوقف عن التنفيذ أو المطالبة بفوائد عن المبالغ المستحقة " ، وبالتالي لا يجوز له الجمع بين إنهاء العقد أو التوقف عن تنفيذ التزاماته والحصول علي الفوائد فلا مجال هنا للحديث عن الجمع بين هذه المكنات فلطرف المتضرر وحده الخيار في اختيار أحد هذه المكنات ، فهي مكنات لا يجوز الجمع بينهم وفقا لطبيعتهم القانونية فالتوقف عن التنفيذ نتيجة طبيعية لإنهاء العقد فاستخدام المبادئ ل " أو " يعني الاختيار بينهم فلم تستخدم "و " التي تمنح الفرصة في الجمع •

علي أن تحديد معقولية الفترة التي يلتزم بها الطرف المسئول عن الإخطار - وفقا لما ورد باتفاقية الأمم المتحدة بشأن البيع الدولي للبضائع ومبادئ اليونيدروا - لا تستتد الي معيارا محددا يمكن الارتكان إليها لتحديد عما إذا تم خلا الفترة المعقولة لذايمكن الاعتمادعلي معيار الرجل العادي ، وبالتالي يجب أن يتم الإخطار خلال فترة محدة لاحقة علي ظهور فيرس كورونا وترتيب آثاره بمنع مواصلة التنفيذ أو البدأ فيه وتختلف الفترة المعقولة من دولة لاخري وحسب نوع العقد التجاري الدولي ، ففي عقود الإنشاءات الدولية قد يرتب الحدث آثاره خلال فترة لا تتجاوز بضع أيام في دولة يتفشي و ينتشر بها الفيرس بشكل كبير لعدم اتخاذ الإجراءات الاحترازية في الوقت المناسب وبالثكل المناسب كما هو الحال في إيطاليا وإسبانيا بينما تراخي انتشار الفيرس في مصر بالثكل الملحوظ لسرعة اتخاذ الدولة المصرية لتدابير 
إحترازية سريعة وناجزه ، وهو ما يمكن معه القول باعتبار فيرس كورونا عائقًَ يستحيل معه التتفيذ في دولة ولا يعتبر كذلك في دولة أخرى ، بينما إذا تعلق الأمر بعقد البيع الدولي للبضائع فإن انتشار هذا الفيرس يشكل عائقَ بالنسبة لكافة الدولة لما اتخذته الدول من تدابير احترازية ممثلة في غلق حدودها لتصبح كل دولة معذولة عن جارتها وهو ما يستحيل معه حرية نقل البضائع بينها وتنفيذ العقد .

تجدر الإثارة إلي أن إهتمام الاتفاقيات الدولية المعنية بعقود التجارة الدولية لم يكن بحض الصدفة ، بل كان نتاج ما أفرزه الواقع العملي من مشكلات تبحث عن حل لمساعدة التجارة الدولية علي الانتشار و ممارستها بحرية وسهولة ، ولعل الغرض الرئيسي من وراء الإخطار يكمن في الرغبة في منح الطرف الدائن فرصة اتخاذ كافة الإجراءات الكفيلة بتدارك الآثار السلبية الناجمة عن انتشار فيرس كورونا وما لحق ذلك من توقف الطرف الاخر في العقد عن الوفاء بالتزاماته وذلك في محاولة منه لتقليل حجم الخسائر (118) ، خاصة إذا كان هناك عقود أخرى ترتبط بصورة مباشرة أو غير مباشرة بالعقد المبرم ، بما يمنح الطرف الآخر فرصة الدخول في مفاوضات مع الأطراف المعنية بالتنفيذه في الوقت المناسبة بما لا يحمله وطأة التأخير في اتخاذ الإجراءات الكفيلة بحمايتة من الرجوع عليه بالتعويض من قبل هذه الاطراف ، بمايملكه من الوقت الكافي لحل كافة المشكلات التي قد تعتري التنفيذ من خلال اعادة التفاوض وذلك لإعادة التوازن العقدي الي العقد الذي فقده نتيجة انتشار وباء فيرس كورونا ، علي أنه لم يتدخل المشرعين الوطني أو الدولي لتحديد مواصفات محددة أو شكلا معين للأخطار فكل ما تطلبه هو أن يتم إخطاره بانتشار فيرس كورونا ونتائج ذلك علي التنفيذ دون أن يُحدد صيغة معينة أو شكلا محددًا او لغة ما ولعل ذلك مرجعة هو ما تتصف به الحياة التجارية من سرعة في التطور بمايقتي مزيد من المرونة في التعامل ، علي أن الإخطار لا يعطي للطرف الآخر الحق في التوقف عن التنفيذ بل عليه مواصلة التتفيذ الي حين قبول إعادة التفاوض من الطرف الآخر • فإذا ما تمت عملية الإخطار كما ينبغي فان هناك مرحلة أخرى تبدأ وهي مرحلة قبول إعادة التفاوض التي يجب أن تتم خلال الفترة التي قد تحدد مسبقًا من قبل طرفي العقد فلا يعقل أن يتم تعليق القبول لفترة قد تتجاوز فترة انتشار الفيرس - مما ينتج عنه إعادة التوازن العقدي المفقود بسبب انتشار فيرس كورونا ، وبالتالي انتهاء الغرض منها - أو ينتظر إلي حين انتهاء فترة تتفيذ العقد خاصة إذا كان التنفيذ قد شرف علي الانتهاء ، علي أن الوسيلة التي يعتمد عليها الطرف الآخر للقبول قد تتم بناء علي اتفاق مسبق بين الطرفين أو بأي وسيلة يرى الطرفين فاعليتها في تحقيق ذلك 
بسهولة ويسر فقد يكفي القبول من خلال اتصال هاتفي أو المراسلة عن طريق البريد الالكتروني ، فما يحكم الوسيلة هو طبيعة العلاقة القائمة بين الطرفين وما يملكان من رغبة في التعاون بينهم أم أن العلاقة تشهد توترا او عدم رغبة في التعاون •

ثانيًا - خطاب النوايا بثأن انتشار فيرس كورونا :يهدف هذا الخطاب إلي تعبير الطرف الذي تعرض لانتشار فيرس كورونا عن رغبته في إيقاف الإجراءات التمهيدية السابقة علي الدخول في مفاوضات و استكمالها لإبرام العقد إذ اصبحت شاقةً أو مستحيلة ، وهو ما ينطبق علي عملية التتفيذ التي تعقب إبرام العقد في ظل استمرار انتشار الفيرس ، لذا يلجأ الطرف الذي بادر برغبته في الدخول في مفاوضات قبل انتشار فيرس كورونا أن يوجه إلي الطرف الآخر خطاب نوايا ملحق بشأن صعوبة مواصلة التعاون بشأن تبادل المعلومات لإبرام العقد التجاري الدولي نظراً لتعرض البلاد لجائحة الكورونا، فلا يوجد ما يلزم الاطراف بالاستمرار في التفاوض او إبرام العقد دون إبداء الاسباب فهي تقتقر إلي القيمة القانونية الملزمة وذلك تاسيسا علي مبدأ حرية المفاوضات المأخوذ به من قبل القضاء المصري والفرنسي

ووفقا لما سلف فإن الغرض من خطاب النوايا يتعلق بإيقاف إجراءات الاخول فى مفاوضات لإبرام أحد عقود التجارة الدولية لانتثار فيرس كورونا وصعوبة الاتصال وتبادل المعلومات ونكون بصدد مرحلة التفاوض وما يسبقها من اجراءاتموضوعية ، أما فيما يتعلق باخطار الطرف الاخر عن وجود حدث فيرس كورونا وانتشاره باعتباره عائق يحول دون التتفيذ أو أن مواصلته سيلحق به المشقة فهنا يوجه خطاب يعبر فيه عن رغبته في إعادة التفاوض بشأن بنود معينه في العقد بغرض إعادة التوازن العقدي إليه ، موضحا بها المشكلات التي تعرض لها التنفيذ و وجهة نظر في حلها شارحا كافة أبعاد الشكلة وسبل حلها بما يحقق مصالح الطرفين دون إجحاف علي أحد كالبنود المتعلق بالاسعار وفق سقف محدد(120).

ويثور التساؤل حول فاعلية خطاب النوايا في دعوة الطرف الآخر في إعادة التفاوض لإعادة التوازن العقدي إلي العقد المبرم أم أن هذا الخطاب قاصراً علي الدعوة إلي الدخول في مفاوضات سابقة علي إبرام العقد وحسب ، فعلي الرغم

119_ انظر : أ / مها محسن علي السقا ، مبدأ حسن النية في مفاوضات عقود التجارة الدولية، المرجع السابق ، ص 85 .

: 120 - 120 انظر : Mekki (M), De l'urgence à l'imprévu du Covid-19: quelle boîte à outils contractuels, AJcontrat 2020, 2020,p.164. https://mustaphamekki.openum.ca/files/sites/37/2020/04/la-boite-a-outils-contractuels.pdf 
من شيوع استخدام خطاب النوايا عند البدأ في الإجراءات السابقة علي التفاوض بشأن إبرام العقد إلا أنه يمكن الاستعانة بخطاب النوايا ليكون وسيلة لدعوة الطرف الآخر إلي التفاوض خاصة إذا كانت العلاقة التي تربط الطرفين في بدايتها أو ليست بالقوة الكافية والتي بموجبها يحتاج الطرف الأخر إلي بعض الإيضاحات ولوضع الخطوط العريضة من أجل البدأ في الدفاوضات ، وهو ما يتقق مع وظيفة الإخطار والغرض منه ، علي أن خطاب النوايا لا يستند إلي بنود العقد و إنما يستتد إلي رغبة الطرف الآخر في إيضاح الصورة كاملة بشأن انتشار فيرس كورونا وما يشكله من عائق وما يخلفة من آثار قد لا تدور في خلد الطرف الآخر، و لعل لجوأ أحد الطرفين لخطاب النوايا مرجعة طبيعة العلاقة السطحية أو غير المستقرة بينهم ، وهو ما يختلف عن الإخطار الذي يقوم علي العلاقة التي تربطه بالطرف الآخر ورغبة في مساعدته علي حل كافة المشكلات التي تواجه الطرف الآخر ، وأيا كانت الوسيلة التي يستعين بها الطرفين لإعلام الطرف الآخر بحدث انتشار فيرس كورونا فكلاً من الإخطار وخطاب النوايا يؤديان نفس النتيجة ، إلا أن التسمية تختلف حسب علاقة الطرفين وحسب ما إذا تم الانتهاء من المفاوضات ، وعلي إثر ذلك يتم إبرام العقد أي أنها مرحلة لاحقة علي إبرام العقد ، أما خطاب النوايا فقد درج العمل علي أنها مرحلة سابقة علي التفاوض لا ينتج عنها أي التزامات أو مسئولية قانونية بخلاف الإخطار الذي ينتج أثره بمجرد إرساله وفقا لاتفاقية الأمم المتحدة وبتمام إستلامه وفقا لمبادئ اليونيدروا .

و أيا كانت الوسيلة المتبعة لاخطار الطرف الآخر بانتشار فيرس كورونا واعتباره عائقا وفقا للظروف المحيطة ، إلا أن هذه السبل ينتج عنها أحد أمرين أما أولاً: أن يقبل الطرف الآخر اعتبار فيرس كورونا عائقا - يتوافر به شروط انتفاء المسئولية - مما يصبح معه التنفيذ مرهقا أو مستحيلا ، وبالتالي لا مناص من إعادة التفاوض بشأن بعض بنود العقد الجوهرية لحل ما يعتري التنفيذ من صعوبات ، أو ثانياً: أن يرى الطرف الآخر عدم رغبته في ذلك لإلزام الطرف الآخر بالتتفيذ رغم الاستحالة أو الصعوبة مستعينا بينود العقد التي قد تمنحه الحق في التفاوض أو أنهاء العقد .

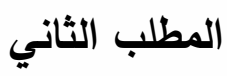




\section{إنهاء عقود التجارة الدولية لإنتشار فيرس كورونا}

تخضع عقود التجارة الدولية لمبدأ واحد مثلها في ذلك مثل كل شئ مادي وما تخضع له من فلسفة ، إذ يبدأ كفكرة ويمر بمرحلة التفاوض ثم إبرام العقد وانتهاءً بنهايته مثله في ذلك مثل كل شيء(121)، فنهاية العقد قد تكون طبيعية بالانقضاءبتنفيذ بنوده المتفق عليها سلفًا ، وهو ما يتمناه الطرفان حين الشروع في إبرامه و يحقق الفائدة المرجوة منه ، وهو ما لا يشكل مشكلة لكن قد يرجع إنهاء العقد إلي ظروف خارجة عن إرادة طرفيه كما لو واجه التنفيذ عائق انتشار فيرس كورونا باعتبارة قوة قاهرة بما يجعل التتفيذ مستحيلاً ، ولعل ذلك هو ما يعد أكبر المخاوف التي تسيطر علي طرفي العقد عند الدخول في مفاوضات أو إبرام العقود ، خاصة وأن هذا النوع من العقود يستمر تتفيذه لفترة قد تمتد لسنوات طوال ، كعقود الإنشاءات وعقود نقل التكنولوجيا ، وهو ما يجعل من فيرس كورونا وانتشاره أمرا غير متوقع بالنسبة لأطرافه .

ولعل انتشار فيرس كورونا خلال الآونه الأخيرة قد وضع النهاية الحتمية لبعض عقود التجارة الدولية التي حاولة البقاءوالانتصار علي ما يحيط بها من تحديات سابقة قد شكلت عائق حيال بقائها ، إذ أدي انتشار الفيرس إلي تعرض المشروعات والثركات المالكة لها إلي هزة عنيفة قد أودت بحياة كيانات اقتصادية كبري قبل أن تودي بحياة البشر في أرجاء العالم ، لذا لم يكن أمام العديد من المشروعات الكبري سوي أن تلجأ اإلي وقف تتفيذ العديد من العقود التجارية سواء علي المستوي الوطني أو الدولي ، فكان لهذا الفيرس القول الفصل حول مواصلة التنفيذ من عدمه لما له من تأثير قوي ومباشر علي تتفيذ عقود التجارة الدولية دون سواها ، وهو ما دفعها إلي اللجوء إلي الطريق الذي لا تملك ان تسلك سواه بأن تتهي حياة هذه العقود وهو ما يمكن أن نصفه" بالموت الرحيم لعقود التجارة الدولية"، سواء تم ذلك بناء علي اتفاق الطرفين بعد إعادة المفاوضات بينه(أولاً)- بناء علي رغبة أحد الأطراف أو هما معا - أو كان ذلك بناء علي رغبة أحد الأطراف دون سواها(ثانيًا)، علي أحد طرفي العقد يملك الحق في استرداد ما تم دفعه إذا تم التتفيذ

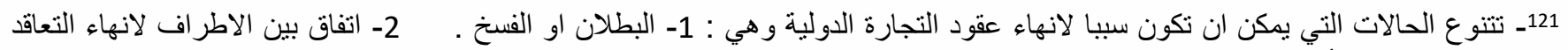

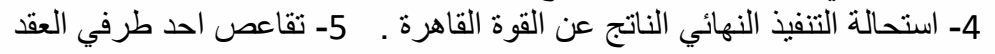

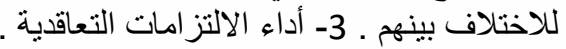

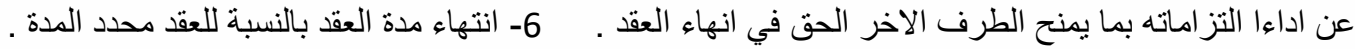
7- حدوث ظروف موضوعية معينة منل وفاة شريك منعاقد أو دخول أحد الاطر اف في إجر اءعات الاعسار او الافلاس . انظر : DeLY (F), LES CLAUSES METTANT FIN AUX CONTRATS INTERNATIONAUX, TERMINATION CLAUSES IN INTERNATIONAL CONTRACTS, RDAI/IBL, N 7, 1997, p.806.

https://www.iblj.com/gratuit/71997801-836.pdf 
الجزئي للعقد ولعل هذه الحالة تتسم بالتعقيد(22) وهو ما يمكن أن يفهم من نص المادة 1352 من القانون المدني الفرنسي (123) إذ أجازت الاسترداد عندما يكون التنفيذ مستحيلاً علي أن يتم تقدير القيمة في يوم الارجاع والذي يخضع مهن مهن لحجم الإلغاء - إلغاء جزئي أو كلي للعقد وفقا للمادة 1229 من القانون المدني الفرنسي - فالإرجاع قد يشمل العربون والدفعات الأولي المدفوعه وذلك وفقا للشروط الوارده بالمادة 1352 وما يليها من القانون .

تجدر الإثارة إلي أن وقوع القوة القاهرة ينتج عنها أن عدم التنفيذ في ظل انتشار فيرس كورونا يكون مؤقتًا إلي حين تعافي العالم من انتشاره أو التأكد من عدم تعرض العالم لموجة جديدة أعنف للفيرس ، وهنا ستكون عقود التجارة الدولية أمام أحد الأمرين ، الأمر الأول : اما ستكون بصدد إعفاء من التتفيذ مؤقت يلتزم بعد الاتتهاء منها بمواصلة تنفيذ العقد مالم يكون من شأن هذا التأقيت في التنفيذ أن يؤدي إلي المساس الجوهري بتنفيذ العقد بحيث نكون بصدد تتفيذ عقد مغاير تمامً عن العقد محل التنفيذ ففي هذه الحالة لا مناص من الإعفاء الكلي من التتفيذ (124) ، الأمر الثاني : أو إعفاء كلي من التنفيذ لتعلق التفيذ بعقود يستحيل معها الإنتظار إلي تمام انتهاء الفيرس كما لو تعلق الامر بتوريد أدوية تساعد علي تجنب آثار انتشاره ، وأيا كان الأمر إلا أنه تبقي حقيقة مؤكدة ممثلة في أن فيرس كورونا قد نتج عنه تغيير غير متوقع في ظروف إبرام عقود التجارة الدولية بما جعل تتفيذها مرهقا مصحوبا في كثير من الاحوال بالاستحالة أو المشقة وهو ما يضع طرفي العقد بين خيارين هما مراجعة العقد للبحث عن مخرج أو إنهائه وهو ما عالجه القانون المدني المصري في المادة ( 165 ) حينما نص علي " يترتب على قيام السبب الأجنبى سواء أكان قوة قاهرة أم خطأ الدائن أم خطأ الغير، انقضاء الالتزام الملقى على عاتق المدين بموجب العقد، ذلك ينقضي العقد تبعا لوجود ذلك السبب، فإذا حصلت الاستحالة ينقضى الالتزام. " ، بينما تولت الفقرة (2) من المادة 1218 من القانون المدني الفرنسي امر معالجة التمييز بين حالات انهاء العقد كلياً في حالة وجود عائق نهائي وكلي وبين حالة اعتبار العائق مؤقتا أو جزئي ففي حالة وجود عائق نهائي وكامل ، يعفى المدين تمامًا من مسؤوليته بموجب العقد ويتم إنهاء هذا الأخير تلقائيًا ، وبالتالي يتم انهاء مسئولية طرفي العقد بموجب القوة القاهرة وتبرأ ذتهم وفقا للشروط الواردة بالمواد

Landivaux (L), Contrats et coronavirus : un cas de force majeure ? Ça dépend... ,op.cit.

123ـ اذ نصت المادة 1352 من القانون المدني الفرنسي علي : "La restitution d'une chose autre que d'une somme d'argent a lieu en nature ou, lorsque cela est impossible, en valeur, estimée au jour de la restitution."

124ـ انظر : د/ يسري عوض عبدالله ، العقود التجارية الدولية " مفاوضاتها ـ ابر امها ـ تتفيذها- دراسة تحليلية علي ضوء نظرية العقد في التشريع https://books-library.online/files/books-library.online-12051036Hc1H2.pdf

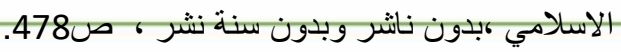




\section{منى عمار}

1351، 1351-1 من القانون المدني الفرنسي .أما في حالة وجود عائق مؤقت فإنه يتم تعليق العقد تلقائيًا ويتم إعفاء المدين من مسؤوليته وقت تعليقه ، ما لم يؤدي التعليق إلي التأخير في تنفيذ العقد بصورة تؤدي إلي إنهاء العقد ، فعندما يكون العائق جزئياً ، يُلغى العقد جزئياً أو يُخفض ، وذلك بتطبيق المادة 1351 من القانون المدني في هذه الحالة ، فتأثير القوة القاهرة قد يصبح قوي للغاية بما يترتب عليه إما الإفراج نهائياً عن مسئوليات طرفي العقد ، أو تعليق العقد حتى يختفي الحدث غير المتوقع والذي لا يقاوم(125)، وهو ما أكدت علية الغرفة المدنية لمحكمة النقض الفرنسية حينما :" اعتبرت أن عدم توقع الحدث مكونً للقوة القاهرة ، وذلك عندما لايمكن أن يدفع تأثيره " (126) . فهنا لا مناص من الرجوع إلي عقود التجارية الدولية المبرمة للوقوف علي بنوده للوصول إلي السبيل الذي يمكن الأطراف الخرج من هذه الازمة بأقل خسائر ممكنه ، فلا يمكن الحديث هنا عن مكاسب لأيا من الطرفين ، فالجميع في هذه الازمة قد مني بخسائر ، يختلف تاثيرها حسب قدرة الثركات علي التعافي منها وقوة مناعتها المالية ، وما تملكه من قرة علي حل كافة المشكلات التي تتعرض لها، وذلك لارتباط عقود التجارة الدولية بمجموعة من العقود المترابطة والتي تثكل في مجملها عقدًا دوليا ضمن مشروع و أحد كعقد نقل التكنولوجيا وعقود الانشاءات الدولية

ونظرا لعظم الآثار الناجمة عن الإنهاء دون اكتمال عقود التجارة الدولية فإنه من الواجب علي الطرفين الاتفاق علي إدراج البنود المتعلقة بالإنهاء بشكل صريح وواضح بما لا يدع مجالاً للثك أو التأويل كما يجب علي الطرفين إيضاح الحقوق و الالتزامات ، والتي يمكن الرجوع اليها باعتبارعدم تتفيذها خرقا للاتفاق يستوجب معه إنهاء العقد ، وهو ما يُمكن أحد الاطراف أن ينهي العقد دون الرجوع إلي القاضي حال ذكر عبارة " في حالة عدم تتفيذ العقد سيتم إنهاء العقد دون اللجوء إلي القضاء " ، لكن لا يمكن أن تسير الامور بين طرفي العقد وفقا لما قد سلف بمجرد التوقف عن التتفيذ بل يجب الوقوف علي الأسباب التي دعت إلي مثل هذا التوقف - من خلال المراسلات أو أي وسيلة يري الطرف الآخر سرعتها وقدرتها علي أدائها للمهمة بنجاح-مع الإرتكان إلي مبدأ حسن النية الذي يسيطر علي كافة المعاملات التجارية من خلال منح الطرف الآخر مهلة كافية لتصويب ما اعتري تتفيذ العقد من قصور ، علي إلتزام

Gastebled (É), Le clair-obscur de la force majeure en matière contractuelle face au Covid-19, op.cit . J.Cass civ 1 ere, 7 Mars 1966, no J.C.P , 1966. II.14877-14879.

: 126

127ـ انظر : د/ توفيق عارف توفيق ، إنهاء عقود التجارة الدولية وسلطة المحكم حيالها ، رسالة دكتور راه ، كلية الحقوق ، جامعة عين شمس ، 2015 
الطرف الذي يتجه إلي إنهاء العقد بإخطار الطرف الآخر موضحً به الانتهاكات التي طالت تتفيذ العقد وسبل التغلب عليها لمواصلة تنفيذه (128).

وقد يرجع عدم تتفيذ العقد أو المخالفة الجوهرية لبنوده إلي انتشار فيرس كورونا باعتباره قوة قاهرة ، هنا يعفي المسئول عن خطأ عدم التنفيذ أو مواصلته من المسئولية العقدية التي تقع علي كاهلة بموجب نصوص العقد والقواعد القانونية التي تقضي بتحمل المدين تبعه عدم التنفيذ ، والتي يتم تعطيلها في حال وقوع القوة القاهرة التي تخرج عن ارادة المسئول ، علي أن الاثر المترتب علي القوة القاهرة غير قاصر علي انتفاء المسئولية وحسب بل تمتد لتشمل انفساخ العقد لاستحالة التتفيذ ، وهو ما يتحقق نتيجة انتشار فيرس كورونا الذي حال دون تنفيذ البنود الجوهرية والأساسية في العقد بحيث لايقوم للعقد قائمة بدونها - فالعقد انثأ في الأساس من أجل تحقيقها و أنه كان الدافع وراء التعاقد - كما لو لو توقف عن تسليم البضائع لاستحالة نقلها بسبب الاجراءات الاحترازية المتخذه من قبل الدول ، وبالتالي فإن انتفاء المسئولية التعاقدية تتم من خلال إقامة الدليل علي انتفاء أساسها - من خطأ وضرر وعلاقة سببيه - وبالتالي فان وقوع القوة القاهرة تكون في حد ذاتها دليلاً علي انتفاء الخطأ من جانب المدين، لذا لا تقوم الحاجة إلي إقامة الدليل علي تحقق الخطأ(129) ،وبالتالي لا يجوز مسألته حتي مع تحقق الضرر لطرف الآخر لخروجها عن ارادته المقترنة باستحالة التنفيذ ، فجوهر المسئولية تقوم علي قياس مدي قدرة الاطراف علي الوفاء بالتزاماتهم دون أن يرافقها استحالة في التتفيذ لبنود جوهرية وليست ثانوية ، وهو ما يدفعنا الي البحث عن المعيار الذي يقوم عليه اعتبار بعض البنود جوهرية وأخري ثانوية ، وهل يجوز لأحد الأطراف إنهاء العقد بالإرداة المنفردة ، وهو ما لا يمكن تصوره بالنسبة لتسليم

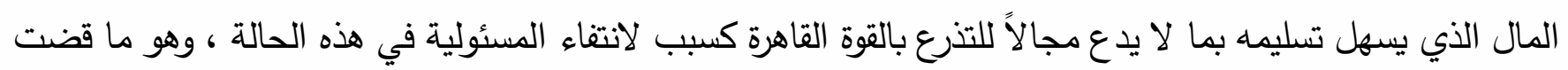
به محكمة النقض الفرنسية حينما قضت بأن المدين بمبلغ من المال ويتخلف عن أدائه فأنه لايمكن التحلل من هذا بادعاء القوة القاهرة (130).

Moriou(C), Comment rompre un contrat commercial ?, , op.cit .

- 128

129ـ انظر : د/ توفيق عارف توفيق ، سعد عبدالكريم ابو التم ، خصوصية إنهاء عقود التجارة الدولية ، مجلة علوم الثريعة و القانون ، العدد الثاني

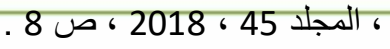
: 130 - انظر

Heinich (J), LE incidence de 'l épidémie de coronavirus sur les contrats de affaires: de la force majeure a le imprevision, Recueil dalloz 2020 ,p.611. 
فقد تتجه إرادة طرفي العقد إلي إنهائه لاستحالة تتفيذه أو أن التنفيذ أصبح مرهقًا لهما للرجة تجعل الإخلال بالتوازن العقدي هو السمة المسيطرة علي العقد وفي هذه الحالة يتفق طرفيه علي الإنهاء الآمن للعقد بعد إعادة التفاوض فيما بينهم بشأن الإنهاء ويستوي في ذلك أن يتم الرجوع إلي بنود العقد أو نزولاً علي رغبة الطرفين ، وهو ما يظهر بوضوح الإه من نص المادة (12) من اتفاقية الأمم المتحدة ، حينما نصت علي " يجوز تعديل العقد أو فسخه برضاء الطرفين " ، وفي هذه الحالة لا يكون هناك ثَ مشكلة يمكن أن تطفوا علي السطح بينه ، فنتيجة لإدراك الطرفين لعمق المسئولية التي تقع علي عاتقهم لتقصيرفي التنفيذ رغم استحالة التنفيذ ، يحاول الطرفين الحفاظ علي العلاقة القائمة بينهم والخروج الآمن من عملية إنهاء العقد دون مشاكل أو نزاع ، وقد يأخذ ذلك شكل المبادرة من قبل أحد الأطراف وقبول من الطرف الآخر ليكتب للعقد النهاية الرضائية ، ولكن لا يتم ذلك دون الالتزام بالاخطار (131).

وإذا كان هذا هو موقف اتفاقية الامم المتحدة فان مبادئ اليونيدروا قد أجازت لأحد طرفي العقد فسخ العقد بالإرادة المنفردة دون تعليقها علي موافقة الطرف الآخر ، شريطة أن يتم إعلانه بالفسخ وأن يستند إلي عدم التنفيذ الجوهري لأحد بنود العقد ، وهو ما يظهر بوضوح من نص المادة 7-3-1 المُعنونه (الحق في الفنخ ) حينما نصت علي :" يجوزلأي طرف فسخ العقد في حالة عدم التتفيذ الجوهري من جانب الطرف الآخر" ولم تكتفي عند هذا الحد بل وضعت عدة نقاط يجب الانتباه إلي توافرها من عدمه عند البحث فيما إذا كان عدم التنفيذ يطال بنودًا جوهرية (132) ، كما اجازت الفقرة (3) من المبادئ سالفة الذكر انهاء العقد من قبل الدائن إذا تاخر المدين عن التنفيذ ما لم ينفذ - المدين - العقد خلال المهلة المحدة بالمادة 7-1-5 ، والتي أجازت للدائن منح المدين المتوقف عن التنفيذ مهلة إضافية

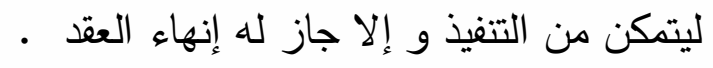

: انظر

Center du commerce international , Contrats-types destinés aux petites entreprises, un appui juridique pour s'engager dans le commerce international , Genève 2010, p.20 .

132- إذ أوضحت الفقرة (2)من المادة 7-3-1 من المبادئ المتعلقة بالعقود التجارية الدولية (مبادئ اليونيدروا) أنه : " 2- يراعي بوجة خاص

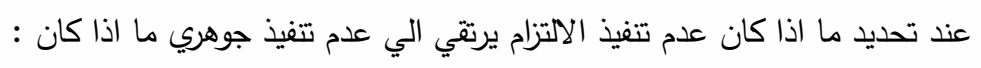

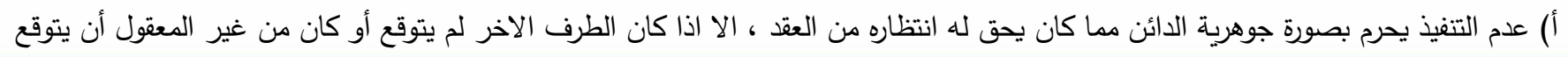

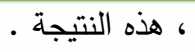

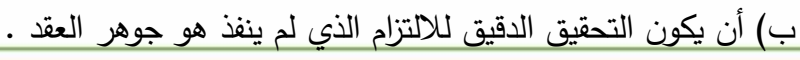

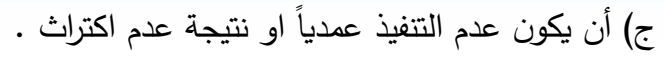

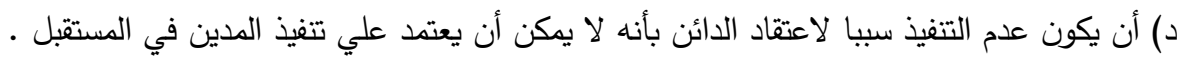

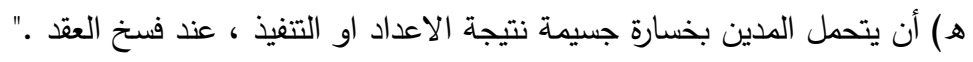


وبالتالي فإن إنهاء العقد لا يتم لمجرد التعسر في التنفيذ بل يجب أن يكون هناك مخالفة جوهرية عند تنفيذه،اشتراط جوهرية المخالفةليس لها علاقة بحجم المخالفة فقد تكون المخالفة جوهرية رغم بساطتها ،ولعل هذا التشدد الذي اعتمده قانون التجارة الدولية فيما يتعلق بالشروط التي تمنح الحق لأحد طرفي العقد في إنهائه مرجعة هو رغبته في حماية العلاقة العقدية ذات الطابع الدولي ووضع سياج من الضمانات تحول دون استغلال البعض لأسباب لا ترقي إلي مستوي المخالفة كذريعة لإنهاء هذا النوع من العقود خاصة مع ما تتسم به هذه العقود من ارتفاع تكلفتها المالية وارتباطها بأنواع أخري من العقود ، وبالتالي فإن أي حديث عن إنهاء لعقد تجاري دولي ينشأ عنه تبعات تؤثرسلبًا علي النواحي الاقتصادية والمالية للشركات المتعاقدة ، وهي في ذلك تثبه توابع الزلزال والتي لا تقل قوة وتأثيرًا عن الهزة الأولي ، وهو ما أدركه قانون التجارة الدولية وذلك سعي منه في خلق نوع من التوازن بين مصالح طرفي العقد ، فلا يمكن لطرفي العقد إنهائه لمجرد وجود عوائق في التنفيذ جري العرف علي وجودها أو لعدم الإرتياح في مواصلة التنفيذ رغم عدم وجود عوائق تجول دون ذلك ، فلا يمكن إخضاع أمر مواصلة التنفيذ العقد من عدمه لاهواء طرفيه . علي الن معالجة هذا الخلل الجوهري وذاك الثرط كسند لإنهاء عقود التجارة الدولية لم يكن ببعيد عن الاتفاقيات المتعلقة بالتجارة الدولية ،إذ تناولته اتفاقية الأمم المتحدة بشأن البيع الدولي للبضائع في المادة (25) منها حينما نصت علي :" تكون مخالفة العقد من جانب أحد الطرفين مخالفة جوهرية إذا تسببت في الحاق ضرر بالطرف الآخرمن شأنه أن يحرمه بشكل أساسي مما كان يحق له أن يتوقع الحصول عليه بموجب العقد ، إلا إذا لم يكن الطرف المخالف يتوقع مثل هذه النتيجة ولم يكن أي شخص سوي الادراك من نفس الصلة بتوقع مثل هذه الننتيجة في نفس الظروف" ، فعلي الرغم من معالجة المادة سالفة الذكر للمخالفة الجوهرية إلا أنها مازالت تتسم بالغموض فلم تضع تعريفا محددًا أو مدلولاً يمكن الإرتكان إليه عند البحث في أمر توافر هذه المخالفة الجوهرية من عدمه ،فكل ما تتاولته الاتفاقية هو تحقق الضرردون أن تضع معياراً محدداً للضرر معتمده في ذلك علي تحديد مقدار ما فقدة الطرف المضرور، وبالتالي يصلح الضرر لأن يكون سندا لإنهاء العقد بغض النظر عن درجته وهو ما منح الفرصه للفقه لتتخل ودراسته ليدلو بدلوه ، ولن يشفع لذاك الإغفال أن تضع الاتفاقية معيار الرجل العادي لتحديد سقف التوقعات التي يطمح الطرف المضرور الحصول عليها من وراء إبرام العقد الدولي ، وذلك لاعتمادها البين علي المعيار الثخصي لتوقع المخالفة دون أن تشير إلي إختلاف الظروف(133) . 


\section{منى عمار}

كما نصت المادة (72) منها علي :" إذا تبين بوضوح قبل حلول ميعاد تنفيذ العقد أن أحد الطرفين سوف يرتكب مخالفة جوهرية للعقد جاز للطرف الآخر أن يفسخ العقد " (134) ، ولم تكتفي الاتفاقية عند هذا الحد بل تتاولت المذكرة التفسيرية للاتفاقية تعريف المخالفة الجوهرية الموجبة للفنخ بأنه يجب أن يكون قد نتج عنها الحاق ضرر بالطرف الآخر من شأنه أن يحرمه بشكل أساسي مما يحق له أن يتوقع الحصول عليه بموجب العقد واعتبرت المذكرة التفسيرية أن وجود مخالفة جوهرية واحدة من طرفين يبرران إعلان فسخ العقد من جانب الطرف المضرور ، وهو ما تداركته مبادئ اليونيدرواحينما تناولت في المادة 7-3-1 جوهرية عدم التنفيذ (135) ، إذ وضعت معايير يتم الرجوع إليها للوقوف عما إذا كان عدم التنفيذ يطال بنود جوهرية من عدمه ، علي

أنها جاءت علي سبيل المثال لا الحصر بما يتيح للعرف التجاري الدولي التدخل ليضيف إليها معايير أخري يفرزها الواقع العملي(136) ، ويلاحظ أن الاتفاقية اعتمدت علي جسامة التصرفات التي تقع من الدائن ، وأيا كان السبيل الذي اتبعته الاتفاقية المعنية بالتجارة الدولية لمعالجة شرط جوهرية التنفيذ كسند للإنهاء من عدمه إلا أن مسلكهم يتفق مع نظام التجارة إذا لجأت إلي عدم وضع الثرط في قالب جامد يصعب معه معالجة ، ما يستجد في الواقع العملي الذي يتسم بالسرعة و التطور وهو ما يتفق مع الخصوصية التي تتمتع بها عقود التجارة الدولية من تغليب حرية إرادة المتعاقدين الم

و إذا كان ما سلف هو ما تبنته الاتفاقيات الدولية فقد تتاولها القانون الفرنسي بصورة ضمنية ، حينما إعتبرت المادتان 1147،1148 من القانون المدني الفرنسي من القوة القاهرة سببً في عدم جواز مطالبة المدين بالتعويض عن عدم التزامه بالتنفيذ ، إلا أن القضاء الفرنسي تبني موقفا متشدداً في إطار السكوت من قبل المشرع - في تقدير الثروط التي يجب توافرها في الحدث المترتب علي حدوث القوة القاهرة المنتجه لاستحالة التتفيذ ، فالقاضي لا يرتب علي وقوع

134ـ لم تقتصر الاتفاقية في معالجتها للمخالفة الجو هرية علي المادة 72 منها بل عالجة المخالفة الجو هرية أيضا في المواد أرقام 46 ، 49، 51، 64، . 70 70 72، 73: 73: 135ـ فعدم التنفيذ المتوقع يتساوي مع عدم التنفيذ وقت الإستحقاق ، و لا يعني ذللك الإرتكان إلي الثكوك التي قد تلتناب الطرف الآخر بشأن عدم قدرة

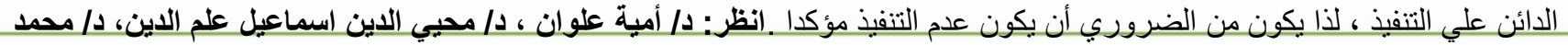

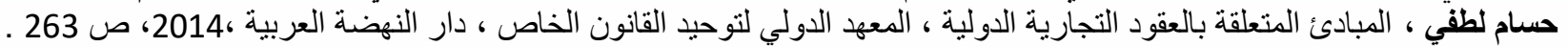
136ـ راجع نص الفقرة (2) من المادة 1-7-7 من المبادئ المتعلقة بالعقود التجارية الدولية (مبادئ اليونيلروا) . 


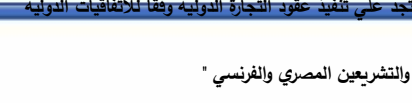 \\ منى عمار}

القوة القاهرة إنهاء العقد تلقائيا ، ولكن يتحري القاضي كل فرصة للابقاء علي العقد ومواصلة تتفيذه ، وبالتالي إذا كانت الاستحالة مؤقته فإنه لا يلجأ إلي إنهاء العقد بل يبقي تنفيذه معلقا علي انتهاء الحدث (137) .

\section{الخاتمة}

تعرض العالم في أواخر عام 2019 وعام 2020 إلي هجمه شرسة من فيرس كورونا لدرجة اعتبرتها منظمة الصحة

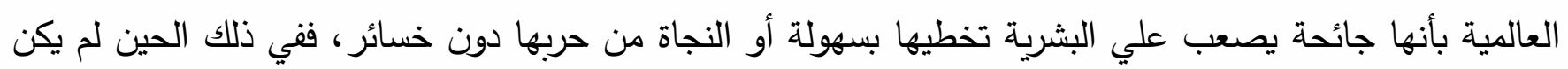

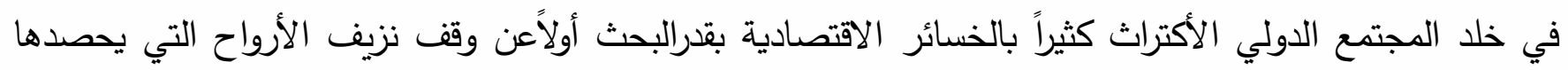

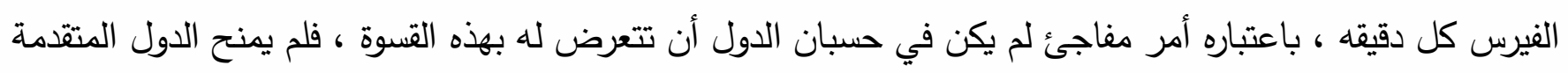

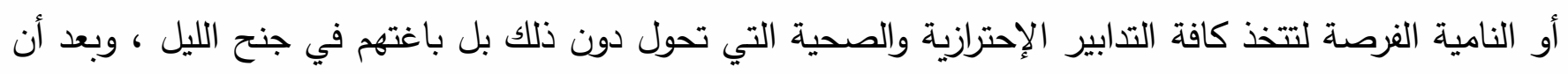

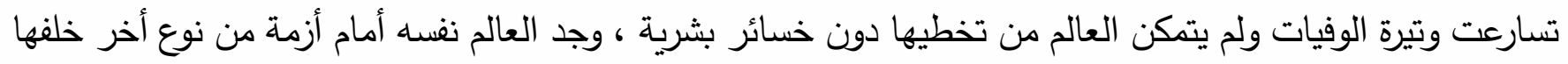

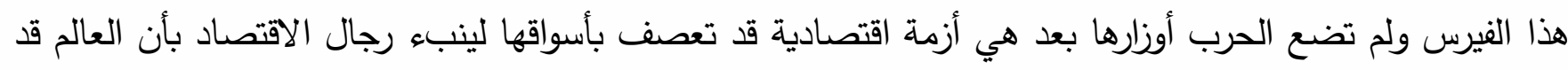

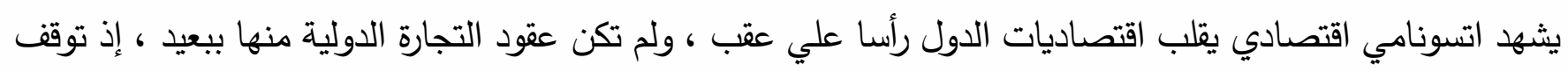
137ـ انظر : د/ شريف محمدغنام ، أثر تغير الظروف علي عقود التجارة الدولية ، المرجع السابق ، ص 59 ـ. 
العديد من أطراف عقود التجارة الدولية عن الوفاء بالتزاماتهج ، وهو ما دفع العديد من أطرافها إلي العودة لبنودها للبحث

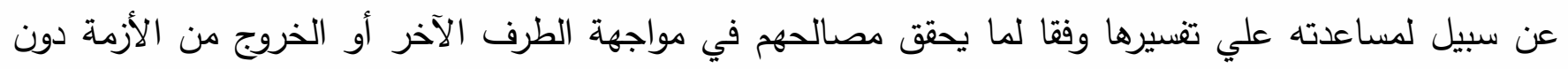

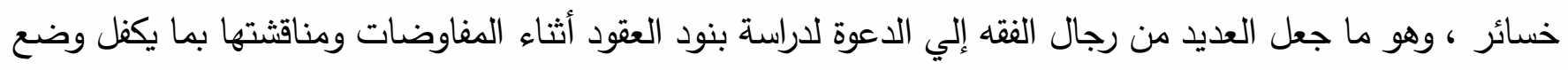

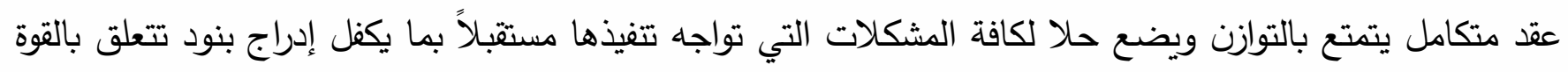

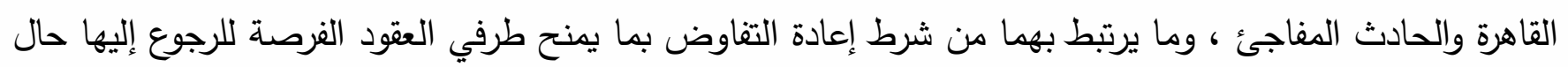
تحققها للوقوف علي سبل تخطيها والبحث عن حل يرضي الطرفين •

لذا كان من المهم للدول النامية دراسة هذا النوع من العقود بما يتوافق مع الاتفاقيات الدولية والتشريعات الوطنية

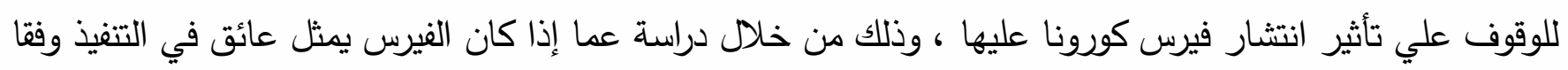
لشروط معين ، لإعتباره سببا للإعفاء من المسئولية الناجمة عن الاخلال بتتفيذ عقود التجارة الدولية لانتشار جائحة

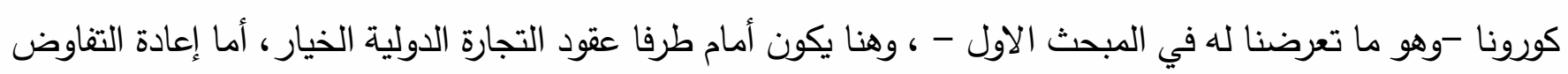

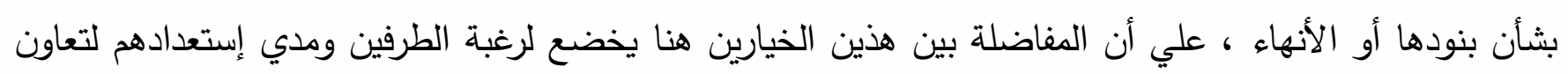

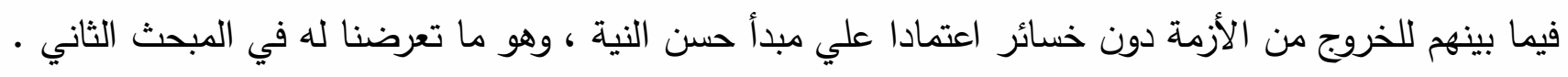

1- عقود التجارة الدولية هي أحد سبل تعزيز حركة التجارة وانسيابها بين الدول .

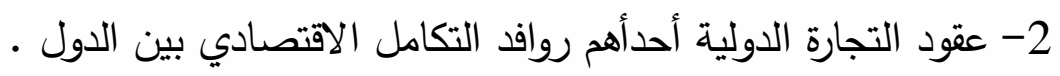
3-3 لا يقل تأثير انتثار فيرس كورونا عن تسونامي .

4- نتج عن انتشار فيرس كورونا تأثيرات سلبيه وخيمة علي اقتصاديات الدول ستحتاج إلي الكثير من الجهد لإعادة هيكلتها.

5- يجب علي الدول التدخل لمساعدة الشركات القائمة علي أراضيها علي تخطي أزمتها الاقتصادية . 6- معالجة الدول لأزمة كورونا ستكون محط أنظار المستثرين المحتملين لذا يجب علي الدولة المصرية

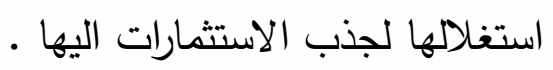


7- فيرس كورونا هو تحديا حقيقيا لاقتصاديات الدول سواء المتقدمة أو النامية .

$$
\begin{aligned}
& \text { 1- نوصي طرفا عقود التجارة الدولية بأن يولي بنود العقد اهتماما كبيرا عند الدخول في المفاوضات . }
\end{aligned}
$$

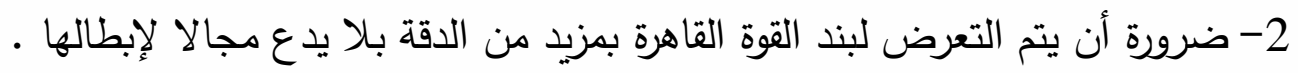

3- نوصي طرفا العقود التجارة الدولية التي تبرم بعد انتهار فيرس كورونا إدراج بند الأوبئة والأمراض كقوة قاهرة .

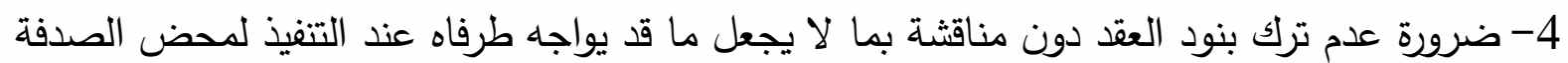

5- نوصي المشرع المصري أن يتولي معالجة القوة القاهرة بما يتفق مع أهميتها بموجب نصوص تشعل تشريعية معالجة

لكافة جوانبها .

\section{*Conclusion*}

The world was exposed to a fierce attack from the Corona virus in late 2019 and 2020 to the extent that the World Health Organization considered it a pandemic that it is difficult for humanity to easily overcome or survive its war without losses. At that time, the international community was not so much concerned with economic losses as much as looking first to stop The bleeding of lives that the virus reaps every minute, as a sudden matter that the countries did not think of being exposed to it with this cruelty. It did not give the developed or developing countries the opportunity to take all precautionary and health measures that prevent this, but rather surprised them in the misdemeanor of the night, and after the deaths accelerated and was unable The world who overcame it without human losses, the world found itself facing another kind of crisis left by this virus, and the war has not yet ended. It is an economic crisis that may strike its markets, so that economists predict that the world may witness an economic tsunami that turns the economies of countries upside down, and international trade contracts were not Far from it, as many of the parties to international trade contracts stopped fulfilling their obligations, which prompted many of its parties to return to their clauses to search for a way to help him interpret them according to what achieves The desire to confront the other party or get out of 
the crisis without losses, which is what made many scholars of jurisprudence to call for studying the terms of contracts during negotiations and discussing them in a way that guarantees the development of an integrated contract that enjoys balance and sets a solution for all problems facing its implementation in the future to ensure the inclusion of items related to force majeure and sudden accident And what is related to them in terms of re-negotiation, which gives the contracting parties the opportunity to return to it once it is achieved, to find out ways to bypass it and search for a solution that satisfies both parties.

Therefore, it was important for developing countries to study this type of contract in accordance with international agreements and national legislation to determine the impact of the spread of the Corona virus on it, through a study of whether the virus represents an obstacle to implementation according to certain conditions to consider it a reason for exemption from liability resulting from the breach in the implementation of contracts International trade for the spread of the Corona pandemic - which is what we discussed in the first topic - which gives the parties to international trade contracts the choice between renegotiating their clauses or termination, provided that the comparison between these two options here is subject to the desire of the two parties and their willingness to cooperate with each other to get out of the crisis without losses Based on the principle of good faith, which we discussed in the second topic.

\section{أولاًَ- المراجع العربية :}

1- أ / أمير فرج يوسف ، المسئولية المدنية والتعويض عنها ، طبقا لأحكام القانون المدني ، دار المطبوعات

الجامعية ، 2006 ـ الجيل

2- د/ أمية علوان ، د/ محيي الدين اسماعيل علم الدين، د/ محمد حسام لطفي ، المبادئ المتعلقة بالعقود التجارية

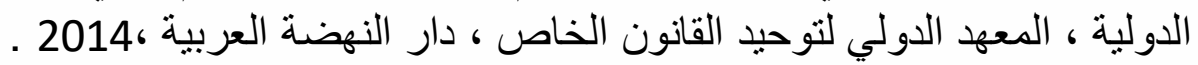

3- د/ توفيق عارف توفيق ، إنهاء عقود التجارة الدولية وسلطة الدحكم حيالها ، رسالة دكتوراه ، كلية الحقوق ،

$$
\text { جامعة عين شمس ، } 2015 \text {. } 2015
$$

4- د/ حسن عكوش ، المسئولية المدنية في القانون المدني الجديد ، مكتبة القاهرة الحديثة ، الطبعة الاولي

.1957

5- د/ حنان عبدالعزيز مخلوف ، العقد الدولية ،كلية الحقوق ، جامعة بنها ، 2010 .

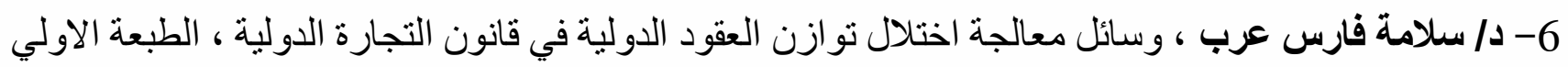

. 1999

7- د/ شريف محمدغام ، أثر تغير الظروف علي عقود التجارة الدولية ، أكاديمية شرطة دبي ، 2010/2009 
8- أ / مها محسن علي السقا ، مبدأ حسن النية في مفاوضات عقود التجارة الدولية ، المركز القومي للاصدارات

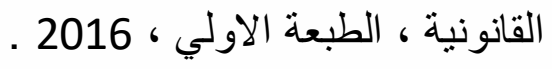

9- د/ محمد ابراهيم موسي، انعكاسات العولمة علي عقود التجارة الدولية ، دار الجامعة الجديدة ، 2007

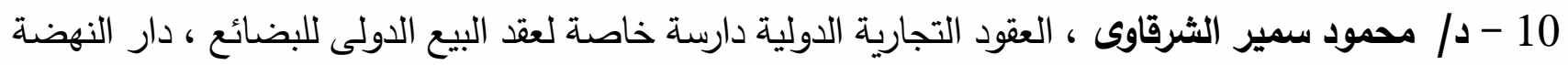

العربية - القاهرة ، 1992 - 192

11 - د / عبدالرازق السنهوري ،الوسيط في شرح القانون الدني الجديد ، نظرية الالتزام بوجه عام ، مصادر

الالتزام ، المجلد الاول ، دار النهضة العربية ، القاهرة / 1966 ـ 196

12 - د/ عبدالحكم فوده ، تفسير العقد في القانون المدني المصري و المقارن ، منشأة المعارف 2002 ، 200

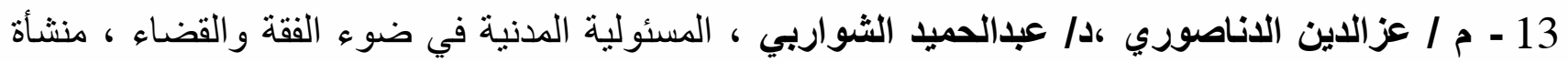

المعارف ، الطبعة السادسة ، 1997 .

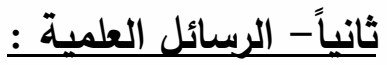

1- د/ بكاكير حسيبة ، عقود التجارة الدولية ، رسالة ماجستير ، جامعة عبدالرحمان ميرة ، كلية الحقوق والعلوم الساسية ، 2013/2012 . 2013

2- د / بلال عبدالمطلب بدوي ، مبدأ حسن النية في مرحلة التفاوضات قبل التعاقدية في عقود التجارة الدولية ،

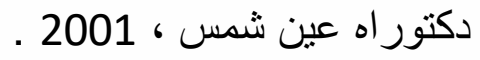
3- د/ حميد عبدالوهاب سنان ، الوسائل الودية لتسوية المنازعات التجارة والاستثمار وفقا للتشريعات الوطنية

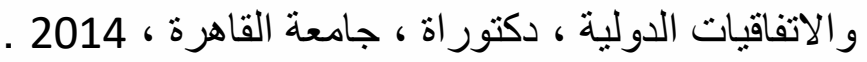

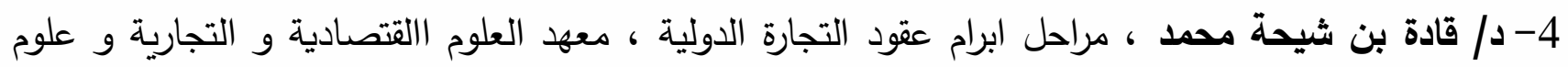
• التسير -الجزائر ، رسالة ماجستير 2018.2017 5- د/ عصمي مرم ، التفاوض في عقود التجارة الدولية ، جامعة مولود معمري - تيزي وزو كلية الحقوق والعلوم

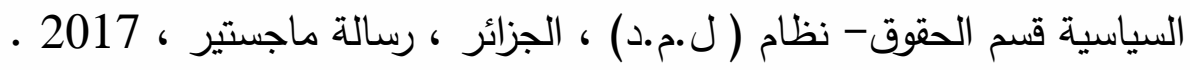

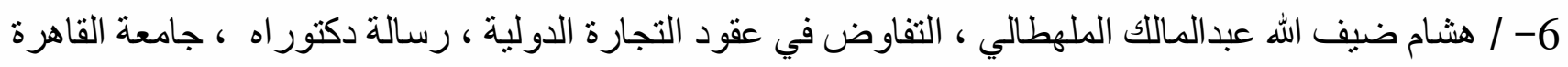
2015 7- د/ هني عبداللطيف ، حدود الاخذ بفكرة إعادة التقاوض في العقد " دراسة مقارنة" ، جامعة أبي بكر بلقايد ، الجزائر ، رسالة دكتوراه ، 2016/2015. 
1-د/ احمد اثراقية ، الوسائل القانونية الخاصة بمواجهة آثار جائحة فيرس كورونا المستجد علي العلاقة التعاقدية : دراسة في القانونين الفرنسي واللبناني ، مجلة كلية القانون الكويتية العالمية ، السنة الثامنة ، ملحق خاص ،

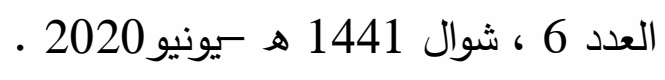

2- د/ توفيق عارف توفيق ، سعد عبدالكريم ابو الغنم ، خصوصية إنهاء عقود التجارة الدولية ، مجلة علوم

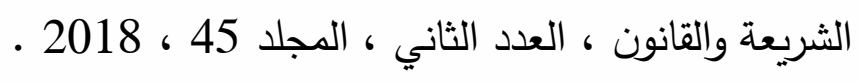

3- د/ حسن علي كاظم و د/ فاطمة عبدالمهاي دهش ، آليآت اعادة التفاوض في عقود التجارة الدولية ، مجلة

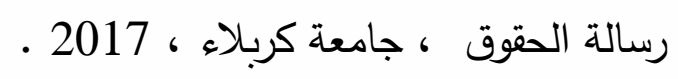

4- د/ حورية لشهب ، النظـام القانوني للعقود التجاريـة ، مجلة العلوم الإنسانية - جامعة محمد خيضر بسكرة ،

دولة الجزائر ، لعدد الثاني عشر ، نوفمبر 2007 ـ ـ ـ

لابعاً- المواقع العربية : دوله

covid-19-1 القوة القاهرة والتحكيم ، التحكيم الدولي ، تاريخ النشر 2020/3/19 منشور علي الموقع التالي : https://www.international-arbitration-attorney.com/ar/covid-19-force-majeure-and-

arbitration/

2- د/ محمد الخضراوي ، الاثار القانونية لفيروس كورونا المستجد علي العلاقات التعاقدية ، ص2 منشور علي الموقع التالي : file://D:/\%D8\%A7\%D8\%A8\%D8\%AD\%D8\%A7\%D8\%AB\%D9\%8A/\%D8\%9\%8A\%D8\% A9.pdf 3- م / محمد مهدي كحيط ، الالتزام بالاخطار في عقود التجارة الدولية ، بدون سنة نشر ـ منشور علي الموقع

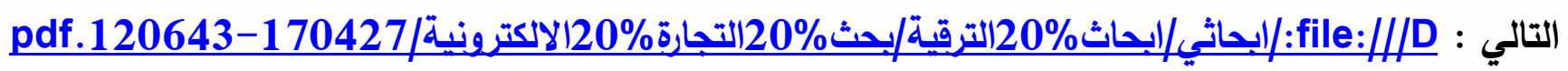
4-د/يسري عوض عبدالله ، العقود التجارية الدولية " مفاوضاتها - ابرامها - تتفيذها- دراسة تحليلية علي ضوء نظرية العقد في التشريع الاسلامي ،بدون ناشر وبدون سنة نشر • https://books-library.online/files/books-library.online-12051036Hc1H2.pdf 5-وكيبيديا الموسوعة الحرة ، الجائحة ،آخر تعديل لهذه الصفحة كان يوم 6 مايو 2020، منشور علي الموقع التالي : naln 


\section{https://ar.wikipedia.org/wiki/\% 8\%A7_(COVID-19)}

7-فيروس كورونا 2 المرتبط بالمتلازمة التنفسية الحادة الثديدة ، 27مارس 2020، منشور علي الموقع https://ar.wikipedia.org/wiki/\%D9\%81\%D9\%8A\%D8\%B1\%D9\%88\%D8\%B388: التالي

8-د/ مجدي محمد سيف عقلان ، التدابير الاحترازية في الثريعة الاسلامية ، بدون ناشر ، بدون سنة نشر ، ص

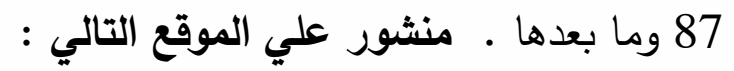

file://C:/Users/DELL/Downloads/46-181-1-PB.pdf

\section{خامساً- المواقع الاجنية :}

- Appel ICC, OMS, B20 au G20 pour une approche coordonnee de la crise sanitaire et economique de la pandemie., 25/03/2020, http://www.icc-france.fr/chambrede-commerce-internationale-actualite-7-601-Actualites.html

- Bamdé (A), La responsabilité contractuelle: régime juridique, 19 NOVEMBRE $\underline{2019}$ https://aurelienbamde.com/tag/force-majeure/

- Barbosa (A) , Les top 5 des obstacles au commerce international , $6^{\text {th }}$ aout 2019 https://www.intercountry.com/blog/les-top-5-des-obstacles-au-commerceinternational/

- Berg-Moussa (M) , Le Coronavirus est-il un cas de force majeure et/ou une cause d'imprévision ?, 04/03/2020. https://www.august-debouzy.com/fr/blog/1415-le-coronavirus-est-il-un-casde-force-majeure-etou-une-cause-dimprevision

- Canet (L), Coronavirus : comment répondre à la force majeure invoquée par la Chine dans ses relations commerciales, jeudi 27 février 2020 . https://www.village-justice.com/articles/coronavirus-comment-repondre-forcemajeure-invoquee-par-chine-dans-ses,33920.html 
- C.M. Schimithoff "International Business law, A new Law Merchant" Current law \& Social problems,P.129

www.ir,lawnet.fordham.edu/cgi/viewcontent.cgi

- DESERT (A) , Qu'est-ce qu'un contrat commercial ?, Focus sur les particularités légale du contrat commercial , Publié le 26/06/2019,

- https://www.toute-la-franchise.com/vie-de-la-franchise-A31940-qu-est-cequ-un-contrat-commercial.html

- $\operatorname{DelY}(\mathbf{F})$, LES ClAUSES METTANT FIN AUX CONTRATS INTERNATIONAUX, TERMINATION CLAUSES IN INTERNATIONAL CONTRACTS, RDAI/IBLJ, N 7 , 1997.

\section{https://www.iblj.com/gratuit/71997801-836.pdf}

- FONTANEAU (C), La formation des contrats internationaux, Article publié dans la Revue «Fiscalité Européenne et Droit International des Affaires » N 125 (Année 2001) http://www.fontaneau.com/?p=350

- Gagné (L), Les contrats commerciaux internationaux et les systèmes de droit civil et de common law, Revue générale de droit, Document généré le 11 avr. 2020 02:48 .

https://www.erudit.org/fr/revues/rgd/2002-v32-nrgd01658/1028054ar.pdf

- Gastebled (É), Le clair-obscur de la force majeure en matière contractuelle face au Covid-19, ublié le10/04/2020 - mis à jour le 10/04/2020 à 18H55

https://www.actu-juridique.fr/civil/obligations-contrats/le-clair-obscur-de-la-forcemajeure-en-matiere-contractuelle-face-au-covid-19/

- Godel (M), es contrats du commerce international, Cours du Professeur Jacquet, Institut de Hautes Etudes Internationales, Genève , 2019 . http://hei.stoessel.ch/dip/contrats_commerce_international_jacquet.pdf

- Guillaumond (R), La gestion des difficultés d'exécution résultant de force majeure ou d'imprévision, Colloque International Alger 26 mai 2014, ADAMAS 
- https://www.adamaslawfirm.com/upload/pdf/publications/707c59312ad17da1ac2 b01e.pdf

- Herau-Yang $(\mathbf{H})$, Coronavirus et contrats: force majeure, or not force majeure?, 01/03/2020 .

https://lepetitjournal.com/hong-kong/coronavirus-et-contrats-fmajeure-

- Landivaux (L), Contrats et coronavirus : un cas de force majeure ? Ça dépend... , le 20 Mars 2020,

https://www.dalloz-actualite.fr/node/contrats-et-coronavirus-un-cas-de-forcemajeure-ca-depend\#.XqqmM6gzY2w-

- Llamazares (0), Le Contrat International : 10 Questions Clés, Global Negotiator Blog , le 9 février, https://www.globalnegotiator.com/blog_fr/contrat-international-definition/

- Mathias Avocats, Covid-19 : un cas de force majeure ?, 20 mars 2020 https://www.avocats-mathias.com/actualites/force-majeure-impacts- contrat

- Mekki (M), De l'urgence à l'imprévu du Covid-19 : quelle boîte à outils contractuels , AJcontrat 2020, 2020,p.164.

https://mustaphamekki.openum.ca/files/sites/37/2020/04/la-boite-a-outilscontractuels.pdf

- Moriou(C), Comment rompre un contrat commercial ?, mis à jour le 29/04/2014 à 21:21 https://lentreprise.lexpress. -commercial_1509067.html

- PALLUT (A), Les contrats commerciaux internationaux : problématique du 21ème Siècle , 09/04/2015. https://www.avocats-picovschi.com/les-contratscommerciaux-internationaux-problematique-du-21eme-siecle_article_465.html 
- Wikipédia, Droit commercial international , 21 décembre 2018 ,

- https://fr.wikipedia.org/wiki/Droit_commercial_international

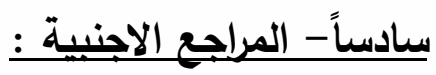

- Batiffol (H) ,Repertique de droit international contrats et conventions, Encycloprdie juridique ,Dalloz .

- Carbonnier (J), Les obligations, droit civil, Tome IV, PUE, Themis , 1994.

- FILALI OSMAN, Les principes generaux de la lex mercatoria, L.G.D.J, PARIS, 1992.

- $\quad$ GHESTIN (J), Traire de droit civil , la formation du contrat, 3 edition, L.G.D.J 1993 .

- Heinich (J), LE incidence de 'I épidémie de coronavirus sur les contrats de affaires:de la force majeure a le imprevision, Recueil dalloz 2020 .

- $\quad$ LORFING (p), La renégociation des contrats internationaux, Bruylant, 2011.

- $\quad$ LOUSSOUARN (Y) \&BREDIE (J.D), Droit du commerce international, paris 1969.

- Moury (J), Force majeure : eloge de la sobriete, Revue trimestrielle de droit civil , Dalloz , paris 2004

- H-P .Antomattei,contribution a l etude de la force majeure, pref.B. teyssie , L.G.D.J , 1992,NO49 .

- UNCTAD, Global trade impact of the coronavirus (COVID -19) epidemic, 4MARCH 2020 . سابعاً- المواقع الرسمية :

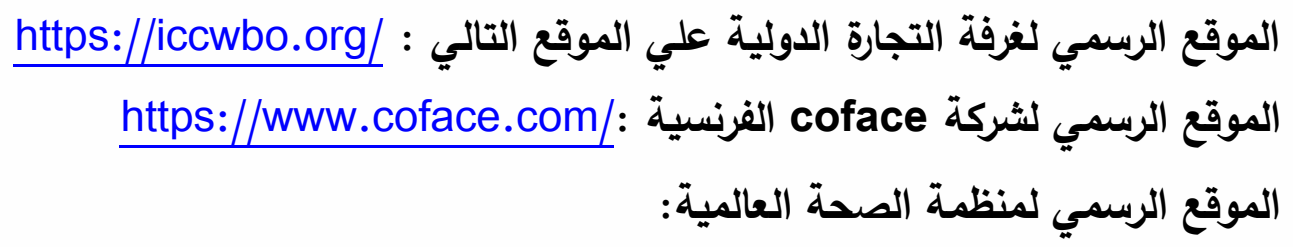

https://www.who.int/ar/about/what-we-do/who-brochure

- Center du commerce international, Contrats-types destinés aux petites entreprises, un appui juridique pour s'engager dans le commerce international , Genève 2010,

- La dimension juridique du commerce international http://www.intracen.org/uploadedFiles/intracenorg/Content/Redesign/Projects/PACIR_U EMOA/ITC-module 6.pdf 


\begin{tabular}{|c|c|c|}
\hline 1 & & 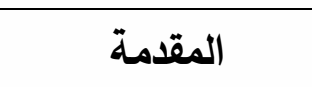 \\
\hline 9 & ماهية عقود التجارة الدولية & المبحث التمهيدي \\
\hline 20 & الاعفاء من المسئولية الناجمة عن الإخلال بينود عقود التجارية الدولية & المبحث الاول \\
\hline 23 & اعتبار فيرس كورونا المستجدعائق أمام تنفيذ عقود التجارة الدولية & 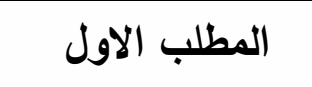 \\
\hline 36 & عدم إمكانية التنبؤ بتعرض العالم لفيرس كورونا وقت توقيع عقود & 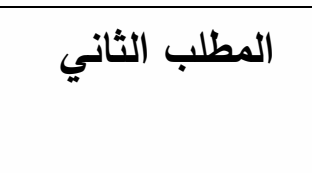 \\
\hline 45 & أثر اعتبار فيرس كورونا عائق امام تنفيذ عقود التجارة الدولية & المبحث الثاني \\
\hline 47 & إعادة التفاوض بشأن بنود عقود التجارة الدولية & 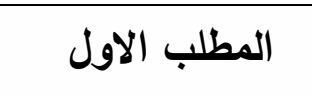 \\
\hline 57 & إنهاء عقود التجارة الدولية لإنتشار فيرس كورونا & المطلب الثاني \\
\hline 65 & & الخاتمة \\
\hline 66 & & النتائج والتوصيات \\
\hline 68 & & 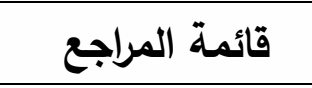 \\
\hline 75 & & الفهرس \\
\hline
\end{tabular}

تم بحمد اللهوتوفيقه ،،؛ 
